\title{
Archaeological Investigations on the Herd Ranch in Western Menard County, Texas
}

Jon C. Lohse

Follow this and additional works at: https://scholarworks.sfasu.edu/ita

Part of the American Material Culture Commons, Archaeological Anthropology Commons, Environmental Studies Commons, Other American Studies Commons, Other Arts and Humanities Commons, Other History of Art, Architecture, and Archaeology Commons, and the United States History Commons

Tell us how this article helped you.

This Article is brought to you for free and open access by the Center for Regional Heritage Research at SFA ScholarWorks. It has been accepted for inclusion in Index of Texas Archaeology: Open Access Gray Literature from the Lone Star State by an authorized editor of SFA ScholarWorks. For more information, please contact cdsscholarworks@sfasu.edu. 


\section{Archaeological Investigations on the Herd Ranch in Western Menard County, \\ Texas}

\section{Creative Commons License}

\section{(c) (1) (9)}

This work is licensed under a Creative Commons Attribution-NonCommercial 4.0 International License 


\section{Archaeological \\ Investigations on the Herd Ranch in Western Menard County, Texas}

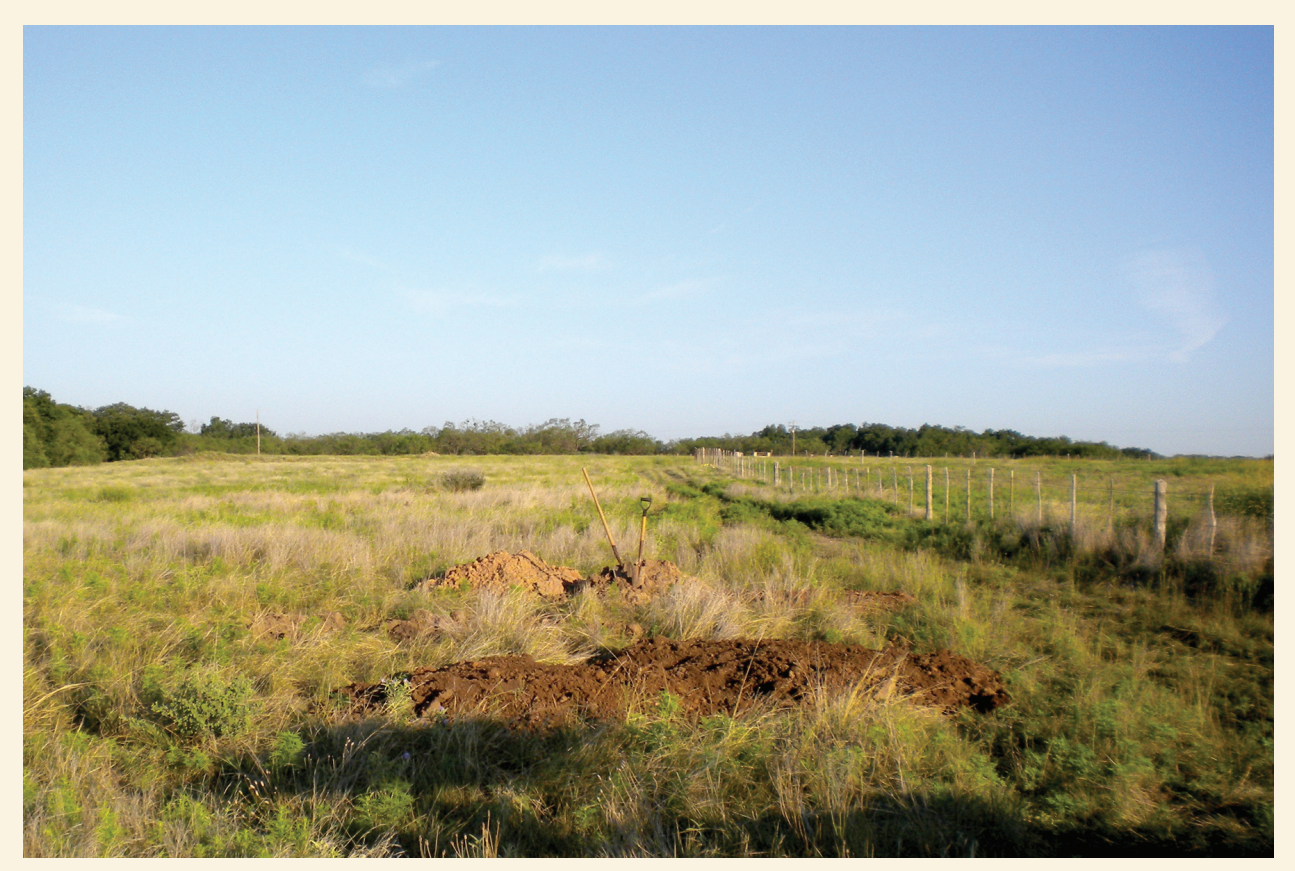

By Jon C. Lohse

With Contributions by Julian A. Sitters, David M. Yelacic, Cinda L. Timperley, and Sarah Scogin

Center for Archaeological Studies Texas State University-San Marcos San Marcos, TX 78666 www.txstate.edu/anthropology/cas/ Principal Investigator: Jon C. Lohse

TEXAS $*$ STATE。 UNIVERSITY The rising STAR of Texas 


\title{
Archaeological Investigations on the Herd Ranch in Western Menard County, Texas
}

\author{
by \\ Jon C. Lohse \\ With contributions by Julian A. Sitters, David M. Yelacic, Cinda L. Timperley, \\ and Sarah Scogin
}

Principal Investigator:

Jon C. Lohse

Archaeological Studies Report No. 19

Center for Archaeological Studies

Texas State University-San Marcos

2009 
1. Type of investigation: Survey with excavations of shovel tests and backhoe trenches

2. Project name: Archaeological Investigations on the Herd Ranch in Western Menard County, Texas

3. County: Menard

4. Principal Investigators: Jon C. Lohse

5. Published by the Center for Archaeological Studies, Texas State University-San Marcos, 601 University

Drive, San Marcos, Texas, 78666-4616 (2009)

Texas State University-San Marcos is a member of the Texas State University System Copyright (C) 2009 by the Center for Archaeological Studies at Texas State University-San Marcos

All rights reserved.

No part of this book may be reproduced or utilized in any form or by any means, electronic or mechanical, including photocopying, recording,

or by any information storage and retrieval system

without permission in writing.

For further information on this and other publications by

the Center for Archaeological Studies, please contact:

Center for Archaeological Studies

Texas State University-San Marcos

601 University Drive

San Marcos, TX 78666-4616

www.txstate.edu/anthropology/cas/

Editor: Brooke Boyer

Cover Photograph: Overview of C Herd, 41MN69, looking west.

Printed in the United States of America

by

Texas State University Print and Mail Services, Texas State University-San Marcos 


\section{Table of Contents}

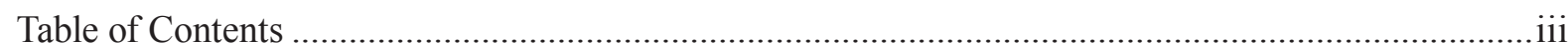

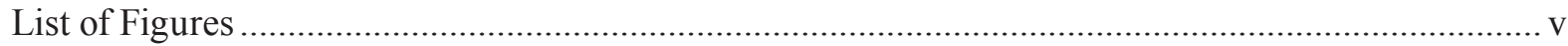

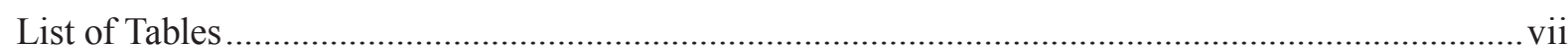

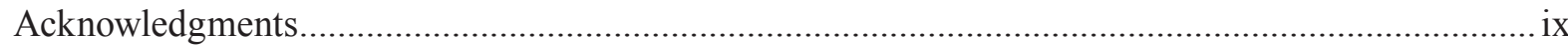

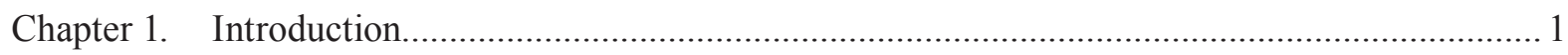

Chapter 2. Environmental and Cultural Background........................................................................ 5

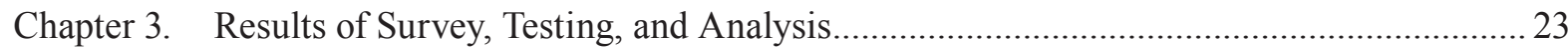

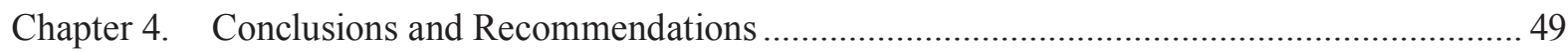

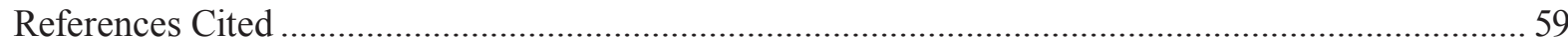




\section{List OF Figures}

1-1. Menard County, in west-Central Texas 2

2-1. Location of the Herd Ranch among Texas counties and environmental regions.......................... 6

2-2. PDSI variation in the past 975 years at two grid points in Central Texas ................................... 7

2-3. The broken and fluted base of a Clovis point, collected by Chesly Herd from along the San Saba River. 10

2-4. Angostura point fragments recovered from the Herd Ranch ..................................................11

2-5. Early Archaic point fragments recovered from the Herd Ranch .............................................. 12

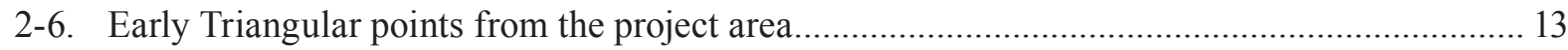

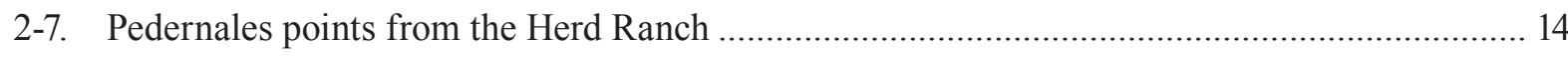

2-8. Marshall (A), Montell (B), and Marcos (C) points and point fragments previously collected

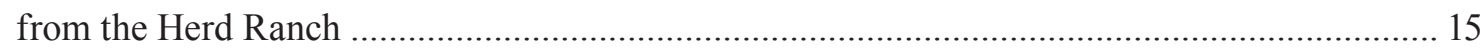

2-9. Side-notched Ellis and Fairland points from the study area .................................................... 16

2-10. Frio points recovered from the Herd Ranch by Chesly Herd.................................................... 17

2-11. Darl points characteristic of the very end of the Late Archaic recovered from the Herd Ranch

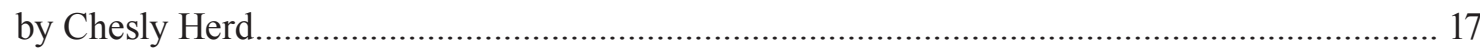

2-12. A well-made Alba point from the Herd Ranch....................................................................... 18

2-13. Perdiz points recovered from the Herd Ranch......................................................................... 19

3-1. Locations of each of the twelve sites recorded on the Herd Ranch in 2009 .............................. 23

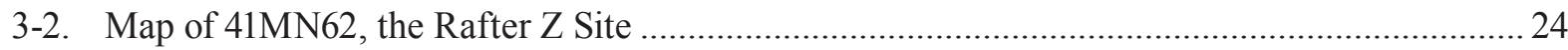

3-3. Z Herd, 41MN62, site overview looking northeast................................................................. 25

3-4. Ground exposure at 41MN63 showing bedrock outcropping through thin, upland soils........... 25

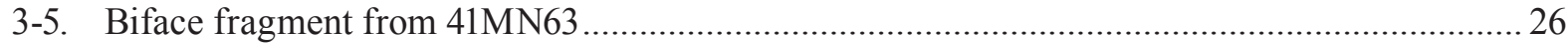

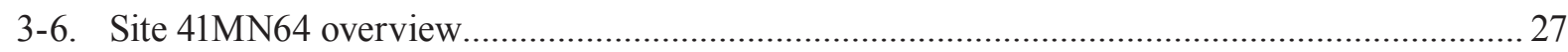

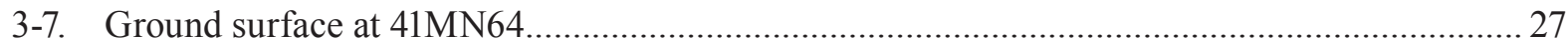

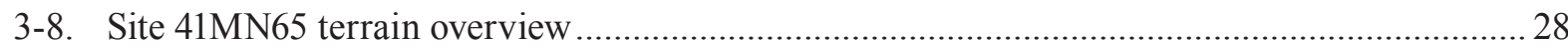

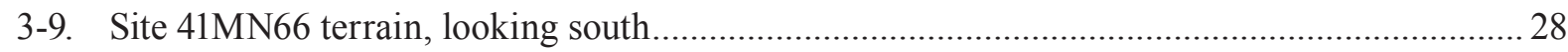




\section{List Of Figures (Continued)}

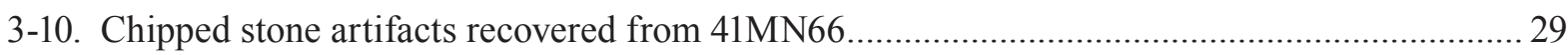

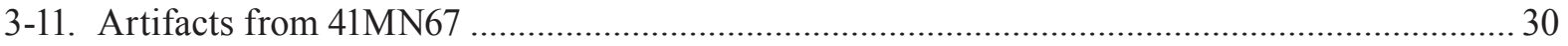

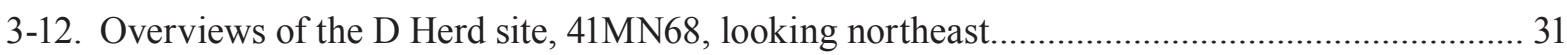

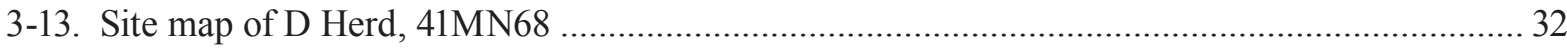

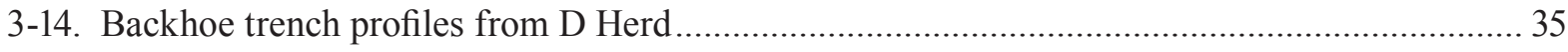

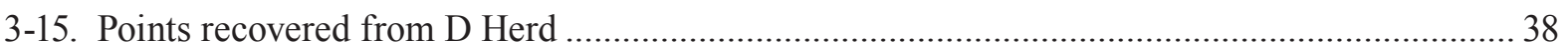

3-16. Bifaces, broken in manufacture, from Trench 1, Lv. 1 (A), Trench 4, Lv. 2 (B), and

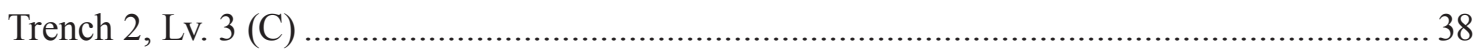

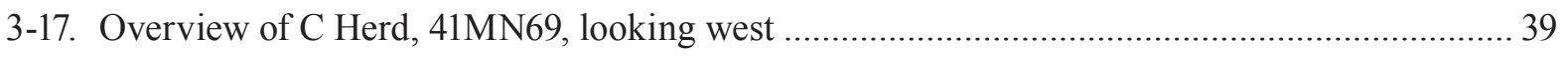

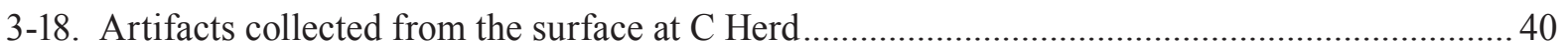

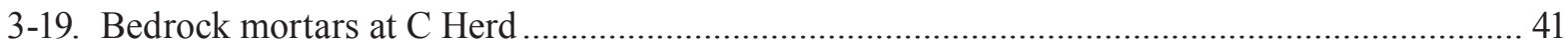

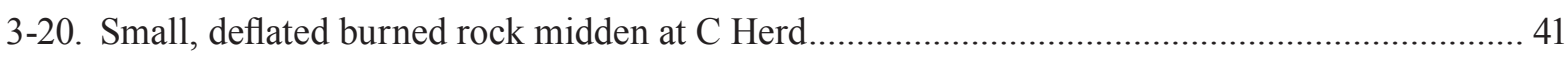

3-21. Map of C Herd showing site boundaries, and feature and backhoe trench locations.................. 42

3-22. Reconstructed cross section of backhoe trenches at C Herd ...................................................... 43

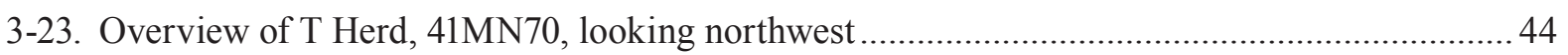

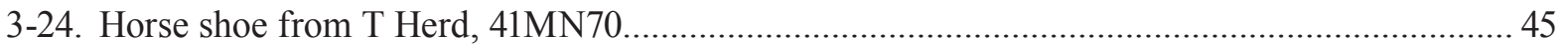

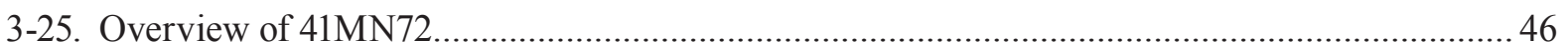

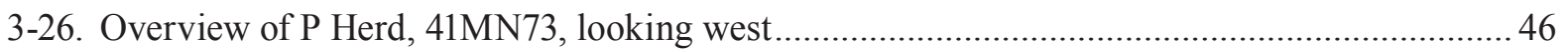

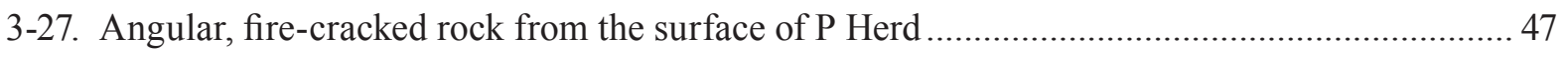

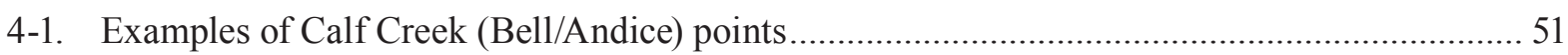

4-2. Index of cross-cultural participation in certain tasks by sex ...................................................... 55 


\section{LIST OF TABLES}

2-1. Generalized cultural chronology for the greater Central Texas region ..................................... 8

3-1. Inventory of Faunal Material Recovered from 41MN68, D Herd Site ...................................... 33

3-2. Habitats in which fauna from D Herd are commonly found ..................................................... 34

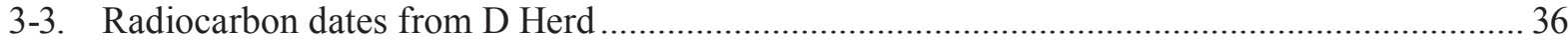

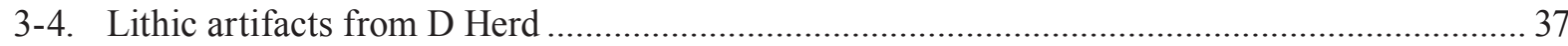





\section{ACKNOWLEDGMents}

This field work was carried out by Julian A. Sitters, Sarah Scogin, Spencer LeDoux, and Jon C. Lohse. Mr. Sitters and Ms. Scogin, along with David M. Yelacic and Cinda L. Timperley, contributed portions of this report, and Brooke Boyer assisted with the technical editing and formatting. Accommodations while this survey and testing was carried out were graciously provided by Dan Herd.

The Center for Archaeological Studies, Texas State University-San Marcos sincerely appreciates the opportunity to work with the Herd family and on their property in western Menard County. It is a rare and precious opportunity to work with both an impressive array of archaeological data, and also with sponsors who share a deep, abiding, and informed concern for the cultural and historical legacy of the state. Were more land owners of like mind, the collective understanding of history and prehistory in Texas would be substantially improved. 



\section{Chapter 1}

\section{INTRODUCTION}

In the summer of 2009, the Center for Archaeological Studies at Texas State University (CAS) conducted an archaeological survey and limited testing of portions of the Rafter Z Ranch and Saba Ranch (collectively referred to as the Herd Ranch) in western Menard County, Central Texas. This work was privately funded by the Herd family, who has long maintained a sincere interest in identifying, understanding, and preserving the very many historic and prehistoric resources on their property. The Herd Ranch is located along the north bank of the San Saba River, due east of historic Fort McKavett and approximately 20 miles west of the town of Menard, Texas (Figure $1)$.

The property has been held in the Herd family for decades. As such, a number of sites are to be found here that are in fair to remarkable states of preservation. Together, these represent an enormous span of time, from perhaps the very beginnings of Pleistocene human occupation in Central Texas, through the long Holocene era, and including Spanish colonization, pre- and post-Civil War United States activity, and early20th century rural farming and development.

This report presents the results of the CAS survey, as well as limited test excavations at two sites. In all, twelve sites were recorded, representing a variety of primarily prehistoric adaptations to both upland and lowland resources that are found in different parts of the San Saba River Valley. These data represent only a fraction of the overall record of previous human activity, occupation, adaptation, and labor that is present in the upper San Saba drainage. Additional limitedscale survey that has been conducted slightly downstream (Arnn 2007), has also identified a number of sites that, collectively, begin to convey information about discrete social groups that lived here in the prehistoric past. Because hunter-gatherers like those who occupied the San Saba Valley were residentially mobile, living in different places by season throughout the year as available resources were depleted, compiling multiple-site data sets such as these is important to reconstructing the social systems that define these areas.

At the present state of understanding, only basic descriptions of what was going on during some periods in the past can be offered. Much additional work is needed before detailed narratives can be presented or specific topics identified, although some issues have begun to emerge from the data are available. One involves what appears to be a highly specified pattern of labor allocation, where specialized task groups carried out a rather limited range of activities at certain sites. Another involves correlating periods of occupation with regional environmental and climatic variability. Given the rich historical record of the San Saba Valley (see below), another possible direction for future research would include focusing on the period of late Prehistoric contact between indigenous peoples of the region and the first European immigrants, chiefly Spanish 

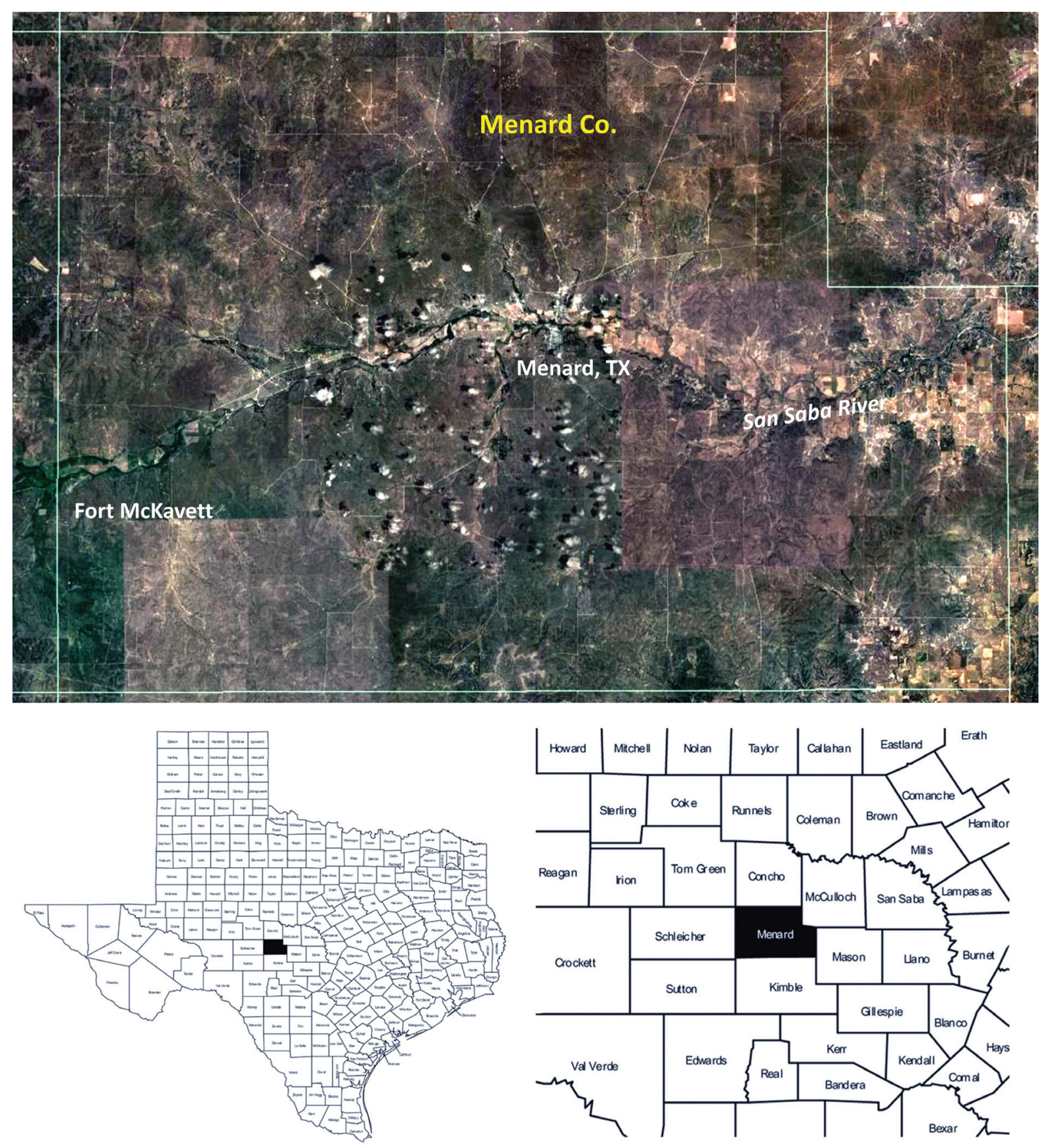

Figure 1. Menard County, in west-Central Texas. The study area is immediately north of the "Fort McKavett" label in the aerial image.

missionaries, soldiers, and economic speculators. The information presented in this report barely scratches the surface of what remains to be understood; a great deal more can be learned of the region through systematic, controlled archaeological and historical investigation.
In terms of report organization, Chapter 2 presents an overview of the regional history and environmental setting. Relative to other regions of the state, little previous archaeological work has been done in Menard County, yet significant cultural resources are present here. These include historic Ft. McKavett, the largest and perhaps 
best preserved of the frontier forts established by the United State Government to protect settlers from Indian raids and hostilities (not to mention the general lawlessness of the western frontier before and following the Civil War), and to keep safe the road linking San Antonio and El Paso. Closer to Menard, to the east, is the Presidio San Sabá, established by the Spanish in the eighteenth century (1757) to protect the newly established Mission Cruz de San Sabá (Walter et al. 2003). The mission itself, a highly significant historical landmark that links Central Texas with Spain's colonial New World empire, has recently been rediscovered approximately five miles east of Menard (Hindes et al. 1995). Finally, spread across the county is an untold number of unrecorded, and a few recorded, Native American sites representing millennia of occupation (Arnn 2007; McWilliams and Boyd 2008; Miller et al. 2003). Taken in whole, few parts of Texas can boast of such a rich cultural legacy.

Chapter 3 presents the finding of the 2009 CAS investigations. Narrative descriptions of each of the twelve sites that were recorded are presented, as well as brief discussions of their environmental setting and interpretations of their potential significance in regional context. The amount of data available from each site varies substantially; all sites were surveyed and inspected from the surface, while shovel tests were excavated in some sites where soil depths warranted. In two cases, 41MN68 and 41MN69, the D Herd and C Herd sites, backhoe trenches were excavated to investigate buried deposits. Naturally, information from these sites is far better developed than for the others.

The final chapter of this report presents a summary overview of these findings, suggests some possible directions that future study might consider, and makes recommendations for the future treatment of these important resources.
Before this project was undertaken, only 61 sites had been officially recorded by archaeologists in Menard County; the current effort increased this number by almost $20 \%$. These are very low numbers considering the significance of the known historic resources that are present, as well as the time depth of prehistoric occupation that is documented for the region. On this basis alone, one general conclusion of this work is that an adequate context within which to evaluate the potential importance or significance of recorded sites is currently lacking. Another important conclusion, drawn from the findings of the current project and supplemented by previous research, is that certain periods in the region's prehistoric, not to mention historical era, appear strongly represented. The implication is that what might be considered the Upper San Saba River drainage most certainly contains important information at a meaningful scale concerning discrete prehistoric groups who lived here. 


\title{
Chapter 2
}

\section{Environmental and Cultural Background}

\author{
Jon C. Lohse and David M. Yelacic
}

The project area is located along the north side of the upper San Saba River. Ranch to Market Road 864, which follows the river until it reaches the town of Menard, bisects a small portion of the project area. The study area is dynamic in terms of both environment and culture history. Understanding each helps evaluate the cultural record of the region in better context.

\section{Environmental Setting}

Environmental settings, which consist of but are not limited to components including geology, soil, climate, vegetation, and wildlife, play an important role in the attraction of human inhabitants as well as in site formation processes. Accordingly, these factors are taken into consideration when performing archaeological research. The Herd Ranch is located along the western border of Menard County on the Edwards Plateau, which was uplifted 10 to 20 million years ago during the Miocene epoch (Spearing 1991). The Edwards Plateau is bound to the south and east by the Balcones Escarpment, to the north by the Llano Estacado and the Rolling Plains, and to the west by the Pecos River and the mountains of West Texas (Figure 2-1).

Geologic deposits within the Herd Ranch are Holocene Alluvium (Qal), Pleistocene Fluviatile terrace deposits $(\mathrm{Qt})$, lower Cretaceous limestone and dolostone Fort Terrett Member (Kft), and
Lower Segovia Member/Upper Fort Terrett Member undivided (Ksf) (Bureau of Economic Geology 1981). Qal and Qt were both formed by fluvial (stream) processes and are both composed of sediments similar in character (e.g., varying proportions of gravel, sand, silt, and clay). The difference between the two geologic units is time: Qal represents recent or ongoing deposition, whereas Qt represents ancient fluvial regimes. $\mathrm{Kft}$ and Ksf are deposits of the warm, shallow seas that once occupied Central Texas. Both Kft and Ksf are composed of impure limestones and dolomites, but Kft also contains chert, a material that was commonly used by prehistoric and historic Native Americans to make tools.

Described by Coffee (1967), soils that have formed atop and within the geologic deposits on the Herd Ranch include Dev Soils (Ds); Frio clay loam, 0 to 1 percent slopes ( $\mathrm{FcA})$; Kavett silty clay, 0 to 3 percent slopes (KaB); Knippa silty clay, 0 to 2 percent slopes (KpA); Tarrant soils, undulating (Ta); Tarrant-Brackett association, hilly ( $\mathrm{Tb}$ ); Tarrant-Kavett complex, nearly level (Tk); Uvalde silty clay loam, 0 to 1 percent slopes (UaA); Uvalde silty clay loam, 1 to 3 percent slopes (UaB); and Valera silty clay, 0 to 3 percent slopes (VaB). These technical classifications correspond with landform and depositional context: Ds and FcA soils are deep and found near stream channels in floodplain settings; KpA, $\mathrm{UuA}$, and $\mathrm{UuB}$ are moderately deep and found on terraces; and $\mathrm{KaB}, \mathrm{Ta}, \mathrm{Tb}, \mathrm{Tk}$, and $\mathrm{VaB}$ are thin soils found in gently sloping to nearly level upland 


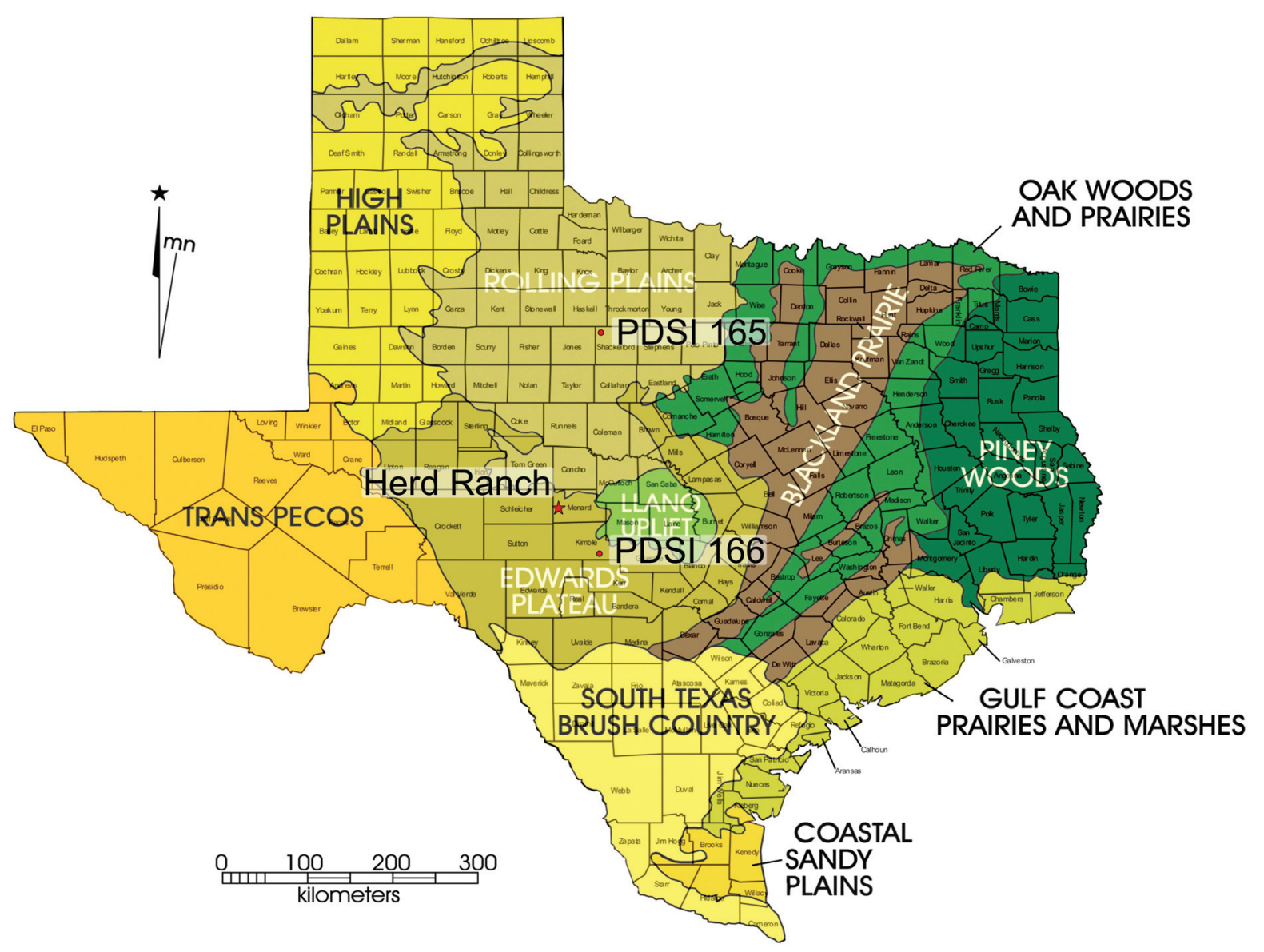

Figure 2-1. Location of the Herd Ranch among Texas counties and environmental regions. PDSI locations are used for paleoclimatic reconstructions (see below).

settings, valleys, and side slopes. Where soils are deep, there is a potential for intact cultural deposits to be buried, and where soils constitute only a thin veneer, barely covering bedrock, there is little potential for cultural materials to be stratigraphically separated.

Menard County is characterized as having a subtropical/semiarid climate dominated by warm, dry weather (Coffee 1967; Tyler 2006). Based on a thirty-year record (1951-1980) in nearby Junction, summers have mean maximum temperatures approaching $94^{\circ} \mathrm{F}$ and winters have mean minimum temperatures near $35^{\circ} \mathrm{F}$ (Bomar 1983). At 22.52 inches, mean annual precipitation in Junction is slightly lower than the mean annual precipitation on the Greater Edwards Plateau,
23.52 inches. Precipitation in Menard County is bimodal, with most precipitation occurring in the late spring and in the early fall (Bomar 1983; Coffee 1967).

Soils and climate of the Edwards Plateau provide the conditions necessary for a mosaic of woody vegetation, including live oak, shinnery oak, junipers, mesquite, and savannah/grasslands, which commonly consist of switchgrass, bluestems, gramas, Indiangrass, wildrye, curly mesquite, and buffalograss (Gould 1962). As described by Blair (1950), typical modern fauna of the region include white-tailed deer, eastern cottontail, raccoon, opossum, and badger as well as myriad other species. In historic and prehistoric times, bison were also present, and were relied 
upon quite heavily during periods when they were abundant (Mauldin et al. 2009).

Environments of the distant past were just as influential on human inhabitants as they are today. As ancient conditions cannot be directly observed, paleoenvironmental reconstructions often rely on proxy measures. Paleoenvironmental proxies do not directly reflect past environments, but rather they can be used to infer characteristics of past environments (Ellis et al. 1995). Using the Palmer Drought Severity Index, for example, Mauldin et al. (2009) conclude that weather patterns over the last 1000 years grew increasingly volatile, with brief periods of heavier-than-normal rainfall interrupted by exceedingly dry conditions. The Palmer Drought Severity Index (PDSI) is a mathematical model of soil moisture based on historical records of precipitation and temperature, and it is commonly used by the agriculture industry as an index of drought. Essentially, the Index indicates the degree of variance between wet and dry conditions; relatively flat parts of the graph represent long periods of relatively even or constant rainfall, even if such precipitation is light (indicating more drought and represented by a higher Index score). Volatile changes in the graph indicate extreme changes between localized precipitation and aridity (Figure 2-2).

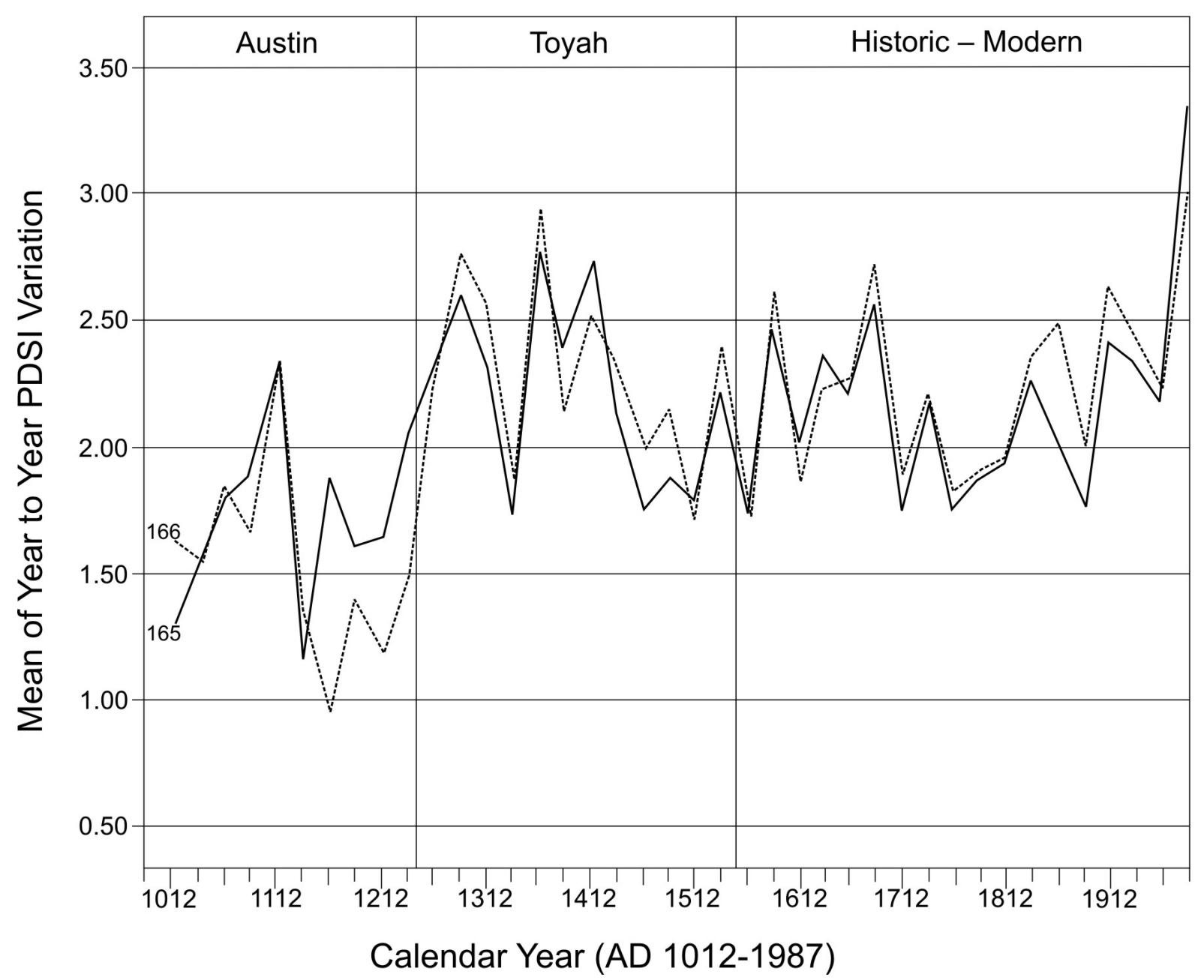

Figure 2-2. PDSI variation in the past 975 years at two grid points in Central Texas (see Figure 2-1; adapted from Mauldin et al. 2009). See Cultural Chronology section, below, for discussion of Austin and Toyah intervals. 
Recent research has correlated a grid of dendochronologies (local chronologies based on tree rings) with PDSI to extrapolate drought conditions in the United States for up to the past 1000 years (Alley 1984; Cook et al. 1999), rendering the model useful for somearchaeologists dealing with this span of time. Through PDSI and gridded dendrochronological proxy data, Mauldin et al. (2009) have suggested that the availability of bison as a local food source for indigenous peoples became increasingly erratic in the last 1000 years, mirroring localized precipitation and mesic (moist) versus xeric (dry) conditions. One can easily think of this pattern as increasingly localized or "patchy" weather conditions during an extended period of overall increasing drought. This increase in variation is certain to have had important implications for human groups who relied heavily on resources that required steady access to water.

\section{Cultural Chronology}

The cultural chronology for the western part of Central Texas is not completely understood, and is not likely to be in the near future. Archaeologists have broken the several-millennia-long period of time before the arrival of Europeans (the Prehistoric period) into three main blocks of time, the Paleoindian, the Archaic, and the Late Prehistoric (Table 2-1). From across Central Texas, a number of deposits are known that indicate rich and prolonged cultural developments dating from as early as approximately 13,500 calendar years

Table 2-1. Generalized cultural chronology for the greater Central Texas region. Finer subdivisions are known for localized sequences, and important cultural manifestations are reported in some cases but are not indicated here. Artifact types in bold have been recovered from the Herd Ranch.

\begin{tabular}{|c|c|c|c|}
\hline Epoch & Period & $\begin{array}{c}\text { Age (in years } \\
\text { Before Present) }\end{array}$ & Some Diagnostic Artifact Types \\
\hline \multirow{11}{*}{ 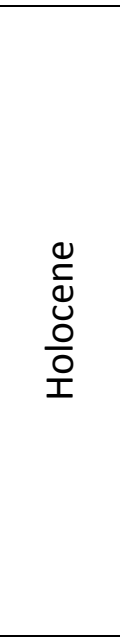 } & Historic & $\sim A D 1550$ & European wares, metal tools \\
\hline & Late Prehistoric: Toyah & $700-\leq 300$ & PERDIZ \\
\hline & Late Prehistoric: Austin & $1,200-700$ & ALBA, Scallorn, Edwards \\
\hline & Late Archaic III & $1,700-1,200$ & DARL, Ensor, FaIRLAND, FrIo, Ellis \\
\hline & Late Archaic II & $3,400-1,700$ & $\begin{array}{l}\text { Castroville, MARCos, MONTELL, } \\
\text { MARSHALL }\end{array}$ \\
\hline & Late Archaic I & $4,000-3,400$ & Bulverde, Pedernales \\
\hline & Middle Archaic II & $4,500-4,000$ & Nolan, Travis \\
\hline & Middle Archaic I & $5,600-4,500$ & EARLY TRIANGULAR \\
\hline & Early Archaic III & $6,800-5,600$ & MARTINDALE, Bandy, Uvalde \\
\hline & Early Archaic II & $8,000-6,800$ & Gower, Hoxie, Jetta \\
\hline & Early Archaic I & $8,800-8,000$ & ANGOSTURA \\
\hline \multirow{2}{*}{ 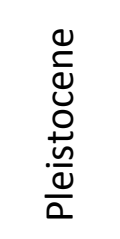 } & Late Paleoindian & $10,200-8,800$ & $\begin{array}{c}\text { Golondrina, Scottsbluff, Barber, } \\
\text { St. Mary's Hall }\end{array}$ \\
\hline & Early Paleoindian & $11,500-10,200$ & Clovis, Folsom, Midland \\
\hline
\end{tabular}


ago (the beginning of the Clovis era) or earlier, until the establishment of Spanish, French, and Anglo settlements across the region prior to AD 1600. Shorter intervals in these long periods are defined principally by time-diagnostic artifact types, but also by other cultural developments, population trends, and to a lesser degree, by important environmental variation. Because artifact styles overlap in age, are prone to change slowly over time, and often come from sites with extended sequences that are not always finely resolved, accurately reconstructing regional phases is not always possible, or is possible only to a degree. Still, important syntheses for regional sequences have been presented by Steve Black (1995), Tom Hester (1995, 2004), and Michael Collins (1995, 2004), among others (Prewitt 1981, 1983; Weir 1976).

\section{Paleoindian}

The Paleoindian period is frequently divided into Early (11,500-ca. 10,200 BP) and Late $(10,200-8800$ BP) periods. The Early Paleoindian period is traditionally understood to have been comprised of highly nomadic cultures that relied heavily on hunting large game animals (Black 1989). Recent research suggests that Early Paleoindian subsistence patterns were considerably more diverse than previously thought, and included reliance on local fauna including turtles, rodents, lagomorphs (rabbits and hares), and other small- and medium-sized game (Black 1989; Bousman et al. 2004; Collins and Brown 2000; Lemke and Timperley 2008; see Byers and Ugan 2005; Cannon and Meltzer 2004; Waguespack and Surovell 2003). New models describing Early Paleoindian diet and related activities are slowly accommodating both regional variability in prey choice and functional differences between sites from which subsistence data are collected. Additionally, since hunting large game is strongly associated with male labor cross culturally (Murdock and Provost 1973), these new studies are examining how certain individuals may have engaged in hunting large game in the capacity of specialists while other individuals carried out more generalized foodgetting activities focusing on broad spectrums of diet choice (e.g,. Lohse 2009).

In Central Texas, the Early Paleoindian period is associated with the Clovis and Folsom archaeological cultures, meaning that the material traits that define these time periods were shared widely across enormous areas; no widely shared affiliation in terms of language or ethnic identity is recognized by archaeologists. Diagnostic items include fluted, lanceolate-shaped projectile points. Midland points, which are coeval with and slightly younger than Folsom are unfluted. Clovis is also characterized by well-made prismatic blades (Collins 1995; Green 1963), and both Clovis and Folsom have exquisitelymade bifaces and tools-on-bifaces. While the perception of Clovis diet is steadily changing to include a broader range of prey, Folsom peoples are considered to have focused more narrowly, though not exclusively, on Pleistocene bison, Bison antiquus (a larger, now-extinct forbearer of contemporary bison, Bison bison). The base of a fluted Clovis point was collected from along the north bank of the San Saba River, indicating that Early Paleoindians were in the study area by at least ca. 13,500 years ago (Figure 2-3).

The Late Paleoindian subperiod occurs from ca.10,200-8800 BP. Reliable evidence for these dates was recovered from the Wilson-Leonard site, north of Austin (Bousman et al. 2004; Collins 1998). At Wilson-Leonard, archaeologists excavated an occupation known as Wilson, named for the unique corner-notched projectile point. The dense occupation also included a human burial (Bousman et al. 2004; Collins 
1998). In addition to the Wilson occupation, Golondrina-Barber and St. Mary's Hall components, dating between 9500 and 8800 BP, were excavated. Collins (1995) suggests the Wilson, Golondrina-Barber, and St. Mary's Hall components represent a transitional period between the Paleoindian and Archaic Periods due to the faint presence of notched projectile points and burned-rock cooking features. Based on excavated remains from Baker Cave, in

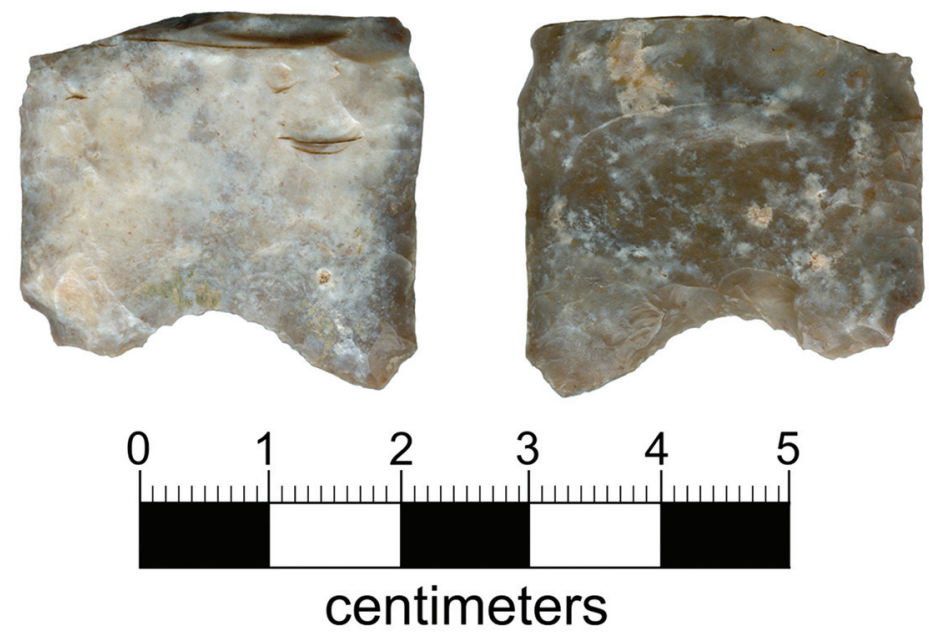

Figure 2-3. The broken and fluted base of a Clovis point, collected by Chesly Herd from along the San Saba River. the Lower Pecos region (Hester

1983), at least some Late Paleoindians also relied on a broad suite of plant and animal resources.

\section{Archaic}

The Archaic in Central Texas lasted approximately 7500 years, from 8800-1200/1300 $\mathrm{BP}$, and is commonly divided into Early, Middle and Late periods. The Archaic marks several important transitions from the preceding Paleoindian period: a shift in hunting emphasis from large to smaller game animals; an apparent increase in the use of plant resources for food, which involved grinding stones for processing nuts and seeds; development of diverse cooking technologies involving fire-heated rocks; increased use of organic materials for tool manufacturing and an increase in the number and variety of lithic tools for wood working; the predominance of corner- and side-notch projectile points; greater population stability and less residential mobility; and systematic burial of the dead. Clearly, the Paleoindian-to-Archaic transition involved dramatic, fundamental changes to how ancient people related to one another, both in terms of intra-group identity and between-group relations.

An aspect of large game hunting that characterized preceding times were frequent long distance treks to follow individual animals or game herds. These treks often took the people involved in them far from residential base areas, meaning that Paleoindian cultural patterns tended to be more "spread out" across the landscape. Archaic societies still wandered in the pursuit of food, but these territorial ranges were considerably smaller than before. In this sense, the Archaic might be thought of as a gradual "setting in" on the landscape. Inevitable consequences included increased territoriality, increased exploitation of more diverse resources, and new labor arrangements between members of the same social group. In terms of preliminary findings from the CAS survey of the Herd Ranch, divisions of labor between probable male and female-related tasks became evident in ways not seen in Paleoindian times. Specifically, this involved specialized features for processing plant foods as well as sources of protein that were collected from the nearby San Saba River. 

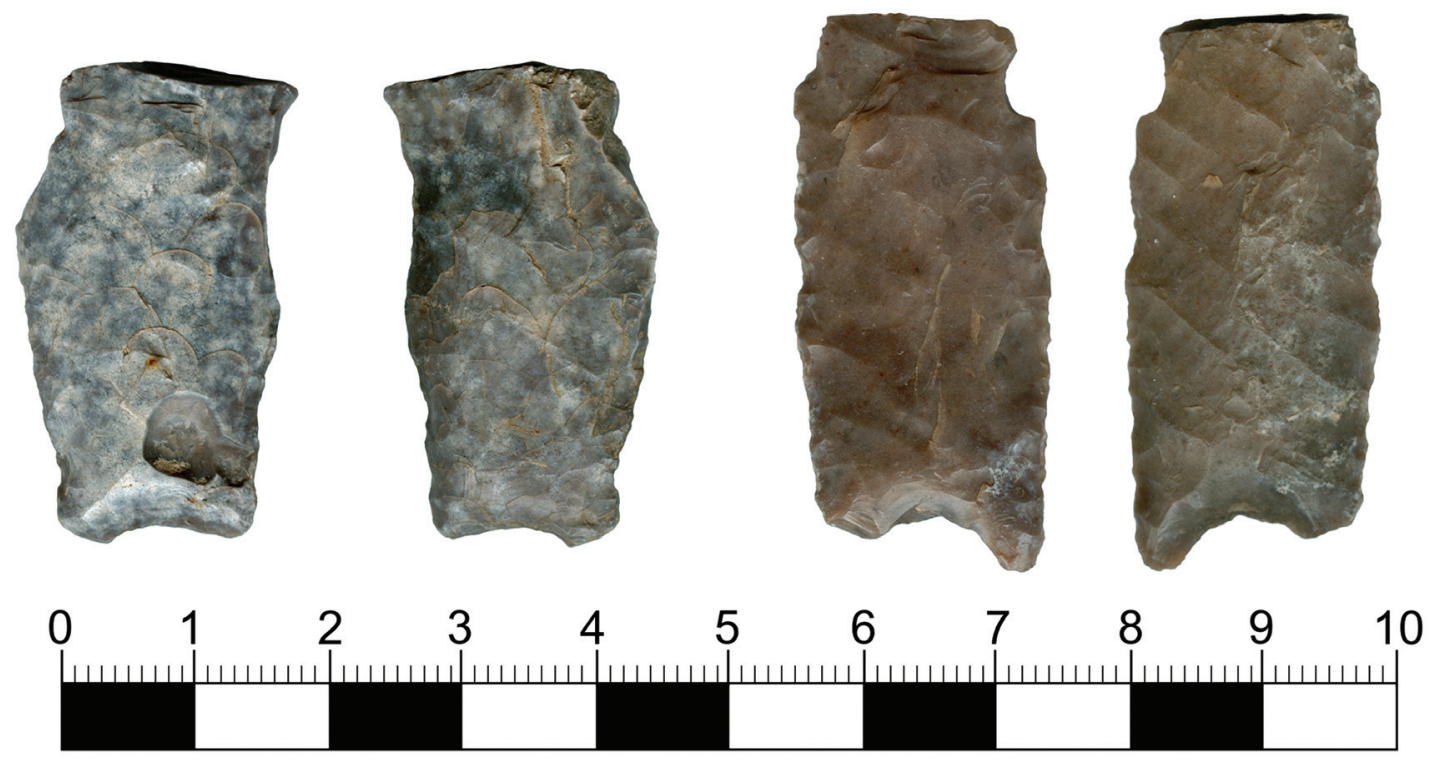

\section{centimeters}

Figure 2-4. Angostura point fragments recovered from the Herd Ranch. This type bears strong similarities with Late Paleoindian types, including lanceolate body shape and distinctive parallel-oblique flaking (visible on specimen at right).

\section{Early Archaic}

The Early Archaic extends from approximately 8800 to 5600 BP. This sequence follows Collins (1998), who uses the Angostura point type (Figure 2-4) to denote the beginning of the Early Archaic; other researchers place this key type at the very end of the Paleoindian period. Moreover, these dates are only provisional; local sequences and chronologies will differ, and dating of the latter portion of this period is notoriously imprecise (Houk et al. 2009). Significant changes occurred in stone tool technology: point bases transition from stemmed, to split stemmed, and then to corner notched (Figure 2-5), while distal or blade portions become increasingly triangular. Additionally, specialized tool forms, such as Clear Fork gouges and Guadalupe bifaces, appear. Special-purpose forms are present in earlier periods, but not to the same degree as in the Early Archaic. A change in diet, as evidenced by the increased number of ground stone artifacts and burned rock midden cooking features, distinguish this cultural period from previous ones (Collins 1995; Turner and Hester 1993:246256). A variable climate and concomitant variation in game resources, particularly bison, are related to the shift in subsistence activities, and Collins (1995) suggests that Early Archaic peoples aggregated in wetter portions of Central Texas.

\section{Middle Archaic}

The Middle Archaic coincides generally with the onset of the Altithermal, an extended period of exceedingly dry climate with erratic spikes in localized moisture. Because of the overall dry climate during this interval, Middle Archaic sites can be difficult to locate. Deposits that did accumulate were frequently washed or eroded away during subsequent rainfall, as regional 

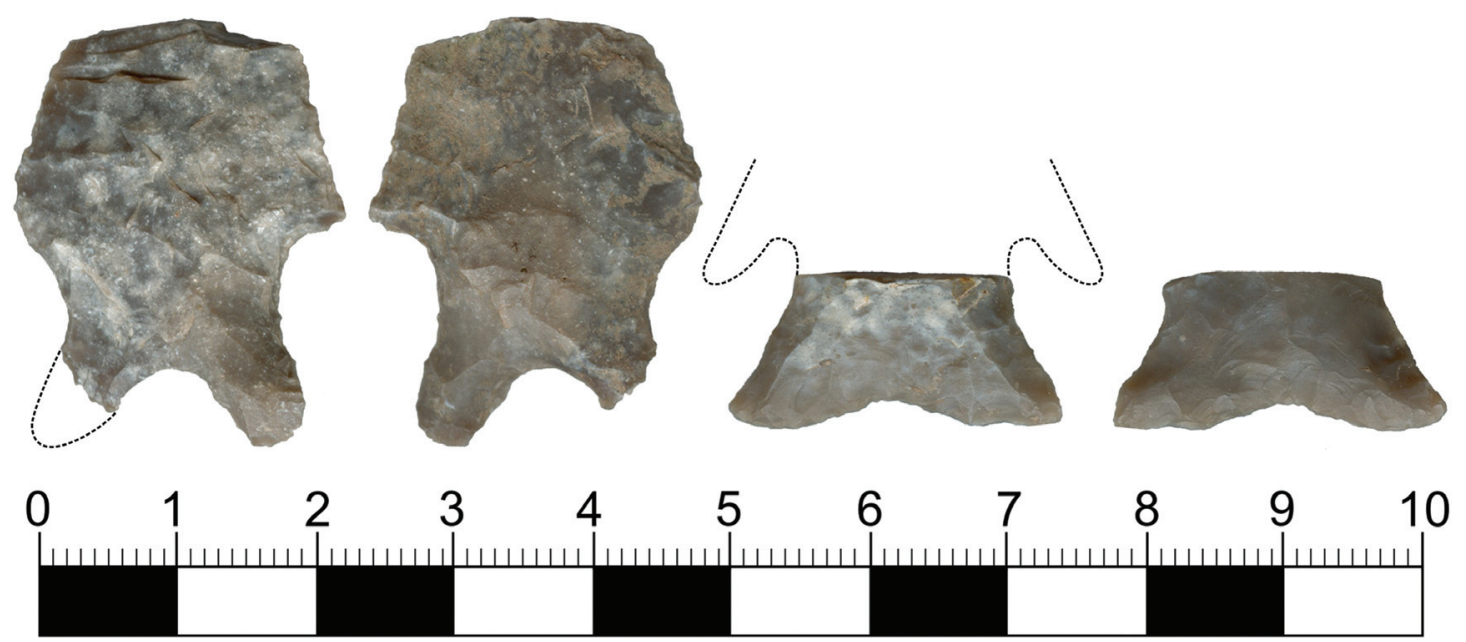

centimeters

Figure 2-5. Early Archaic point fragments recovered from the Herd Ranch. Specimen at left is a split-stem (or bifurcated stem) point, similar to Gower or Uvalde types. Specimen at right is corner-notched, and has recurved, shallowly notched base characteristic of the Martindale type. Martindale and similar points postdate Gower and Uvalde, though both are Early Archaic in age.

aridity left diminished ground cover to hold sediments and archaeological materials in place. Many Middle Archaic sites are therefore found near perennial sources of water, and in locations where geological strata remain intact. Vegetation and wildlife regimes all fluctuated in response to these environmental oscillations, with human groups responding accordingly.

The Middle Archaic, like other periods, is divided according to diagnostic projectile point styles. Some archaeologists, including Collins (1995), divide the Middle Archaic period into three intervals based on point styles: BellAndice-Calf Creek (hereafter called Calf Creek), Taylor (also Early Triangular), and Nolan and Travis. The Calf Creek interval was a mesic period when grasslands, attractive to bison herds, expanded southwards into Central and South Texas. Calf Creek materials are reported across the Southern Plains of the United States, from Kansas through Oklahoma and western Arkansas down to the Texas-Mexico border and along the Texas Gulf Coast. Calf Creek peoples are understood to have been intensively focused on bison exploitation; archaeologists in Oklahoma reported a spectacular bison skull, dating to ca. 5100 years ago, with a Calf Creek point still embedded in it (Bement et al. 2005). While Calf Creek materials have been reported from a large area, at least in Texas these items are nearly always associated with other kinds of distinctive artifact styles. Calf Creek sites are poorly dated in general (some exceptions exist), and to date not one isolated Calf Creek component has been reported from Texas. A possible exception is at the Richard Beene Site (41BX881) just south of San Antonio, where researchers recovered a small amount of Calf Creek material, mixed with a few other diagnostic artifacts, in soils dating to approximately $4100-4500$ years ago (Thoms and Mandel 2007). This age range is considerably younger, by at least 600 years, than the dated bison skull from Oklahoma, leaving open the question of Calf Creek chronology. Accordingly, this important interval is included in the current 
project chronology with other, apparently contemporary Middle Archaic materials, such as Early Triangular.

Early Triangular points, which here subsume the Taylor and Baird types, date from approximately 5600-4500 BP. These distinctive points were also used as knives, and stand out among regional types in that they show no notching whatsoever (Figure 2-6). Early Triangular forms were replaced by Nolan and Travis points (Collins 1995, 2004). The Nolan-Travis interval, which so far has not been identified on the Herd Ranch, was a period when temperature and aridity were at their peak. Prehistoric peoples acclimated to this dry climate through increased utilization of xerophytes such as sotol (Johnson and Goode 1994). These plants were typically baked in earth and rock-lined ovens; the repeated use of these facilities led to the localized accumulation of tons of burned and fire-cracked rock, representing one kind of burned rock midden.

\section{Late Archaic}

The Central Texas Late Archaic dates to approximately 4000-1250 BP (Collins 1995:384, 2004). This long span of time is defined by a host of point types, many of which strongly resemble one another and overlap considerably in age. In response, some archaeologists, like LeRoy Johnson and Glenn Goode (1994), observe only two major subdivisions of this period, Late Archaic I and Late Archaic II. Still, sites with ideal stratigraphic separation may reveal more than only these two intervals. Late Archaic I, according to Johnson and Goode (1994), is marked by two significant cultural traits: 1) the fine thinning by billet of bifacial knives and
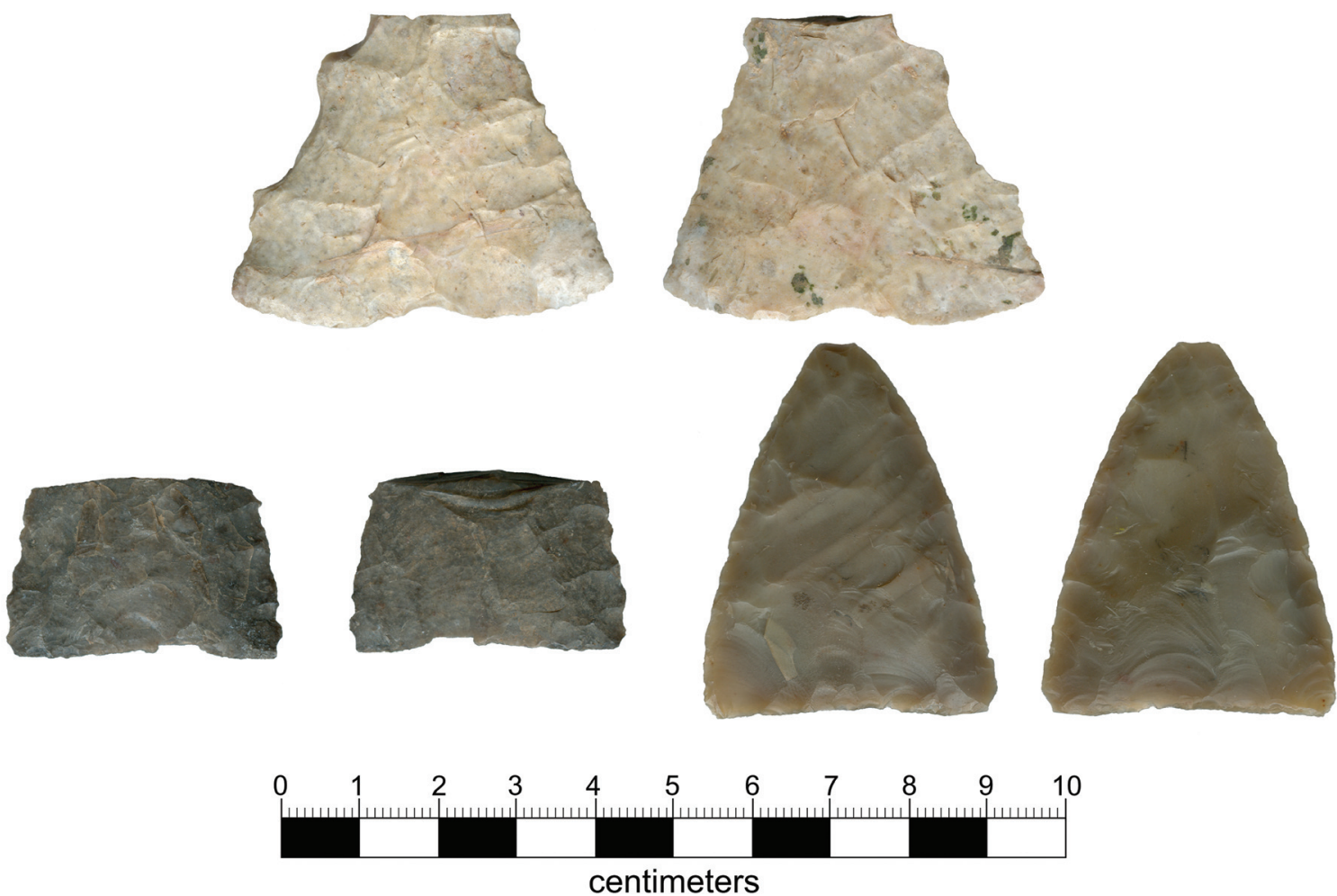

Figure 2-6. Early Triangular points from the project area. 
projectile points, and 2) the human population appears to have increased. If billet flaking is recognized as a characteristic of Late Archaic I, then the interval should be expanded to include not only broad-bladed Pedernales forms but also triangular-bladed Castroville, Marcos, and Montell (see Table 2-1). Pedernales points are perhaps the most common point types in the Central Texas Archaic, and often show drastic reworking all the way down to the stemmed base (Figure 2-7). The exceedingly wide variation in manufacturing technique and execution in these tools show that the manner in which they were used was for many different activities, they were
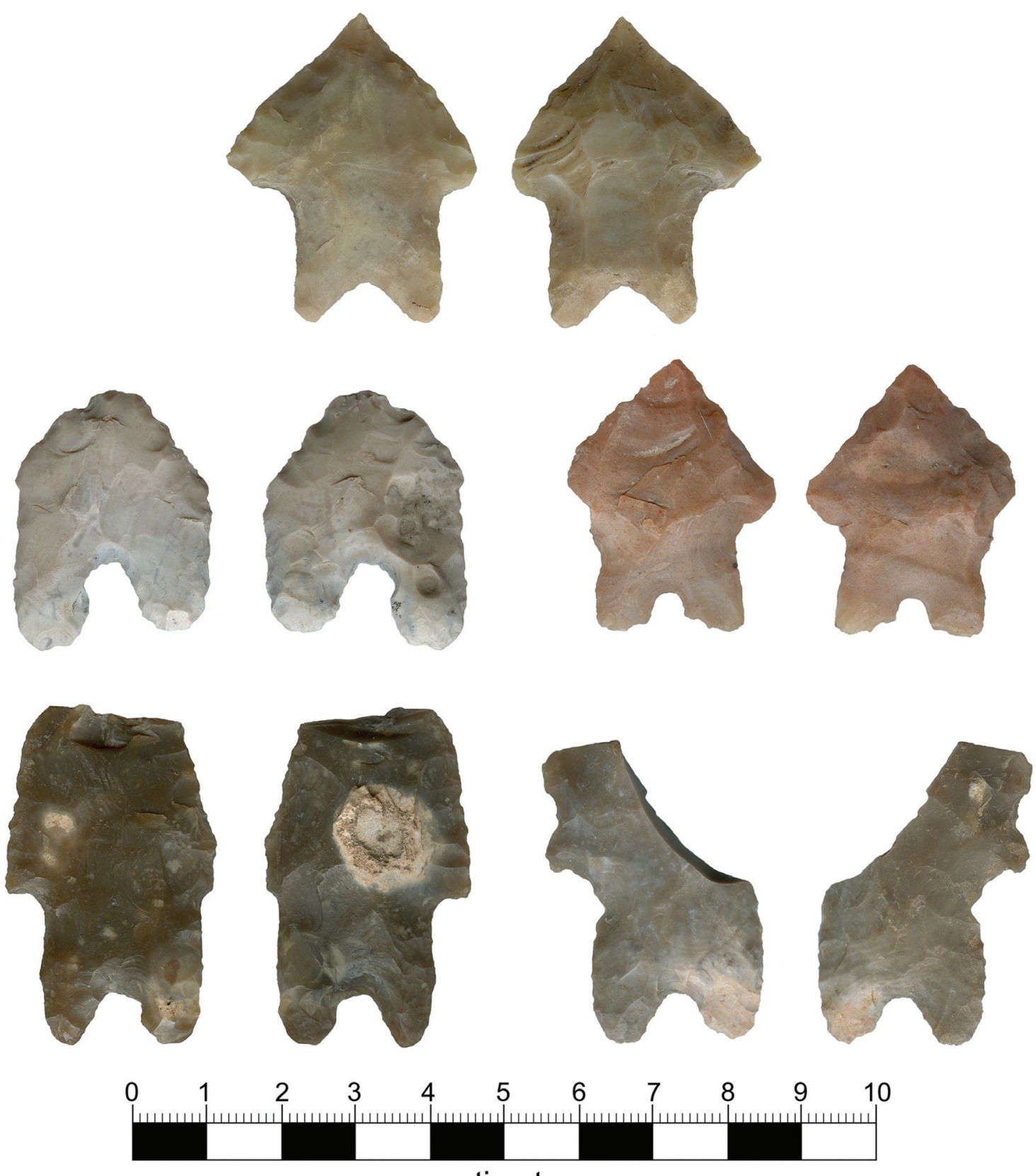

centimeters

Figure 2-7. Pedernales points from the Herd Ranch. Note the degree to which specimens in top two rows have been reworked. 
often kept in use long after initial breakage, and the fact that they are associated with female burials from this time, including at cemeteries like Ernest Witte (41AU36; Hall 1981), Loma Sandia (41LK28; Taylor 1995), and Zatopec (41HY163; Lohse 2010), suggests that the popularity of this form may be related to its manufacture and/or use
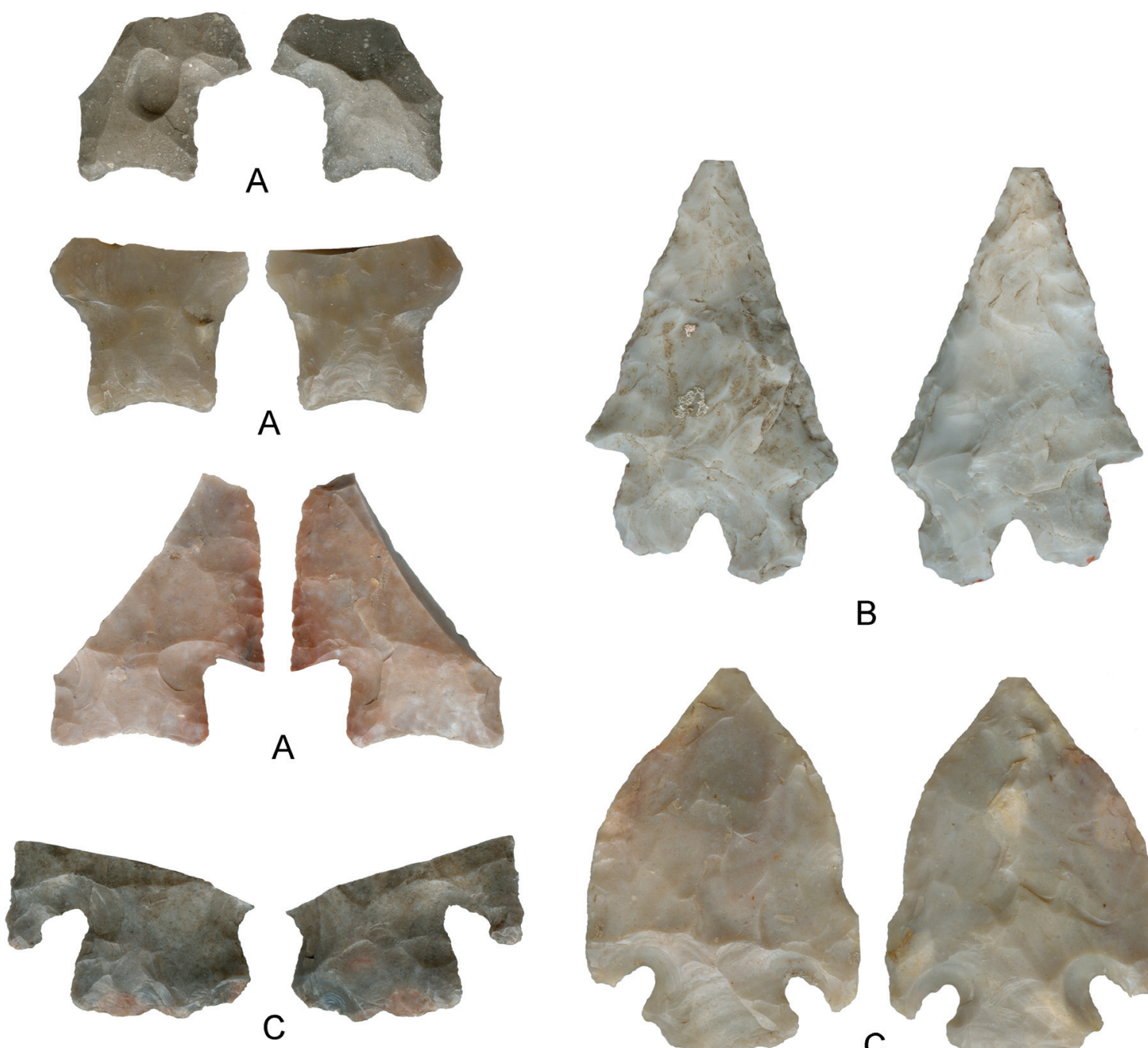

B
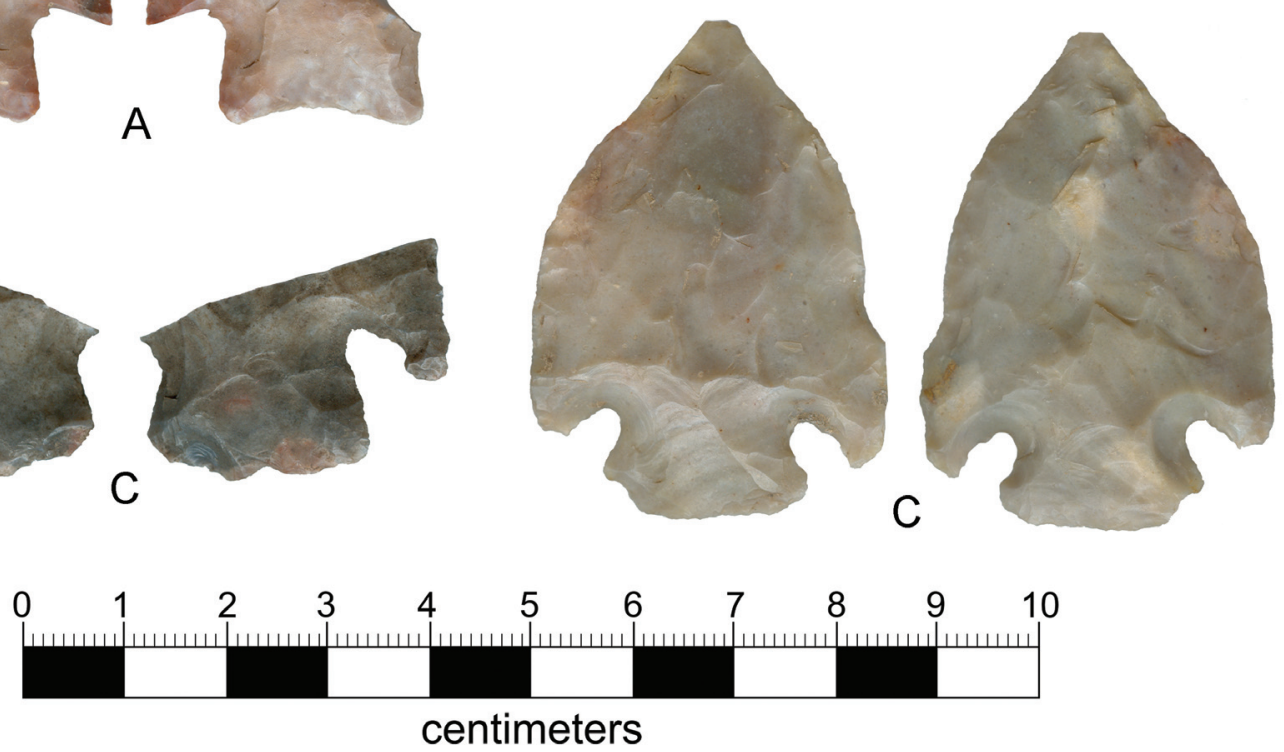

Figure 2-8. Marshall (A), Montell (B), and Marcos (C) points and point fragments previously collected from the Herd Ranch. These forms all post-date Pedernales. 
mesic (moist) climate through this part of the Late Archaic (Collins 1995; Johnson and Goode 1994; Mauldin et al. 2009). Mauldin et al. (2009) suggest that increasing climatic variation resulted in a general decrease in grassland bison range. Points types such as Castroville and Montell are commonly associated with bison, suggesting that these types were used in much the same manner as Calf Creek points.

The final part of the Late Archaic marks an important transition in many respects. Regional populations continued to increase, point types continued to proliferate, and territorialism, as indicated by the prevalence of cemeteries like Olmos Dam (Lukowski 1988) and Earnest Witte (Hall 1981), also appears to have increased. However, some other archaeologists challenge the interpretation of a growing population by citing a decrease in burned rock middens (Prewitt 1981:80-81). The most common diagnostic artifacts include a series of related types such as Ensor, Fairland, Frio, and Ellis (Figures 2-9, 2-10). Darl points, too, date to the end of the Late Archaic, but probably post-date these earlier types (Figure 2-11).

\section{Late Prehistoric}

Collins $(1995,2004)$ dates the Late Prehistoric in Central Texas at 1300/1200-300 BP, and follows Kelley (1947) in dividing it into Austin and Toyah components. The current project delineates the Austin period to $1250-750 \mathrm{BP}$ and the Toyah period to $750-300 \mathrm{BP}$. The most distinctive change from previous eras is that hunters no
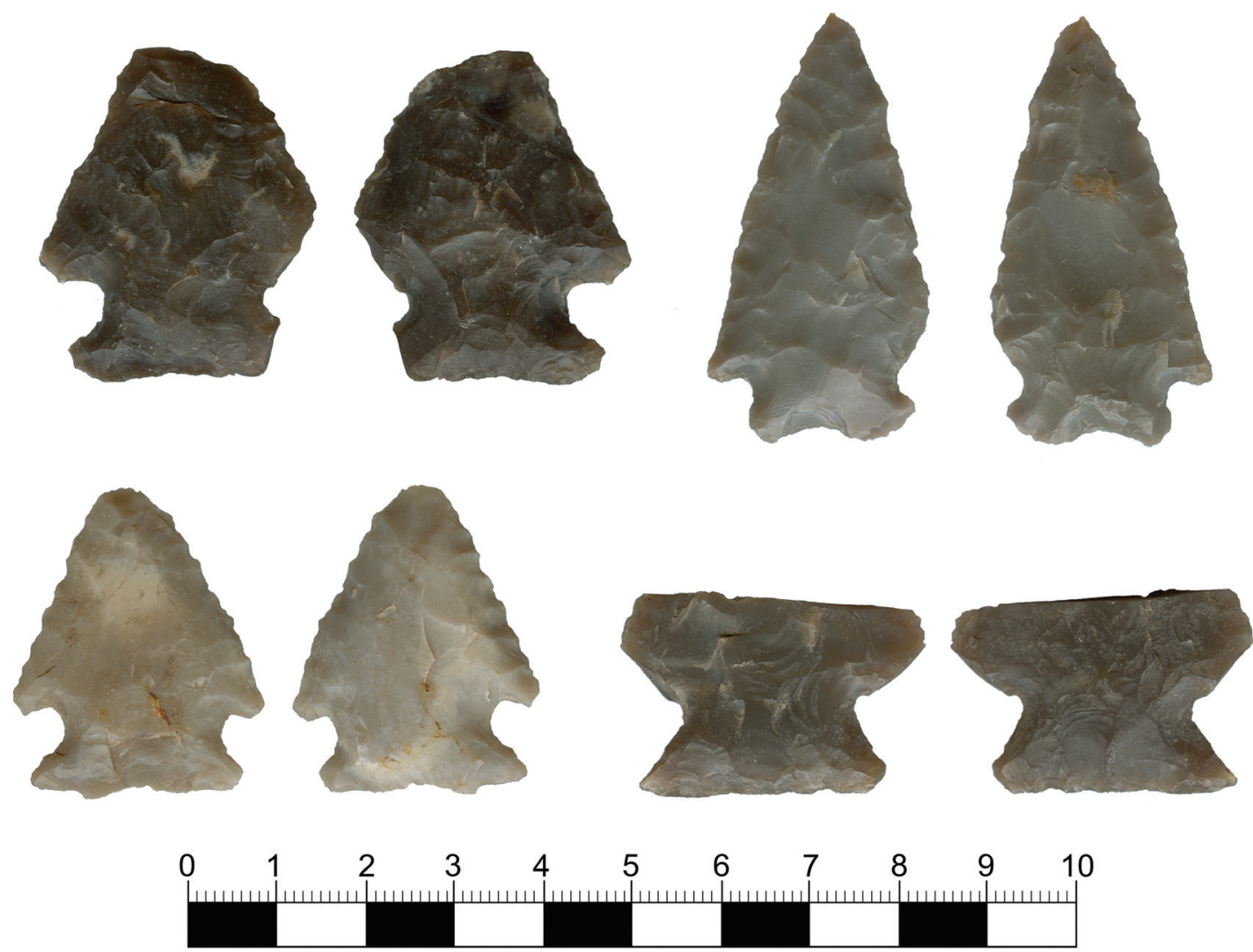

centimeters

Figure 2-9. Side-notched Ellis and Fairland points from the study area. 

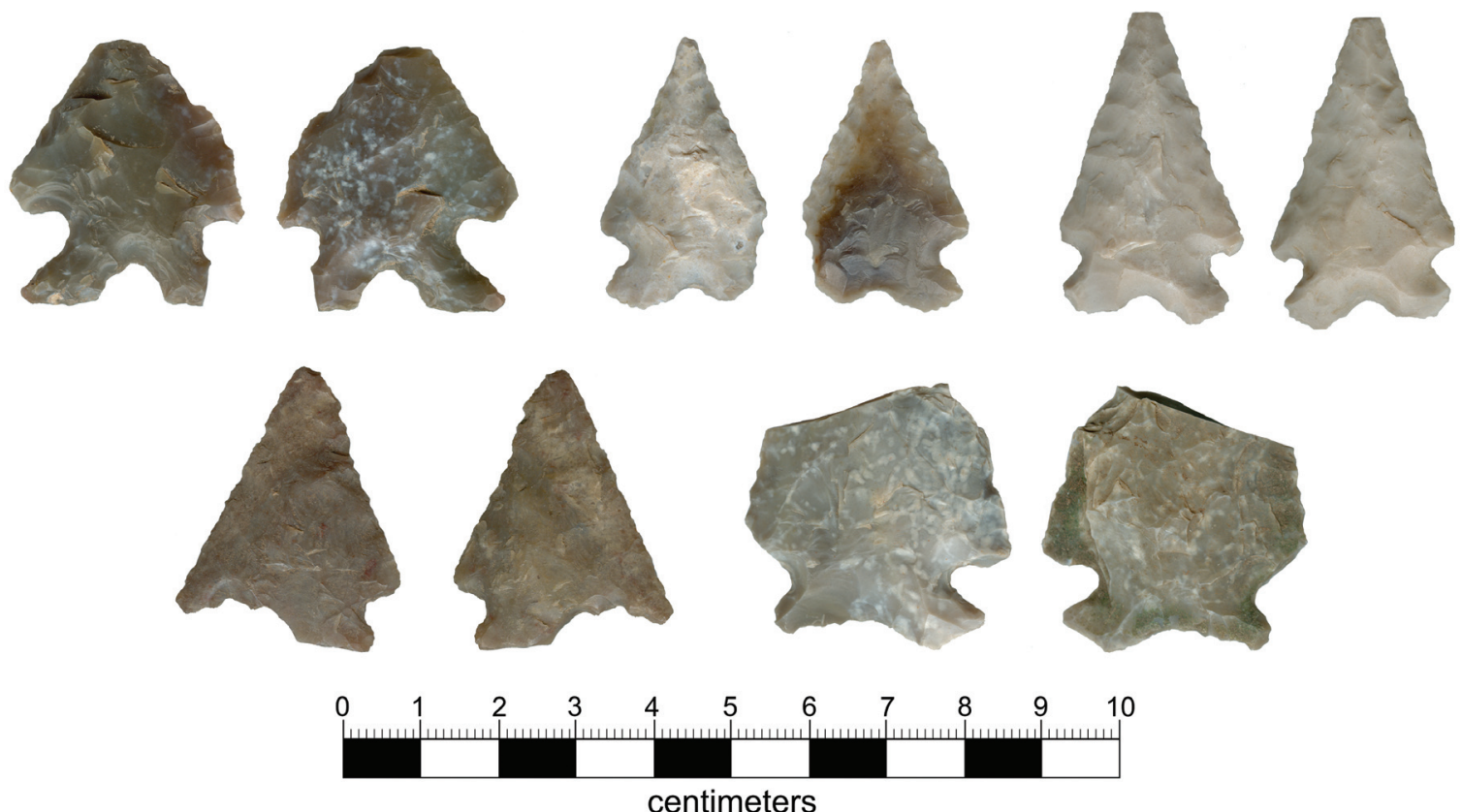

Figure 2-10. Frio points recovered from the Herd Ranch by Chesly Herd.

longer used atlatls (spear throwers) to hurl spears at their prey, but instead had adopted bow-andarrow technology. This involved a substantial reduction in the size of projectile points, as well as an increase in the number of bifaces that were manufactured. Previously, many "projectile points" were also used as hafted knives, or exclusively as knives, and the abandonment of the atlatl meant that a single tool could no longer be used both as a knife and a projectile tip. Another significant technological shift was the incorporation of pottery (Black 1989:32; Story 1985:4547).

\section{Austin}

As noted, the Austin period is distinguished from the preceding period primarily by the appearance of arrow points. Scallorn and Edwards types are the most common across Central Texas, but other types including Alba also occur (Figure 2-12). Evidence for increasing social strife, and perhaps increasing overall populations, is seen in multiple burials from Central Texas that date to this period. Many of these burials reveal
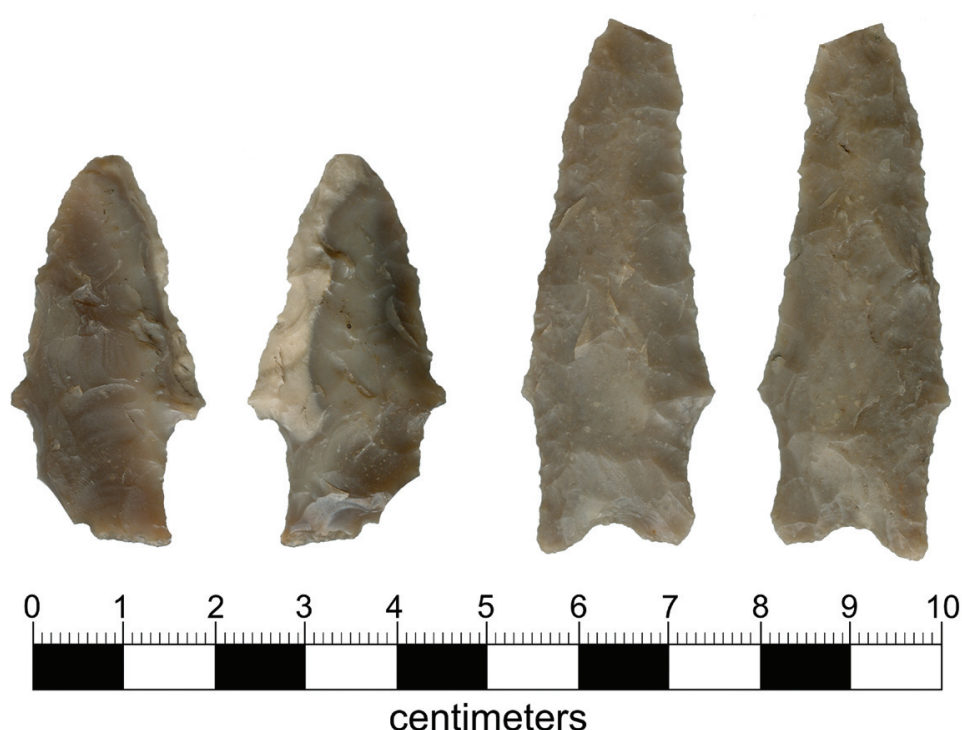

Figure 2-11. Darl points characteristic of the very end of the Late Archaic recovered from the Herd Ranch by Chesly Herd. 

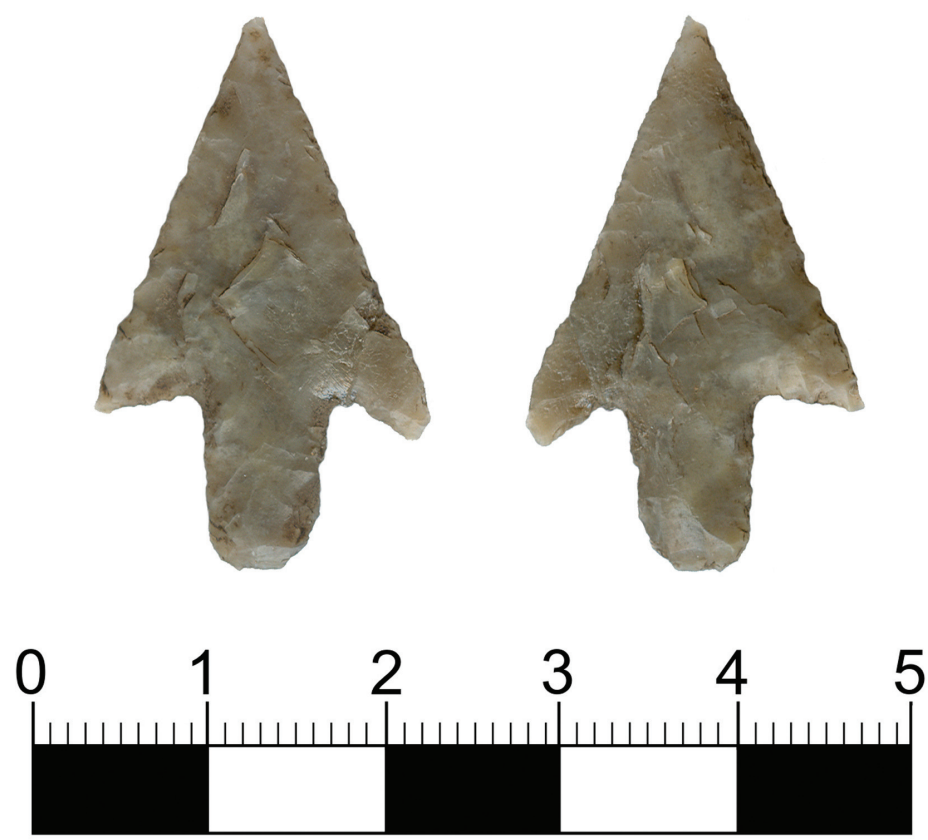

\section{centimeters}

Figure 2-12. A well-made Alba point from the Herd Ranch. The "drooping" shoulder barb is typical of this type, and may have been used to help signify intergroup affiliations.

numerous arrow wounds, some leading even to death, suggesting that population growth resulted in disputes over limited resource availability (Black 1989; Prewitt 1974). Burned rock middens are occasionally found with these types of points (Houk and Lohse 1993), and ground and pecked stone tools, used for plant food processing, become increasingly common in the Austin phase. Analysis of chipped stone tools and related production materials from the Zatopec site in San Marcos indicate strong similarities between Austin-period remains and those from preceding Late Archaic II deposits (Lohse 2010). Based on these similarities, which have also been noted elsewhere (Arnn 2010; Collins 1995; Johnson and Goode 1994), many archaeologists in Central Texas view the transition from the later part of the Late Archaic into the Austin period as one of cultural continuity rather than replacement or abrupt change. This view represents something of a departure from earlier research (e.g., Kelley 1947) that focused on the introduction of bow and arrow technology, beginning with Austin period remains, as indicating a dramatic cultural shift across Central Texas.

\section{Toyah}

The Toyah period is considered by many to be among the most dynamic in Texas prehistory (e.g., Collins 1995:385-386) because it immediately predates, and extends slightly into the period of Spanish exploration. Working with accounts written by explorers, soldiers, and missionaries, archaeologists and ethnohistorians (e.g., Foster 2008; Hickerson 1994; Krieger 2002; Newcombe 1999; Wade 2003) know a great deal more about the cultural identity of indigenous groups who lived in Texas during this period than for any other prehistoric era. This rich record has recently been put to use by archaeologists who, dealing with later-period Late Prehistoric remains, have proposed models addressing the social diversity of Toyah folk and what it meant for the development of the archaeological remains in some regions (e.g., Arnn 2007, 2010; Kenmotsu 1994). In most basic terms, the beginning of the Toyah interval $(750 \mathrm{BP})$ is characterized by contracting stem points with flaring, barbed shoulders, a style known as Perdiz (Figure 2-13); by the common occurrence of blade technology (Black and McGraw 1985; Huebner 1991; Ricklis 1994); and by the appearance of bone-tempered pottery in Central Texas (Johnson 1994:241-281). Together these traits are recognized as part of an effective, wide-spread bison hunting adaptation 

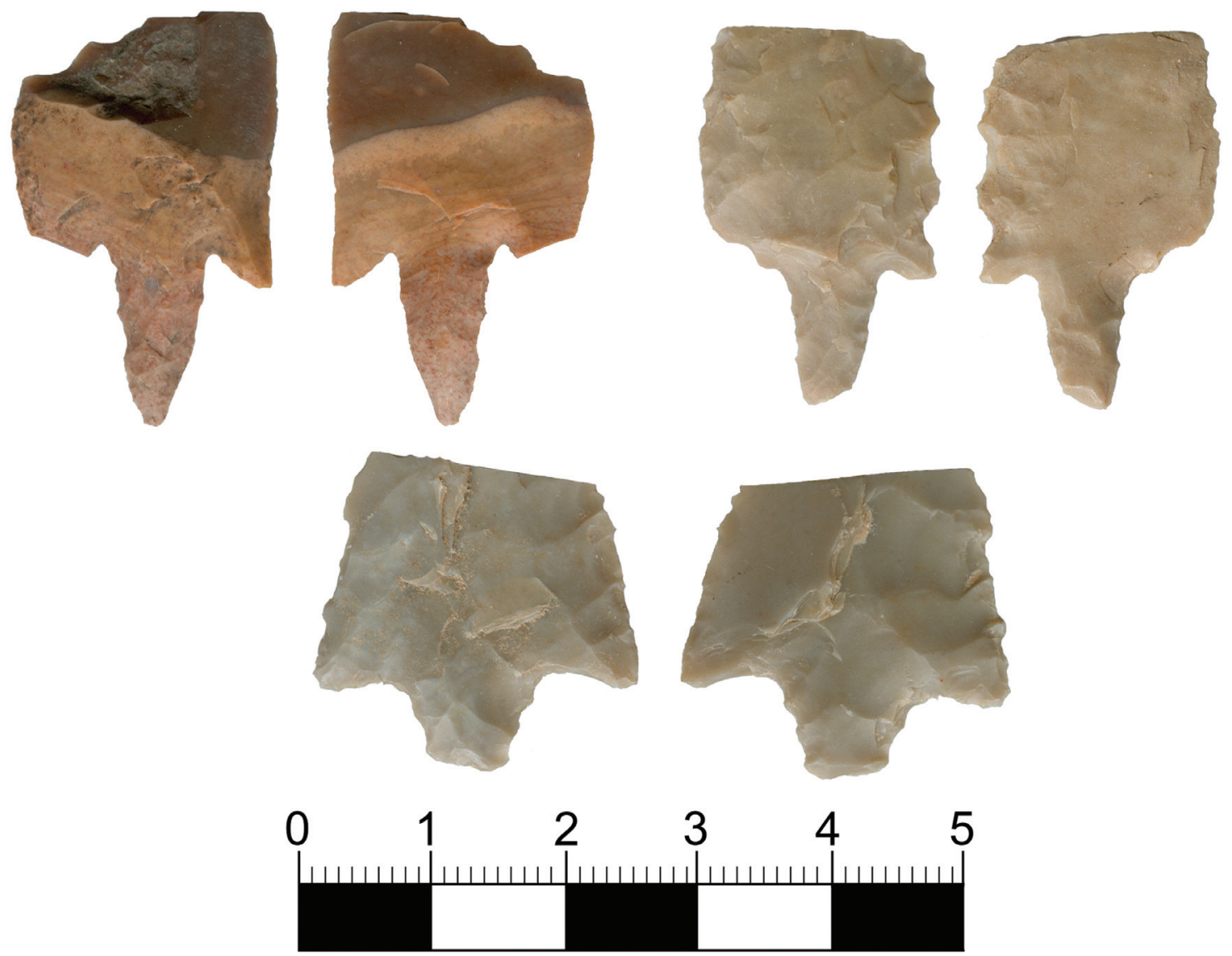

centimeters

Figure 2-13. Perdiz points recovered from the Herd Ranch. All are broken, and specimen at top left has also been fractured by exposure to extreme heat.

that was integrated with east-west trade networks linking Mississippian villages with Pueblos in the American Southwest (Spielmann 1991). As such, Toyah peoples are understood to have focused heavily on that resource for subsistence needs as well as for the benefits of economic exchange.

Common (i.e. traditional) views of Toyah focus on whether the vast spread of material similarities indicate a single ethnic group that covered approximately $80 \%$ of the state of Texas plus neighboring regions to the north, west, and south (Johnson 1994), or whether a single technological adaptation was adopted by diverse cultures who occupied this area (e.g., Black
1986; Ricklis 1994). John Arnn (2007, 2010) has recently attempted to bridge the gap in time between the earliest European accounts of Native Americans in present-day Texas and the latest prehistoric period, describing what he terms a "Toyah social field" comprised of local and long distance interactions by as many as fifty discrete groups who occupied neighboring, and in some cases overlapping territories. Arnn (2010:20) draws from early accounts, including those from the Alonso de Leon Expedition (1689), Álvar Núñez Cabeza de Vaca (1528-36), Bosque-Larios Expedition (1675), Castillo-Martin Expedition (1650), Guadalajara Expedition (1654), MendozaLopez Expedition (1683-84), Joutel (1687), Salas 
(1629), and the Teran Expedition (1691-92), that all describe a network of (mostly) friendly alliances between indigenous inhabitants across most of Texas. Of these, perhaps the most revealing account was written by Fray Francisco Casañas de Jesús María in 1691 (Hatcher 1927). During the late-seventeenth century, Casañas worked among the Hasinai, one of several Caddo groups in the province of Tejias, a Caddoan word that is commonly interpreted as friend or ally. Casañas (Hatcher 1927:2) proceeds to list "the friendly tribes called the Tejias," including 27 allied groups and 17 groups that were frequently hostile to the Hasinai coalition. The Spanish version of Tejias, Tejas, means "friend" and is commonly identified as the root origin of "Texas." In its historical context, the term refers to a large grouping of several culturally and ethnically distinct groups that interacted with each other across a broad geographic range that covered most of what is today Texas (Arnn 2010:20).

From an archaeological perspective, the wide variety of ceramic styles and influences seen throughout Toyah assemblages provides information concerning the social composition of these cultural groups, as Toyah pottery displays Caddo (east), Texas Gulf Coast (southeast), and Jornada Mogollon (west) influences (Arnn 2005). In addition to shifts in material technology, Mauldin et al. (2009) suggest that bison herds foraged across increasingly widespread ranges, at least partly in response to climatic patterns as described above. They (Mauldin et al. 2009) conclude that this change in bison herd behavior is partly responsible for what they identify as a change in Toyah hunting strategy, one that involved increasingly logistically-organized hunting forays in pursuit of spatially dispersed herds. In other words, smaller bands of specialized bison hunters pursued their prey across ever-increasing distances as the herds themselves wandered across larger ranges in search of suitable forage. These long-distance treks would have been another way for cultural traits to become shared widely across a very broad region.

In face of these arguments for a heavy focus on bison, Phil Dering (2008) argues from zooarchaeological and archaebotanical data taken from a number of Toyah components for broad, rather than narrow, diet breadths during Toyah times. While these conclusions appear to be contradictory, taken together they actually pose a more complete and accurate overview of Toyah subsistence behavior. Specialized bison hunters apparently made up an important though limited percentage of economic and subsistence activity within a larger social context of broad-based diet and reliance on a number of available species. In this sense, Toyah seems to more closely resemble Early Paleoindian Clovis adaptations than any other time period. A minor (so far), though significant component of the Toyah pattern apparently included trading for maize, which was used to supplement diets. Although no firm data indicate that maize was grown in Central Texas in Toyah times, maize kernels have been reported from at least three sites: the Kyle Rockshelter (41HI1) in Hill County (Jelks 1962), the Bear Branch site (41CA13) in Callahan County (Adams 2002), and the Timmeron Rockshelter (41HY95) in Hays County (Harris 1985).

\section{Protohistoric (Spanish Entrada Period)}

In Texas, the Protohistoric period, also known as the Spanish Entrada period, was marked by Spanish entradas, the formal expeditions from established forts and missions in Northern Mexico into Central, Coastal, and East Texas in the late-seventeenth and early-eighteenth centuries. These encounters began with the venture into Texas by the Spanish explorer Cabeza de Vaca and the Narvaez expedition in 
1528. The period is generally dated between 1500 and 1700 (or from 1528, the date of the Cabeza de Vaca/Narvaez expedition, to the establishment of the first Spanish mission, Mission San Antonio de Valero in 1718).

With Alonso de León's expedition of 1680, El Camino Real (the King's Road) was established from Villa Santiago de la Monclova in Mexico to East Texas. This roadway followed established Native American trade routes and trails and became a vital link between Mission San Juan Bautista in Northern Mexico and the Spanish settlement of Los Adaes in East Texas (McGraw et al. 1991).

Spanish priests accompanying entradas provided the most complete information of indigenous cultures of early Texas. Those documented during the early entradas include the Cantona, Muruam, Payaya, Sana, and Yojuane, who were settled around the springs at San Marcos and described as semi-nomadic bands. Other tribes included mobile hunting parties from villages in South and West Texas, such as Catequeza, Cayanaaya, Chalome, Cibolo, and Jumano, who commonly moved from their homeland in west Texas to bison-hunting grounds in the Blackland Prairies (Foster 1995:265-289; Johnson and Campbell 1992; Newcomb 1993). Later groups migrated into the region and displaced the former groups or tribes. These included the Tonkawa from Oklahoma and Lipan Apache and Comanche from the Plains (Campbell and Campbell 1985; Dunn 1911; Newcomb 1993, 1999).

Archaeological sites dated to this period often contain a mix of both European imported goods, such as metal objects and glass beads, and traditional Native American artifacts, such as manufactured stone tools. This means that when they are found outside of mission or other strictly European contexts, they can be difficult to recognize.

\section{Historic}

Some researchers demarcate the transition in Texas between the Entrada (Protohistoric) and Historic periods by the construction of the first Spanish missions in Texas. Overall during this time, massive depopulation occurred among the Native Americans, mostly due to European diseases to which the indigenous people had little resistance. Those few indigenous people who remained by the mid-to-late 1800 s were nearly all displaced to reservations (Fisher 1998). Spanish settlement in Central Texas first occurred in San Antonio with the establishment of Mission San Antonio de Valero (the Alamo) in 1718, and the later founding of San Antonio de Béxar (Bolton 1970; Habig 1977; de la Teja 1995).

New Spain's frontier extended for a time as far north as Menard County. As mentioned in Chapter 1, the Mission Cruz de San Sabá was established in 1757 to Christianize the Lipan Apache bison hunters who roamed here. Along with the mission, a presidio was established approximately five miles upstream to garrison soldiers whose task was to protect the mission friars and also to provision the fledgling settlement with essential supplies. The mission and presidio were important elements of the Spanish efforts to expand their colonial empire north into present-day Texas. In addition to proselytizing Christianity, important goals for the Spanish were developing promising deposits of gold and silver that had earlier been identified along the Llano River in present-day Mason and Llano Counties, and settling territory that had been claimed for Spain (Hall 2001). These were sympathetic objectives that had been pursued over and again throughout the Spanish colonial 
New World: subdued local indigenous groups had long been used to provide labor for mines and other economic activities that contributed to the enrichment of local administrators as well as to the Spanish crown back home. However, less than a year after it was established, the Mission Cruz de San Sabá was destroyed by a consortium of Native American groups including Wichita, Comanche, and Caddo warriors (Hall 2001), signaling the beginning of the end of Spanish colonial presence this far to the north of their core area. The presidio, too, was attacked but survived for another 15 years before it was abandoned, in 1772.

Following Texas independence from Mexico in 1836, greater Central Texas was gradually established by Anglo settlers, including many European immigrants like those from Germany, who settled towns like New Braunfels and Fredericksburg, and Sweden, who were important in settling communities to the east of Austin. Trade prospered once Texas was annexed into the Union in 1845 , and people increasingly traveled to the west as important routes were established like the "Upper Road" from San Antonio to El Paso and beyond. These routes, however, remained susceptible not only to hostile Native Americans like the Comanche, who followed the Apache south and were gradually displaced from their hunting grounds, but also from the general lawlessness of the frontier. In response, the U.S. Army established a series of forts along the western edge of the Central Texas Hill Country, one of which was Fort McKavett. Ft. McKavett was occupied by the military from 1853 to 1859 , and again from 1868 to 1883 (Earls and Leffler 1996), with its use interrupted by the Civil War. From here, military strikes were carried out against hostile (and sometimes not so hostile) Native American groups. Given the protection afforded by the outpost, civilian settlement, too, prospered. For example, close to Ft. McKavett was the informal, ramshackle settlement of "Scabtown." This area included a number of saloons, brothels, and gambling places, all representing services that were banned at the fort itself. By around 1880, the threat of Native American hostilities was largely overcome, reducing the military role of Ft. McKavett in the region. In 1882, the fort was ordered abandoned; this was carried out by the following year (Texas Beyond History 2001). In only a few years, the fort was occupied by a civilian settlement occupied largely with raising sheep and goats. 


\section{Chapter 3}

\section{Results of Survey, Testing, and Analysis}

Jon C. Lohse, Julian A. Sitters,

Cinda L. Timperley, and Sarah Scogin

A total of twelve sites, 41MN62 to 41MN73,

Ranch(Figure 3-1). These sites represent primarily were recorded during the CAS survey of the Herd

prehistoric, but also some historic occupation of

FIGURE 3-1 REDACTED

Figure 3-1. Locations of each of the twelve sites recorded on the Herd Ranch during the 2009 CAS survey. 
the area. Each site was recorded on the basis of surface observations during pedestrian survey. These observations were supplemented in many cases with shovel testing to examine for subsurface deposits. Two, 41MN68 and 41MN69, were further examined by limited backhoe trenching. Together, these sites begin to convey something of the remarkable, and virtually pristine, record of prehistoric occupation that defines this region of Central Texas. Each individual site is described below.

\section{MN62: the Z Herd Site}

Named after the Herd family ranch brand, Rafter Z, the Z Herd site is located in the northwestern portion of the ranch on the eastern side of Milligan Draw. This site was initially observed by Dr. Michael B. Collins when he was walking over the ranch in early 2009 with members of the Herd family. Soils covering the site include Knippa silty clay loam (KpA); here, these are thin and much deflated. These sediments derive from the very slow process of in-place bedrock weathering, biodegrading organic matter, and rare flood events from Milligan Draw. As such, soils covering the site are very shallow.

The $\mathrm{Z}$ Herd site appears to contain an unusual alignment of large rocks arranged in a semi-circular formation, suggestive of a large tipi ring (Figure 3-2). During its survey, CAS archaeologists mapped these rocks with a metric tape and compass, plotted their location with a hand held GPS device, and carefully inspected the ground surface for visible artifacts. Although a few of shovel tests that were excavated in the area did not reveal any indication of cultural

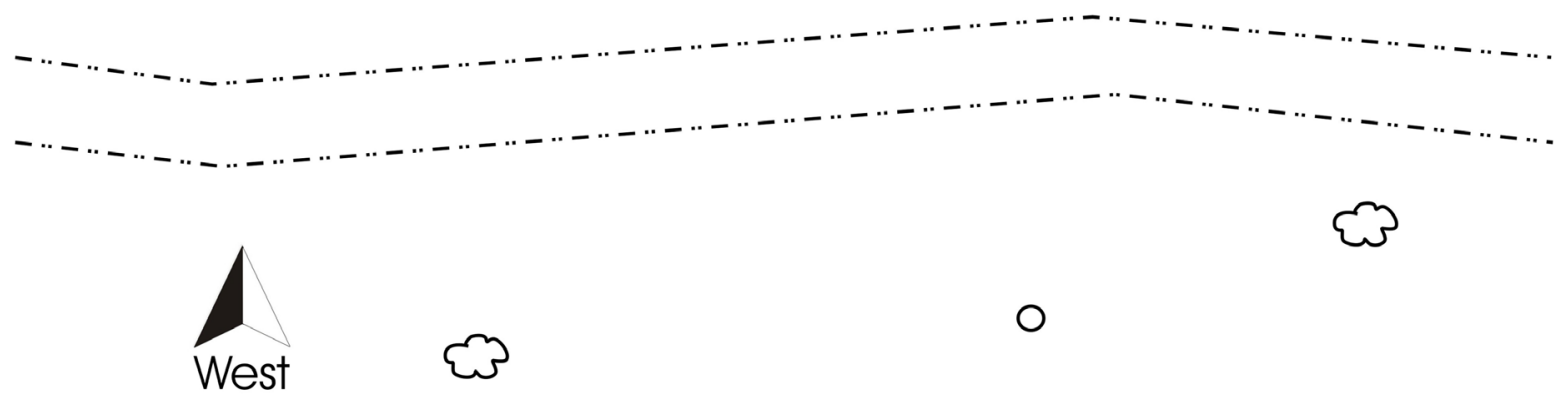

x $\quad 0$

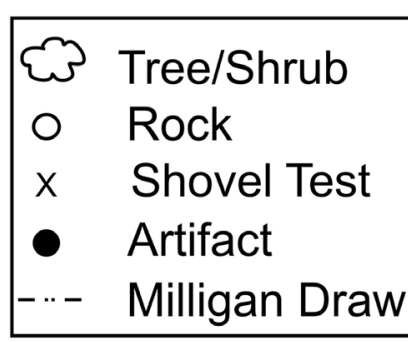

O

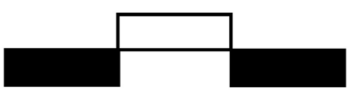

15 meters

Figure 3-2. Map of 41MN62, the Rafter Z Site. 
remains, a chert cobble that had been roughly flaked into a bifacial tool was noted just outside the rock alignment.

The horizontal extent of the site, as delineated partially by the Milligan Draw drainage and partially by CAS 2009 ground surface survey, measures approximately $25 \times 25 \mathrm{~m}$. Vegetation includes low grasses that obscure much of the ground surface (Figure 3-3). Bedrock is present at $\sim 13 \mathrm{~cm}$ below the surface, and the chance that buried cultural remains are present is low. Nevertheless, the possibility that historic-era tipi rings are present in this region is significant, as this period, while richly represented at nearby Ft. McKavett, is poorly known from the Native American perspective. Although the site's research value is presently unknown, it would significantly increase if comparative studies were available for the region, particularly for areas that are relatively close to the fort. 41MN63

\section{$41 \mathrm{MN} 63$}

Site $41 \mathrm{MN} 63$ is located in the far northwestern portion of the ranch, on the western side of Milligan Draw and less than 300 $\mathrm{m}$ from the western property line. This site occupies an upland setting, with very thin, localized soils that barely cover outcropping bedrock. Sediments have been mapped as Valera silty clay loam (VaB); for the most part, these have developed in place as organic matter degrades over slowly weathering bedrock. Wind-born sediments (eolian deposits) have probably also contributed to sediment build-up, albeit minimally. Bedrock is present at the surface across much of the site in the form of large limestone slabs and cobbles (Figure 3-4). Because of the very thin nature of the soils that cover the area, no shovel tests were possible; all cultural materials that are present here are limited to the surface. The horizontal

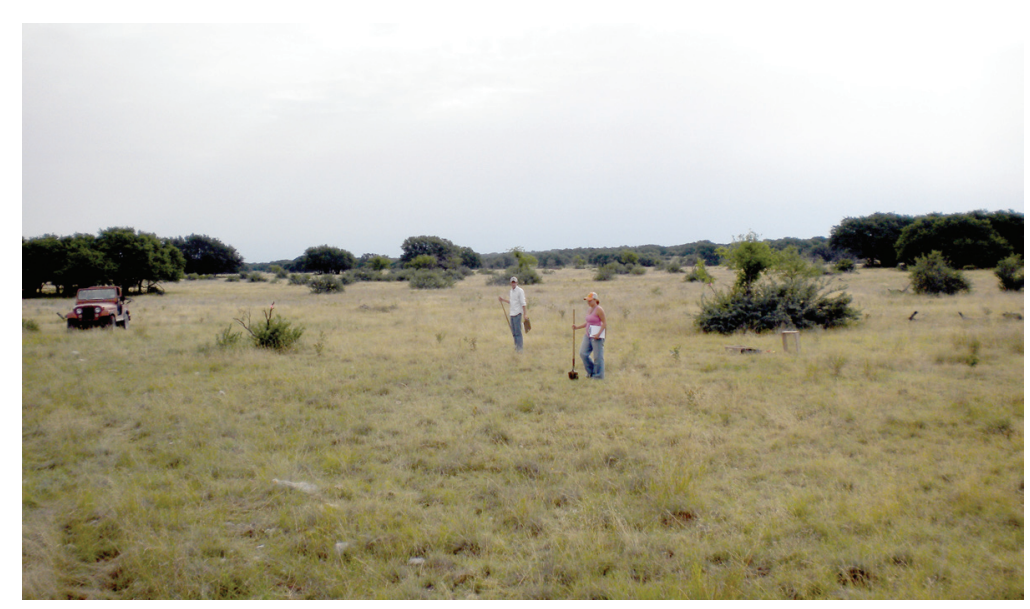

Figure 3-3. Z Herd, 41MN62, site overview looking northeast. CAS archaeologists Sarah Scogin and Julian Sitters are shovel testing an area within the circular stone alignment.

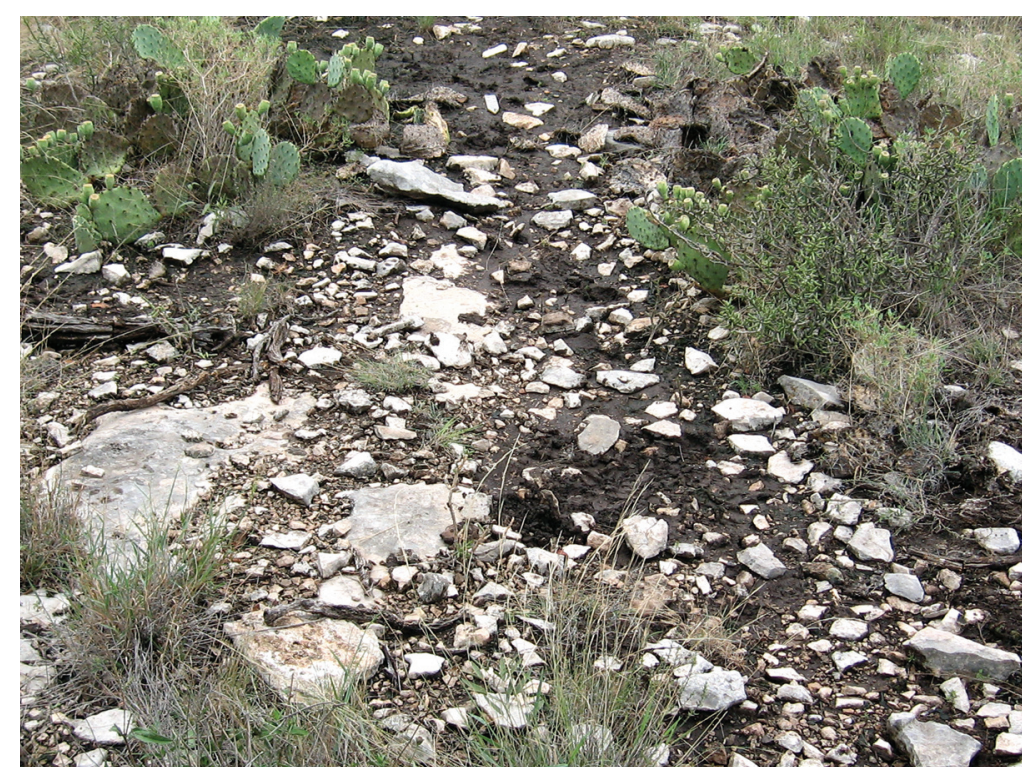

Figure 3-4. Ground exposure at 41MN63 showing bedrock outcropping through thin, upland soils. 
extent of the site, as delineated by ground surface survey, measures approximately $100 \mathrm{~m}(\mathrm{~N} / \mathrm{S}) \mathrm{x}$ $30 \mathrm{~m}(\mathrm{E} / \mathrm{W})$.

The site is an upland lithic scatter, containing a low frequency of artifacts that include broken chert cobbles that exhibited flaking. Tested cobbles that are present were probably deemed unsuitable by Native Americans seeking materials for tool-making. Such cobbles are common on upland lithic scatters, and represent the process of sampling exposed raw materials that might be suitable for tool manufacture. Additionally, two bifaces and a low frequency of flaking debris (debitage) were noted here. Early-stage bifaces were often crafted at or near extraction sites, and so are not uncommon at procurement sites such as this one. One of the bifaces resembles what may be a fragment of a projectile point, although this artifact has clearly been flaked on both faces, and given the artifact's small size no patterning can be discerned among the flake scars (Figure 3-5). Considering that this site represents raw material extraction and early-stage reduction, a viable alternative interpretation for this artifact is that it likely represents a person practicing removing small flakes from bifacial artifacts, and it was never intended to become a projectile point.

These kinds of surface lithic scatters are common in upland regions of Central Texas, and are considered by archaeologists as areas of stone resource exploitation, extraction, and procurement. Although the terrain around this site is deflated in terms of soil build-up, the site is in overall good condition. No evidence was found indicating that the site was occupied on anything other than a temporary, task-specific basis. Rather, the site should be viewed as evidence for special-purpose resource extraction activities that were conducted in the upper San Saba River Valley during the prehistoric past. At present, the research value of the site is unknown, and should be best assessed in conjunction with other sites, and other types of sites, from the region.

\section{MN64}

Site 41MN64 is located on top of a bedrock knoll in the exotic game enclosure in the northwestern portion of the Herd Ranch. Like $41 \mathrm{MN} 63$, this site is an upland lithic scatter that appears to lack distinct or recognizable cultural features. Soils covering this area have been mapped as Tarrant-Kavett Complex clay loam (TK). These are thin to non-existent, and bedrock is present across much of the site surface. Ground cover is sparse in some areas but heavy in others, leaving visibility considerably limited where dense stands of grass or trees occur (Figure 3-6). When CAS archaeologists documented the site, 


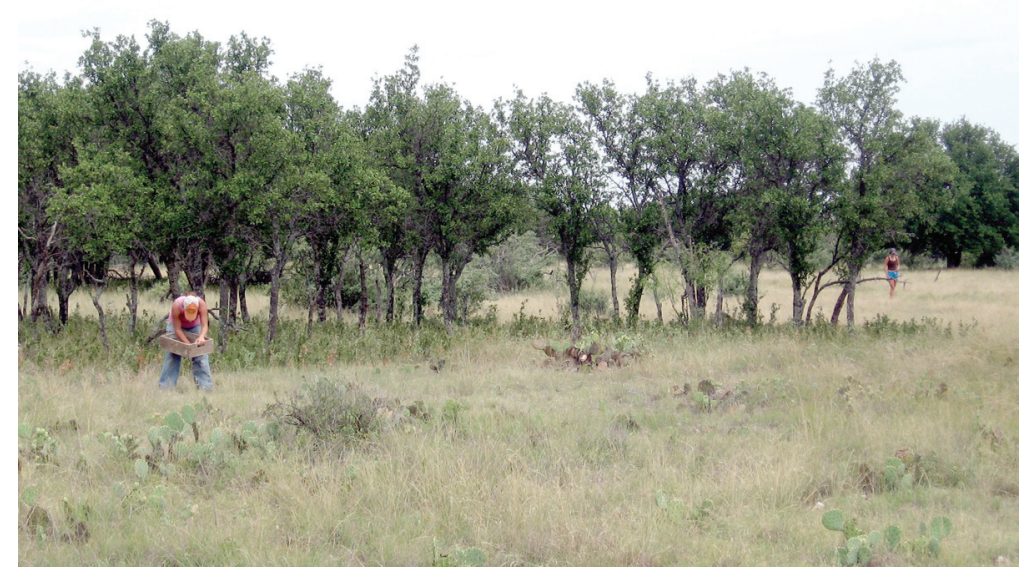

Figure 3-6. Site 41MN64 overview. CAS archaeologist Sarah Scogin (left foreground) screening dirt from a shovel test, and Chesly Herd (right background) examining the surface for artifacts. as an upland lithic scatter, similar in nature to $41 \mathrm{MN} 63$. Prehistoric visitations here appear to have been brief, or at least they did not leave significant amounts of material remains, and were focused on extracting chert material that could be used for tool production. The research value of the site is unknown and should be assessed in conjunction with other site types in the region.

\section{$41 \mathrm{MN} 65$}

Site $41 \mathrm{MN} 65$ is located they conducted a careful inspection of the ground surface and excavated a limited number of shovel tests in areas where sediments were sufficiently deep. As it turned out, this included only a very limited area, and virtually all of the information needed to record the site was visible on the surface (Figure 3-7). The horizontal extent of the site measures approximately 30 $\mathrm{m}(\mathrm{N} / \mathrm{S}) \times 60 \mathrm{~m}(\mathrm{E} / \mathrm{W})$.

The site has a low frequency ofartifacts that donotindicate that the site was occupied on any sort of long-term basis. Site recorders observed a small amount of chipping debris, indicating general flaking of chert nodules, and one unifacially worked piece of chert. This tool was indistinct in character, and provides no real information about the kind or nature of activities that were carried out here. Taken together, the upland nature of the site and its thin, dispersed scatter of lithic remains all characterize the site

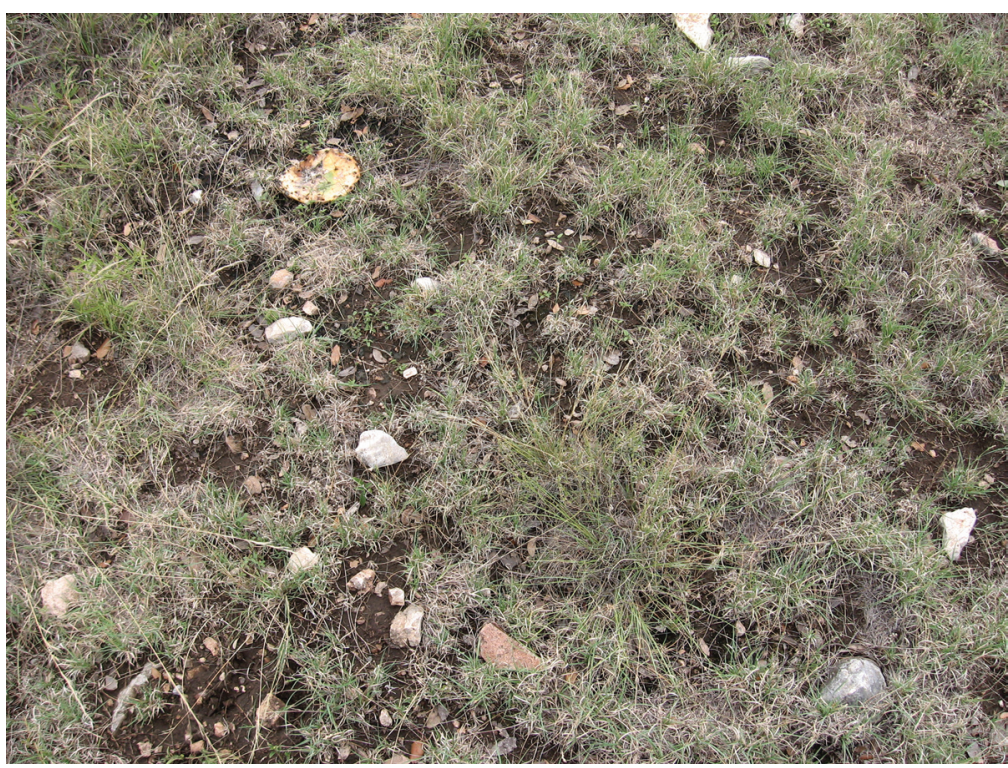

Figure 3-7. Ground surface at 41MN64. The scattered rocks visible in this photograph include a number of natural limestone cobbles, and also a small amount of flaking debris indicating prehistoric activity. 


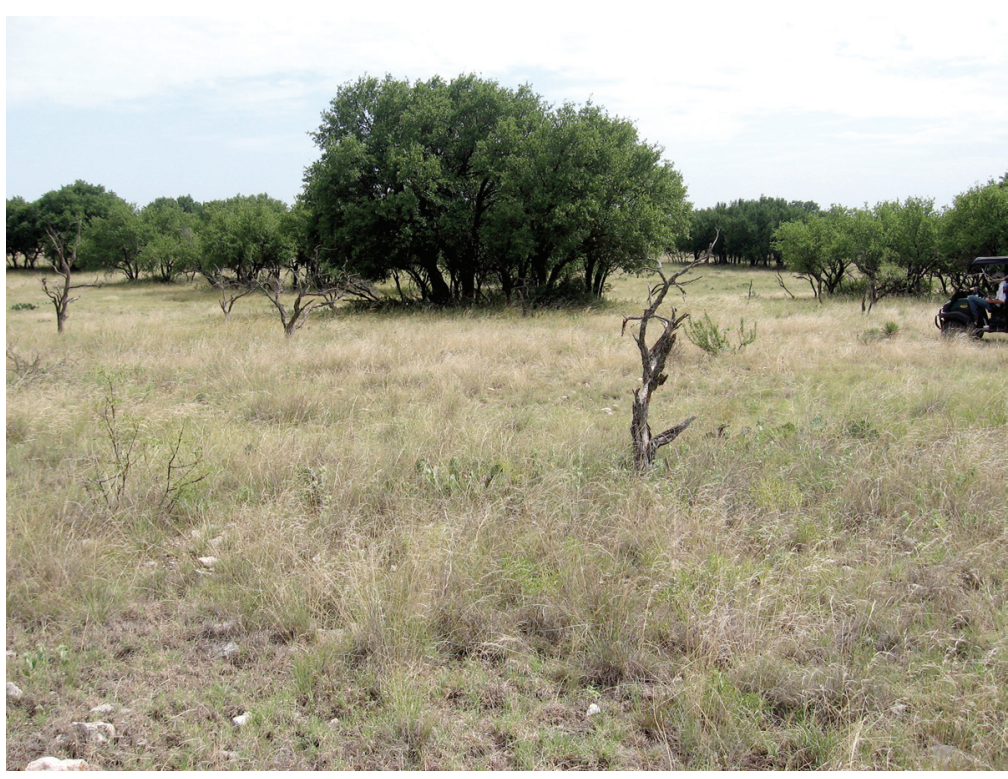

Figure 3-8. Site 41MN65 terrain overview.

across much of the site area (Figure 3-8). When the site was recorded, no shovel tests were excavated, so instead a careful ground inspection was conducted. This work recorded a low frequency of scattered chipping debris and lightly tested chert cobbles. The horizontal extent of the site measures approximately $60 \mathrm{~m}(\mathrm{~N} / \mathrm{S})$ x $50 \mathrm{~m}$ $(\mathrm{E} / \mathrm{W})$. As with the other lithic scatters recorded on the Herd Ranch, site 41MN65 is an area of resource exploitation and procurement. sites, is very thin and altogether absent in some parts of the site with bedrock visible at the surface. The site was recorded when CAS archaeologists noted a surface scatter of chipped stone artifacts across the surface. Because of the thin-to-non existent soils, only one shovel test was excavated; no sub-surface cultural remains were present. Based on the dispersed scatter of artifacts, the horizontal extent of the site measures approximately $200 \mathrm{~m}(\mathrm{~N} / \mathrm{S})$ x $50 \mathrm{~m}(\mathrm{E} / \mathrm{W})$.

The site is classified as an upland lithic scatter with a possible historic component. The site contains a low frequency of artifacts, none of which reflect occupation. Artifacts that were collected from the site include one unifacial tool, two bifacial tools, chert flakes with edge damage, and a metal fragment (Figure 3-10). The metal fragment is a long, slender triangular piece that has possible cut-outs along one edge. This item could not be identified and it likely represents debris from historic ranching or grazing. A shovel test was

\section{$41 \mathrm{MN} 66$}

Site 41MN66 is located to the southwest of the ranch's exotic game enclosure. The site sits largely in an upland setting, but also includes side-slope areas trending downward to the southeast. This area slopes slightly south, and contains short to tall grasses, cacti, and small tree groves (Figure 3-9). Tarrant Soil clay loam $(\mathrm{Ta}$ ) covers the site, and as is the case with previous

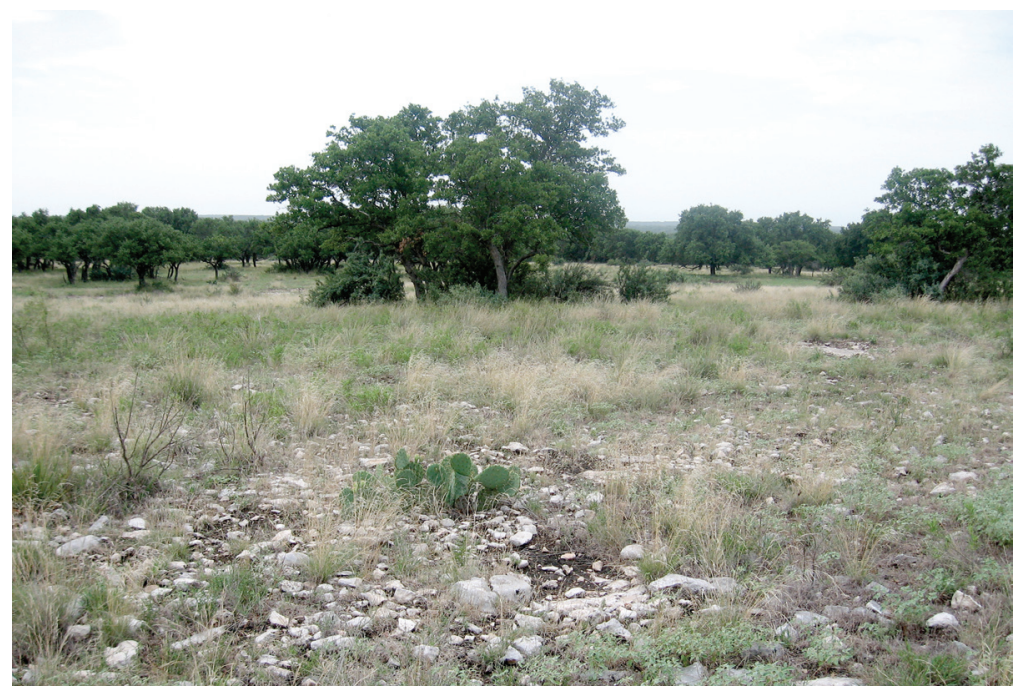

Figure 3-9. Site 41MN66 terrain, looking south. 


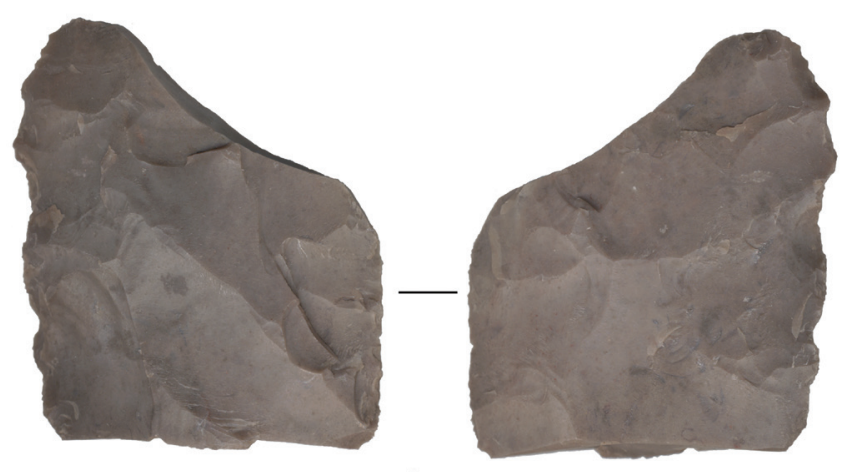

A
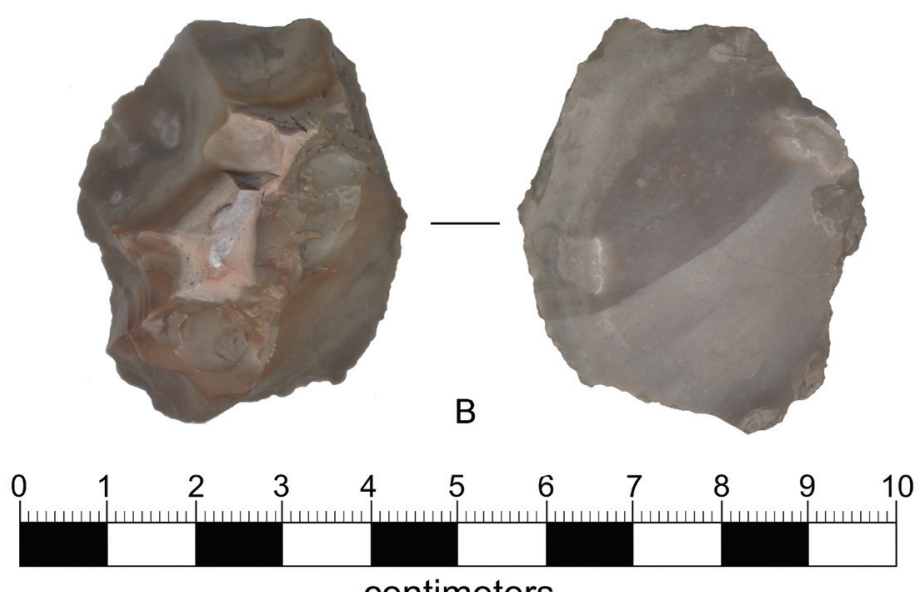

centimeters

Figure 3-10. Chipped stone artifacts recovered from 41MN66, including biface fragment (A) and uniface (B) retaining some cortex.

excavated to investigate subsurface deposits, but was closed at $20 \mathrm{~cm}$ below surface after bedrock was encountered. No artifacts were noted below the surface, and the likelihood that any are present buried across the site is considered low.

Overall, the terrain surrounding the site is deflated, but the site has remained in good condition. In upland portions of the site area, cultural materials are confined to the surface, whereas it is possible that buried remains might be present in lowland areas. This site shows a wider variety of artifact types than is seen at other upland lithic scatters, though not enough that it should be considered as a residential or occupation site. It is more likely that, like other remains from upland portions of the Herd Ranch,
41MN66 represents lithic raw material extraction for toolmaking. The research value of the site is unknown and should be assessed in conjunction with other site types in the region.

\section{MN67}

Site 41MN67 is located only a few hundred meters to the southeast of 41MN66, along a fence line and near an unimproved dirt road. A dry drainage is present to the northwest of the site, and the general terrain is relatively flat with a slight increase in elevation to the northwest. Uvalde silty clay loam $(\mathrm{UaA})$ covers the site; this upland soil is deflated and bedrock is present just below the surface. Because of the thin nature of deposits here, no shovel tests were excavated when the site was recorded. A surface scatter of artifacts extends approximately $190 \mathrm{~m}$ $(\mathrm{N} / \mathrm{S}) \times 45 \mathrm{~m}(\mathrm{E} / \mathrm{W})$, making this site comparable in size to 41MN66 and among the largest lithic scatters recorded during this project.

The site contains a low frequency of artifacts that do not reflect occupation. Artifacts include three bifacial tools, one unifacial tool, chert flakes with edge damage, and several interior chert flakes (Figure 3-11). The bifaces were unfinished, and one appears to have been broken in the process of manufacture. As noted for sites discussed above, this pattern is common at lithic procurement sites throughout Central Texas. Overall, the land surrounding the site has remained in good condition. In order to be fully understood, this 


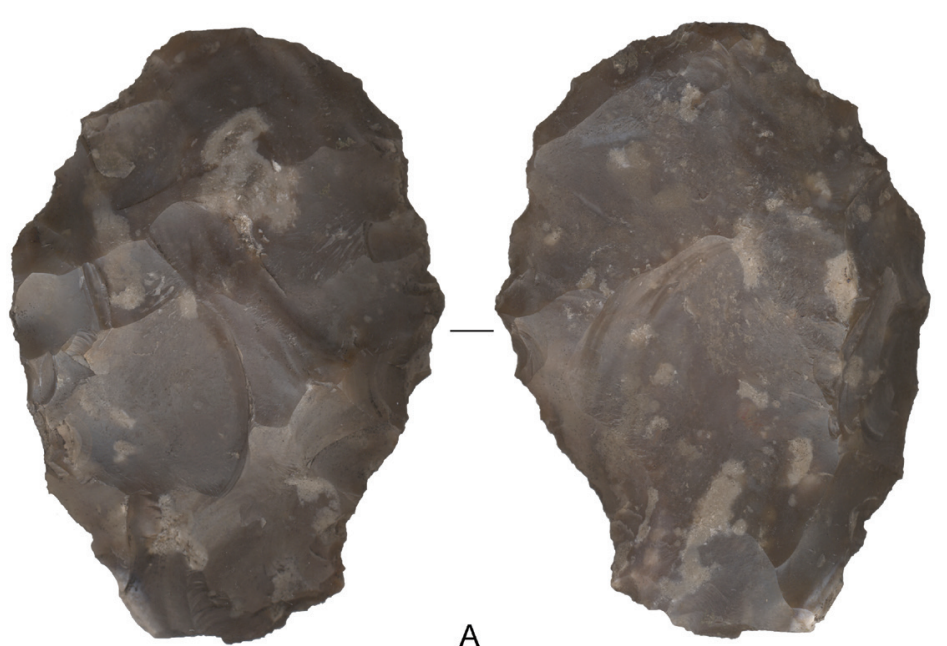

A
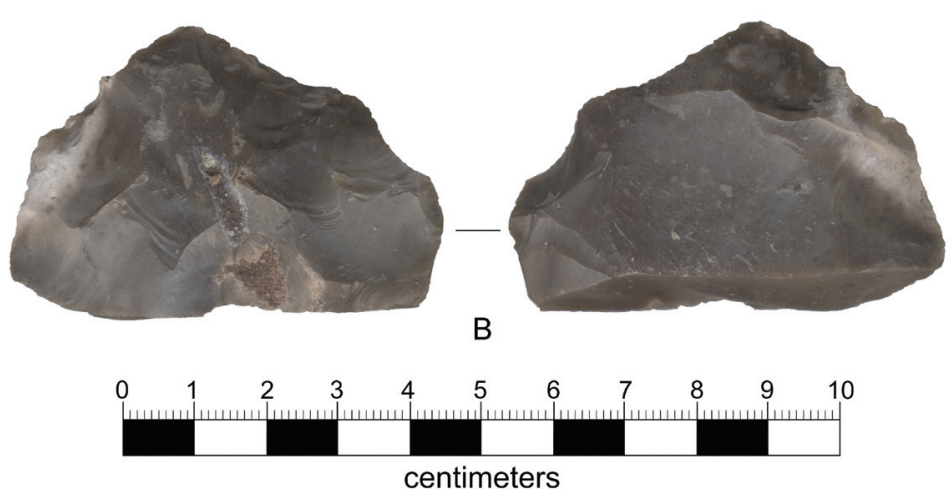

Figure 3-11. Artifacts from 41MN67, including crude biface (A) and biface broken in reduction (B). Both are made from the same chert, which outcrops locally at this site.

site, like procurement sites elsewhere on the Herd Ranch, will need to be assessed in conjunction with a representative sample of site types that reflect the range of prehistoric adaption in the region.

\section{MN68: the D Herd Site}

Named after Herd family member, Dan Herd, the D Herd site is a medium-sized burned rock midden located in deep alluvial soils along the north side of the San Saba River. Soils in this area are mapped as Uvalde silty clay loam (UaB); here, these extend well over two meters in depth before highly weathered, calcium carbonate-rich sub-soils are encountered. The field where the site is located is used intermittently to harvest wheat. An old growth pecan grove is less than 200 meters to the north, and Ranch to Market Road 864 is less than 100 meters to the south (Figure 3-12). The south edge of the site has been lightly impacted by an unpaved ranch road that parallels RM 864 (as well as a historic irrigation canal no longer in use). Aside from this road and the shallow plowing, the site is in excellent condition.

The D Herd site has long been known to the Herd family as a scatter of angular rocks visible on the surface, and a slight elevated rise in this pasture. Dr. Michael B. Collins visited the site in early 2009 , and immediately observed that the rise was likely to be the result of a dense accumulation of burned and fire-cracked rock beneath the surface. When CAS archaeologists recorded the site in July 2009, the site's approximate horizontal extent was evident from surface scatters of cultural materialincluding fire-cracked rock; chert debris, tools, and tool fragments; and occasional faunal remains. The total area is estimated to be approximately $100 \mathrm{~m}$ $(\mathrm{N} / \mathrm{S}) \times 175 \mathrm{~m}(\mathrm{E} / \mathrm{W})$.

The surface extent of cultural materials at the site was mapped using a metric tape and compass, and the site's buried deposits were investigated by five backhoe trenches (Figure 3-13). These trenches were excavated in approximately onefoot levels and dirt from each level was piled separately so that it could be examined later. Ten 
A

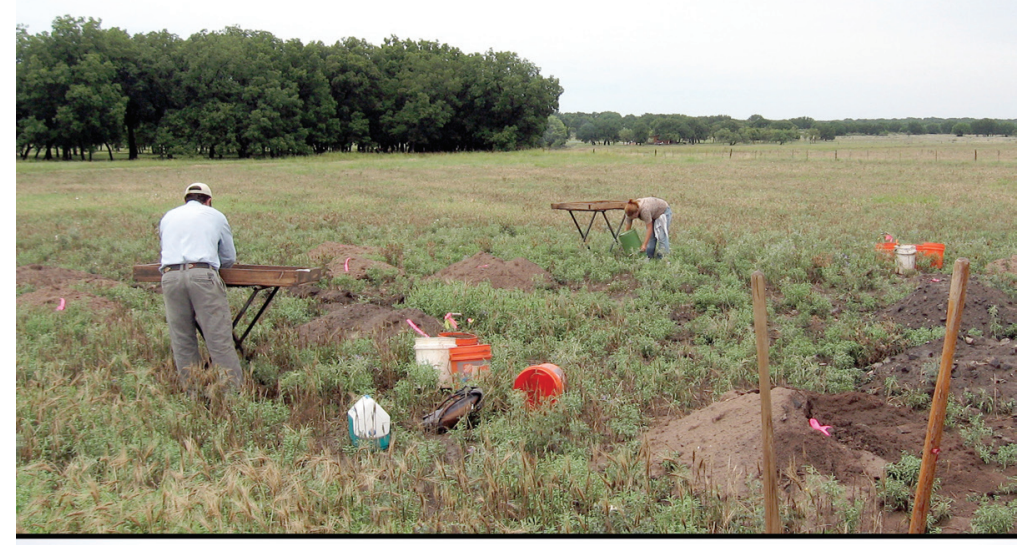

B

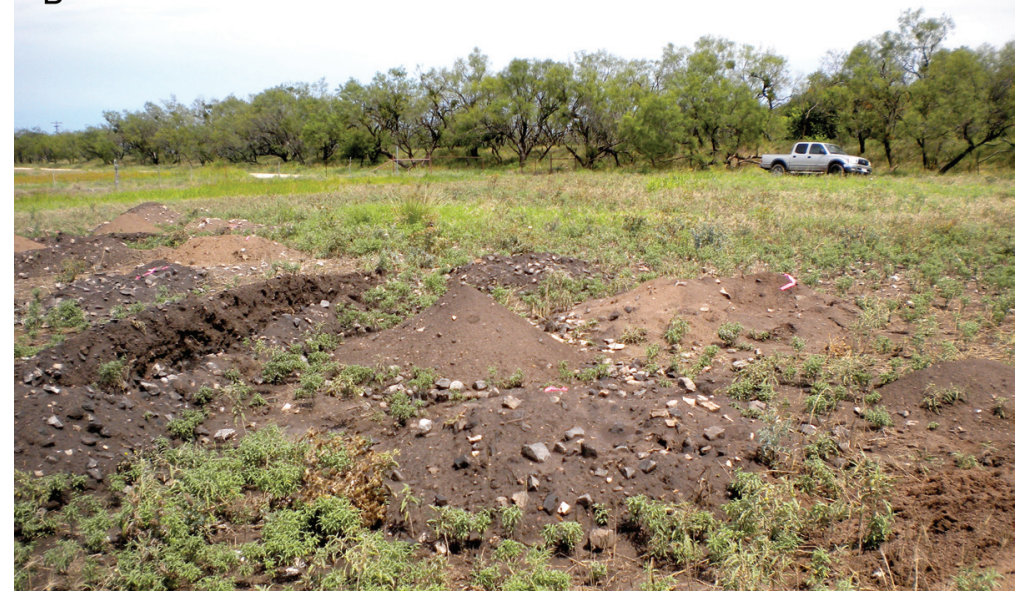

Figure 3-12. Overviews of the D Herd site, 41MN68, looking northeast (A), with pecan grove visible at upper left, and southeast (B), with elevated historic irrigation canal visible behind field vehicle. Angular fire-cracked rock and dark midden soils are clearly visible in the lower photo.

five-gallon buckets of soil were taken from each level of each trench and were screened through 1/4 in hardware cloth to recover artifacts, including faunal remains. Worked pieces of chert and a general, arbitrary sample of flakes were recovered during the screening in order to provide a rough indication of the kinds of artifacts that were present. Additionally, well-preserved faunal remains were recovered as evidence for the kinds of resources that were processed at this site. Finally, profiles of each trench (except for Trench 5 , which filled with rain water immediately after it was excavated and never dried during the duration of this project) were drawn, and samples were taken from trench walls that were submitted for chronometric dating. Results of investigations at $\mathrm{D}$ Herd demonstrate that this locale was an intensive subsistence resource processing area for an extended period of time. Activity occurred here intermittently for a little over 800 years, from perhaps around AD 450-1300. Evidence suggests that these activities were focused heavily, though not exclusively, on processing mussels extracted from the nearby San Saba River. Additional food resources include mammalian taxa such as bison, deer (and perhaps antelope), rabbits, and other regionally available animals. Below, various classes of data recovered from D Herd are presented.

\section{Faunal Remains}

Remains of both terrestrial and aquatic animals were recovered from trenches at D Herd (Table 3-1). Among the notable terrestrial fauna is bison, though only a single tooth fragment was recovered suggesting that bison hunting was not a significant activity in the context of this site. Other terrestrial fauna include white tail deer, cottontail rabbit, and an unidentified canid, perhaps a coyote, dog, or wolf.

In general, the range of taxa included in this sample reflects heavy exploitation of locally available resources, especially those found in the 
FIGURE 3-13. REDACTED

Figure 3-13. Site map of D Herd, 41MN68.

nearby San Saba River. Mollusks and gastropods, in particular, were recovered from nearly all screened levels from the trenches. It is possible that terrestrial fauna are under-represented as a result of poor preservation. Pieces recovered commonly showed weathered, eroded surfaces and heavy leaching of organic content. Nevertheless, the frequency of invertebrate remains, along with the limited range of habitats where these taxa occur (Table 3-2), suggests that the primary focus of this site was the processing of riverine and other locally available subsistence resources.

\section{Site Stratigraphy and Chronology}

Four of the backhoe trenches excavated at the site were profiled (Figure 3-14). Stratigraphy was consistent from trench to trench, and indicates that the site has three main strata.
Stratum 1 is the plow zone that extends across the entire site and down to a consistent depth of approximately $20 \mathrm{~cm}$. This layer contains abundant fire-cracked rock and lithic debris. When the trenches were documented and sampled, archaeologists were careful not to include any of the materials from this stratum for dating, since its contents are highly disturbed from repeated plowing. Stratum 2 is the main portion of the intact deposits, and is defined by dense accumulations of burned and fire-cracked rock. The recorded bottom elevation of Stratum 2 varies from as little as $40 \mathrm{~cm}$ close to the edge of the site to as much as approximately $90 \mathrm{~cm}$ towards the center of the deposit. This layer is consistently characterized by dark, organicrich sediments with heavy ash content resulting from repeated fires for processing food resources, as discussed above. Stratum 2 has abundant chert artifacts, as well as dense pockets of mussel shell and some poorly preserved fauna. The bottom boundary of this stratum is wavy and very indistinct in places. Stratum 3 contains very few fire-cracked rocks; most of the rocks that are present are thought to have been deposited from the above Stratum 2, though some may indeed represent cooking fires at this depth. Some chipped stone debris was also present here, indicating that the site was utilized before the period of intensive midden accumulation. A portion of Trench 2 was extended as deep as the backhoe could safely reach, over three meters, in order to determine the overall depth of the alluvial terrace in this location. At the very bottom of this exposure, heavy deposits of calcium carbonate were encountered. The age 
Table 3-1. Inventory of Faunal Material Recovered from 41MN68, D Herd Site.

\begin{tabular}{|c|c|c|}
\hline $\begin{array}{l}\text { Trench, } \\
\text { Level }\end{array}$ & Invertebrates (mollusks) & Vertebrates (terrestrial) \\
\hline Trench 1, Lv. 1 & $\begin{array}{l}1 \text { right valve, Unionidae, smooth shell. } \\
2 \text { edge fragments, cf. Lampsilis sp. } \\
1 \text { edge fragment, cf. Amblema sp. } \\
1 \text { nacre fragment, Unionidae, smooth shell } \\
1 \text { right valve umbo, Amblema plicata }\end{array}$ & $\begin{array}{l}\text { 1 Odocoileus virginianus upper premolar, } \\
\text { right } \\
1 \text { Leporidae:Sylvilagus upper cheek tooth } \\
1 \text { indeterminate taxon (ca deer size), diaphysis } \\
\text { fragment with fresh break one end, old } \\
\text { step/impact break other end; diagenetic } \\
\text { surface pitting. } \\
1 \text { indeterminate taxon (ca. rabbit-size) } \\
\text { diaphysis fragment, burned, spiral breaks. }\end{array}$ \\
\hline Trench 1, Lv. 2 & $\begin{array}{l}1 \text { left valve fragment with lateral teeth, Family } \\
\text { Unionidae }\end{array}$ & $\begin{array}{l}1 \text { taxon indeterminate, deer-size diaphysis } \\
\text { fragment, possibly burned, spiral breaks } \\
1 \text { taxon indeterminate, rabbit-size diaphysis } \\
\text { fragment, burned, spiral breaks } \\
1 \text { Bison/Bos size enamel fragment, } 2 \mathrm{~cm} \text { long }\end{array}$ \\
\hline Trench 1, Lv. 3 & $\begin{array}{l}1 \text { nearly complete right valve, small, } \\
\text { Unionidae } \\
8 \text { right valve umbos cf Amblema plicata } \\
2 \text { left valve umbo cf Amblema plicata } \\
1 \text { umbo fragment, indeterminate taxon } \\
2 \text { nacre fragments, indeterminate taxon }\end{array}$ & $\begin{array}{l}1 \text { taxon indeterminate (Canidae?), caniniform } \\
\text { tooth root } \\
1 \text { taxon indeterminate (deer-size), rib } \\
\text { fragment? Radius fragment? Fresh break one } \\
\text { end, scalloped other end overprinted on spiral- } \\
\text { break? }\end{array}$ \\
\hline Trench 1, Lv. 4 & $\begin{array}{l}4 \text { right valve umbos cf. Amblema plicata } \\
1 \text { left valve umbo Unionidae ?Lampsilis } \\
4 \text { nacre fragments, taxa indeterminate. } \\
1 \text { nacre fragment, cf. Amblema sp. }\end{array}$ & \\
\hline Trench 2, Lv. 1 & 2 left valve umbos, Amblema plicata & \\
\hline Trench 2, Lv. 2 & $\begin{array}{l}1 \text { left valve, Amblema plicata } \\
1 \text { right valve cf. Amblema plicata } \\
1 \text { left valve umbo, cf } A \text {. plicata } \\
2 \text { right valve umbos, cf } A \text {. plicata }\end{array}$ & \\
\hline Trench 2, Lv. 3 & $\begin{array}{l}4 \text { left valve umbos, Amblema plicata } \\
2 \text { right valve umbos, Amblema plicata } \\
2 \text { right valve umbo, Unionidae }\end{array}$ & \\
\hline Trench 2, Lv. 4 & 1 umbo fragment, taxon indeterminate. & \\
\hline Trench 3, Lv. 1 & $\begin{array}{l}1 \text { left valve umbo, Amblema plicata } \\
1 \text { left valve umbo, Unionidae:? Lampsilis }\end{array}$ & $\begin{array}{l}\text { 1 Artiodactyl first phalanx, deer or antelope? } \\
\text { No apparent modification. }\end{array}$ \\
\hline Trench 3, Lv. 2 & $\begin{array}{l}1 \text { right valve, cf. Amblema plicata } \\
1 \text { nacre fragment delaminated from above } \\
\text { valve, Amblema plicata } \\
1 \text { Rabdotus } \text { cf. Rabdotus dealbatus } \\
1 \text { gastropod, not identified, probably not } \\
\text { terrestrial }\end{array}$ & \\
\hline Trench 3, Lv. 3 & 1 left valve umbo, Amblema plicata & \\
\hline Trench 3, Lv. 4 & $\begin{array}{l}1 \text { left valve umbo, Amblema plicata? } \\
1 \text { mussel shell margin, taxon indeterminate. }\end{array}$ & \\
\hline Trench 4, Lv. 1 & 2 left valve umbos, cf. Amblema. plicata & \\
\hline Trench 4, Lv. 2 & $\begin{array}{l}3 \text { left valve umbos Amblema plicata } \\
2 \text { right valve umbos Amblema plicata } \\
2 \text { left valve umbos, Unionidae:Lampsilis? } \\
\text { 2, umbos indeterminate side, Unionidae? }\end{array}$ & $\begin{array}{l}1 \text { taxon indeterminate, deer-size, diaphysis } \\
\text { fragment, spiral breaks, burned and cut. }\end{array}$ \\
\hline Trench 4, Lv. 3 & 2 shell fragments Amblema plicata & \\
\hline Trench 5, Lv. 1 & $\begin{array}{l}2 \text { mussel shell margin fragments, taxon } \\
\text { indeterminate. }\end{array}$ & \\
\hline Trench 5, Lv. 2 & 1 left valve umbo, Amblema. plicata & \\
\hline Trench 5, Lv. 3 & & \\
\hline Trench 5, Lv. 4 & 1 right valve umbo, Amblema plicata & \\
\hline
\end{tabular}


Table 3-2. Habitats in which fauna from D Herd are commonly found.

\begin{tabular}{|c|c|}
\hline Taxon (familiar name) & Habitat \\
\hline Amblema plicata (three ridge mussel) & $\begin{array}{l}\text { Silt and mud to gravel and cobble substrates, not deep } \\
\text { shifting sands; numerous in firm mud and mud plus } \\
\text { fine gravel substrates }{ }^{1} \text {. }\end{array}$ \\
\hline $\begin{array}{l}\text { Unionidae: cf. Lampsilis (fat } \\
\text { muckets, pocketbooks, sandshells) }\end{array}$ & $\begin{array}{l}\text { Slow to fast-moving water; mud, sand, gravel, rock } \\
\text { substrates } 1\end{array}$ \\
\hline Unionidae & $\begin{array}{l}\text { Slow to fast-moving water; mud, sand, gravel, rock } \\
\text { substrates } 1\end{array}$ \\
\hline Unionidae:Lampsilis? or Quadrula? & $\begin{array}{l}\text { Slow to fast-moving water; mud, sand, gravel, rock } \\
\text { substrates } 1\end{array}$ \\
\hline Unionidae:? Lampsilis sp. & $\begin{array}{l}\text { Slow to fast-moving water; mud, sand, gravel, rock } \\
\text { substrates } 1\end{array}$ \\
\hline Gastropoda & $\begin{array}{l}\text { Slow to fast-moving water; mud, sand, gravel, rock } \\
\text { substrates } 1\end{array}$ \\
\hline Unionidae:Lampsilis? & $\begin{array}{l}\text { Slow to fast-moving water; mud, sand, gravel, rock } \\
\text { substrates } 1\end{array}$ \\
\hline Rabdotus sp.cf. Rabdotus dealbatus & $\begin{array}{l}\text { Sparsely wooded areas, flood plains and grasslands }{ }^{2} \\
\text { Prefers moderate temperature ranges; limited by } \\
\text { calcium levels in soil; can tolerate dry conditions }\end{array}$ \\
\hline Sylvilagus sp. (cottontail rabbit) & Varies by species \\
\hline Canidae? & Varies by species \\
\hline $\begin{array}{l}\text { Odocoileus virginianus (white-tail } \\
\text { deer) }\end{array}$ & Brushy/woody country throughout Texas ${ }^{3}$ \\
\hline Bison or Bos & $\begin{array}{l}\text { Grazer; open prairie } \\
\text { Maximum distribution, late prehistoric times, nearly } \\
\text { continent-wide: mountains, open forests, plains of } \\
\text { North America including northern Mexico and along } \\
\text { eastern slope of Rockies north to Alaska; excluding } \\
\text { eastern two-thirds of Canada (coincident with glaciated } \\
\text { areas) }{ }^{4} \\
\text { Limited now to parks, wildlife refuges, ranches }\end{array}$ \\
\hline Artiodactyla (deer or antelope) & Brushy/woody country throughout Texas ${ }^{3}$ \\
\hline
\end{tabular}

1. Howells et al. 1996

2. Brown 2006

3. Davis and Schmidley 1997

4. Meagher 1986

of this lowermost stratum is unknown, but it probably predates human occupation of the San Saba Valley.

Six sediment samples were selected from various locations of the sidewalls of Trenches 1 and 3. Samples were taken from areas that showed no indication of intrusion or disturbance from rodent burrows or root growth. These were collected in paired fashion in order to date the cultural deposit, including the midden and underlying Stratum 3, and also to verify that the site is intact and well-ordered and has not been significantly disturbed other than by plowing of the upper $\sim 20$ $\mathrm{cm}$ (Table 3-3; calibrated results are also shown on trench profiles). These dates indicate that the unplowed portion of the site is intact; in no cases were paired dates were inverted or out of their expected stratigraphic sequence. The dates also show that the midden dates from ca. AD 420-610 
D Herd, 41MN68, Burned Rock Midden

Trenches 1, 2

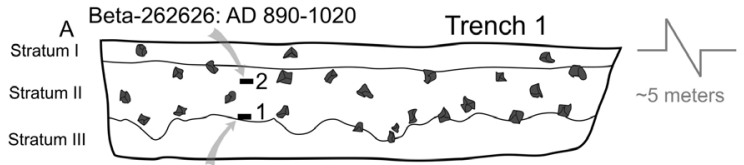

Beta-262625: AD 600-680

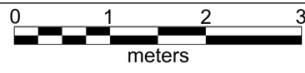

-1 Sample taken for radiocarbon dating - Fire-cracked rock trenches oriented at $30^{\circ} / 210^{\circ}$; northwest wall profiles indicated

Stratum I: topsoil, root and plow zone; rootlets, some fire-cracked rock and chert dislodged from plowing; dark gray-brown (Munsell color 7.5YR 2.5/2) silty clay loam; represents top of burned rock midden, disturbed by plowing

Stratum II: midden deposit; thick fire-cracked rock content, abundant chert debris, few tools; moderate mussel shell, very light fauna; bottom boundary is very wavy, indicating that "pits" may have been dug into underlying sediments and lined with rocks; also some krotovina (root casts and animal burrows); dark brown (Munsell color 10YR 3/2) moderately compact ashy silty loam

Stratum III: underlying B horizon; very few fire-cracked rock and some cher artifacts near the uneven top boundary; few inclusions include occasional alluvial gravel and calcium carbonate concretions that increase downward dark yellowish brown (Munsell color 10YR 4/4) moderately compact clay loam

Stratum IV: not sampled due to extreme depth ( $>2.5$ meters); very dense calcium carbonate content

\section{Herd, 41MN68, Burned Rock Midden} Trenches 3, 4

$A^{1}$
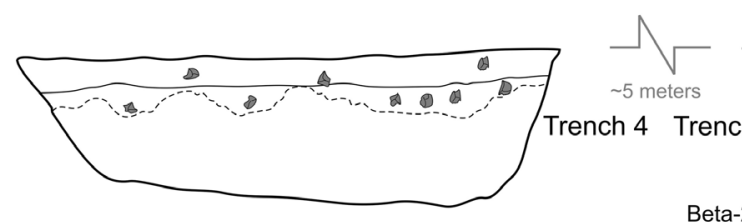

Beta-262628: AD 1230-1300 Beta-262630: AD 990-1160

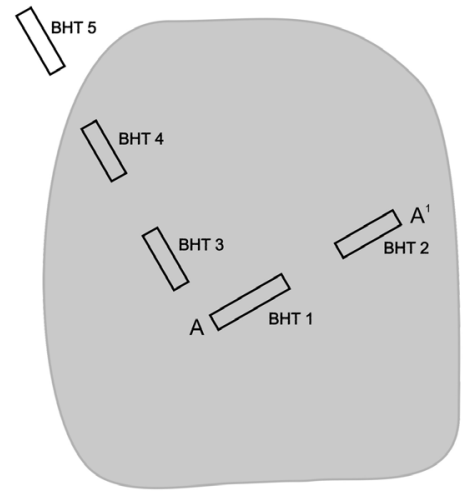

Trench 2 $A^{1}$ Stratum

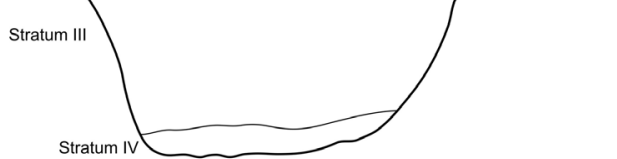

\begin{tabular}{|l|l|l|}
-1 Sample taken for radiocarbon dating & Fire-cracked rock \\
trenches oriented at $120^{\circ} / 300^{\circ} ;$ northeast wall profiles indicated
\end{tabular}

Stratum I: topsoil, root and plow zone; rootlets, some fire-cracked rock and chert dislodged from plowing; dark gray-brown (Munsell color 7.5YR 2.5/2) silty clay loam; represents top of burned rock midden, disturbed by plowing

Stratum II: midden deposit; thick fire-cracked rock content, abundant chert debris, few tools; moderate mussel shell, very light fauna; bottom boundary is very wavy, indicating that "pits" may have been dug into underlying sediments and lined with rocks; also some krotovina (root casts and animal burrows); dark brown (Munsell color 10YR 3/2) moderately compact ashy silty loam

Stratum III: underlying B horizon; very few fire-cracked rock and some chert artifacts near the uneven top boundary; few inclusions include occasional alluvial gravel and calcium carbonate concretions that increase downward; dark yellowish brown (Munsell color 10YR 4/4) moderately compact clay loam

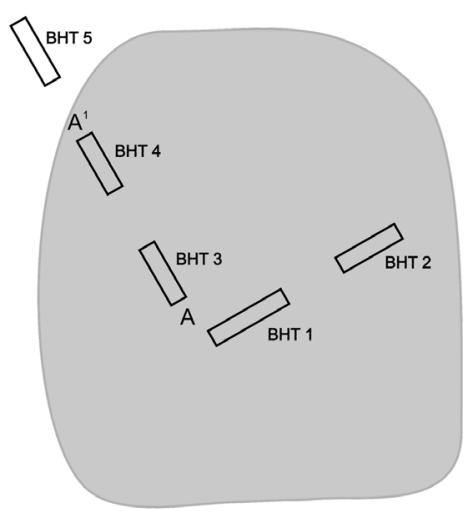

Figure 3-14. Backhoe trench profiles from D Herd. 
Table 3-3. Radiocarbon dates from D Herd.

\begin{tabular}{|l|l|c|c|c|}
\hline $\begin{array}{l}\text { Sample, material } \\
\text { sampled }\end{array}$ & \multicolumn{1}{|c|}{ Location } & $\begin{array}{c}\text { Conventional } \\
\text { Age B.P. }\end{array}$ & $\begin{array}{c}\text { Calibrated, 2 } \\
\text { Sigma age }\end{array}$ & $\begin{array}{c}\text { 13C/12C } \\
\text { Ratio }\end{array}$ \\
\hline $\begin{array}{l}\text { Beta-262625, } \\
\text { carbon }\end{array}$ & $\begin{array}{l}\text { Trench 1, 80-82 cm, } \\
\text { lower boundary of } \\
\text { midden }\end{array}$ & $1390+/-40 \mathrm{BP}$ & AD 600-680 & $-24.7 \mathrm{o} / \mathrm{oo}$ \\
\hline $\begin{array}{l}\text { Beta-262626, } \\
\text { carbon }\end{array}$ & $\begin{array}{l}\text { Trench 1, 40-42 cm, } \\
\text { below top of Stratum } \\
2\end{array}$ & $1080+/-40 \mathrm{BP}$ & AD 890-1020 & $-25.9 \mathrm{o} / \mathrm{oo}$ \\
\hline $\begin{array}{l}\text { Beta-262627, } \\
\text { organic sediment }\end{array}$ & $\begin{array}{l}\text { Trench 3, 53-55 cm, } \\
\text { bottom of Stratum } \\
\text { 2/top of Stratum 3 }\end{array}$ & $1530+/-40 \mathrm{BP}$ & AD 420-610 & $-22.6 \mathrm{o} / \mathrm{oo}$ \\
\hline $\begin{array}{l}\text { Beta-262628, } \\
\text { carbon }\end{array}$ & $\begin{array}{l}\text { Trench 3, 33-35 cm, } \\
\text { immediately below } \\
\text { fire-cracked rock } \\
\text { lens }\end{array}$ & $730+/-40 \mathrm{BP}$ & AD 1230-1300 & $-24.6 \mathrm{o} / \mathrm{oo}$ \\
\hline $\begin{array}{l}\text { Beta-262629, } \\
\text { organic sediment }\end{array}$ & $\begin{array}{l}\text { Trench 3, 70-73 cm, } \\
\text { top of Stratum 3 }\end{array}$ & $2650+/-40 \mathrm{BP}$ & $\begin{array}{c}890-870 \mathrm{AND} \\
850-780 \mathrm{BC}\end{array}$ & $-21.0 \mathrm{o} / \mathrm{oo}$ \\
\hline $\begin{array}{l}\text { Beta-262630, } \\
\text { carbon }\end{array}$ & $\begin{array}{l}\text { Trench 3, 35-38 cm, } \\
\text { within fire-cracked } \\
\text { rock in Stratum 2 }\end{array}$ & $980+/-40 \mathrm{BP}$ & AD 990-1160 & $-26.3 \mathrm{o} / \mathrm{oo}$ \\
\hline
\end{tabular}

to as late as $\mathrm{AD} 1230-1300$, which corresponds with the approximate beginning of the Toyah period. Because the uppermost layers of the site were not sampled, it is unknown whether the site extends slightly later than this date (no artifacts diagnostic of Toyah times were recovered from the surface of the site). A sample (Beta-262629) taken from the top of Stratum 3, which was repeatedly cut into as the midden accumulated, returned a date of $890-870$ and $850-780 \mathrm{BC}$. The span of time between this date and the earliest date from the midden (Beta-262627) is in excess of a thousand years, but additional investigation at the site is necessary before it can be concluded that there was in fact an occupational hiatus during this time.

Based on the stratigraphic profiles together with radiocarbon evidence, a significant portion of the site's history can be reconstructed. Perhaps as early as AD 420-610 (ca. 1530 BP), corresponding with the later portion of the Late Archaic (see Chapter 2), inhabitants of the upper
San Saba River Valley began digging shallow pits into ground surface. These pits accommodated cooking fires for the purpose of processing mussel shells that were being extracted from the nearby San Saba River. Limestone cobbles, collected nearby, were either used to line these pits, or were heated and then added to the pits to provide a lasting source of heat. Pits were probably covered with earth, and then uncovered after their contents had cooked. In the process, fire-cracked rock accumulated along with ashy soil and the remains of the animals that were processed. These included mollusks as well as some game. No intact rock-lined features were observed in trench profiles, and based on available data it is unlikely that large-scale roasting features are present at this site. This process was repeated over a span of time nearly a thousand years (at least), resulting in the gradual build-up of dense accumulations of burned, fire-cracked rocks, processing tool debris, and faunal remains. 


\section{Stone Tools}

A wide array of chipped stone tools were recovered from D Herd, reflecting a diversity of activities including some (minor) tool production, tool refurbishing, and resource processing (Table 3-4). Only three projectile points were recovered from D Herd (Figure 3-15). One of these is a probable Edgewood or Ellis, common in Central Texas and dating to the Transitional Archaic period (ca. AD 300-700; Turner and Hester 1993; Figure 3-15A). The other two cannot be identified. One (Figure 3-15B) is missing its distal tip and shows signs of having been reused as a scraper around the notched shoulders. The remaining point (Figure 3-15C) has a contracting stem, narrow shoulders, and is unfinished. Based on the low number of points recovered from this site, it is reasonable to conclude that game hunting was not a significant activity here.
Tools used for general processing activities include a number of utilized flakes, bifaces, and unifaces. Some bifaces were broken in the process of manufacture, suggesting that this activity also took place nearby (Figure 3-16). Additional evidence for on-site tool manufacture comes from the flake cores; flakes suitable for use as expedient tools were removed from these, and would have been useful for scraping, cutting, and other processing-related tasks.

After examining the kinds of artifacts recovered from D Herd, the range of activities that were carried out here appear surprisingly restricted in nature. At least for the period of midden accumulation, baking mollusks from the river and, to a lesser degree, terrestrial game, seems to have been the predominating activity. Some tool production took place here, indicating

Table 3-4. Lithic artifacts from D Herd.

\begin{tabular}{|l|c|c|c|c|c|c|c|c|}
\hline Provenience & $\begin{array}{c}\text { Projectile } \\
\text { Point }\end{array}$ & Bifaces & Blades & Unifaces & $\begin{array}{c}\text { Utilized } \\
\text { Flakes }\end{array}$ & Cores & Debitage & Total \\
\hline Surface & 1 & 4 & & 1 & & 1 & & $\mathbf{7}$ \\
\hline Tr. 1, Lv. 1 & 1 & 3 & & & 2 & 1 & & $\mathbf{7}$ \\
\hline Tr. 1, Lv. 2 & & & & & 1 & 2 & 23 & $\mathbf{2 6}$ \\
\hline Tr. 1, Lv. 3 & & 1 & 1 & & & & 1 & $\mathbf{3}$ \\
\hline Tr. 1, Lv. 4 & & & & 2 & & 13 & $\mathbf{1 5}$ \\
\hline Tr. 2, Lv. 1 & & 1 & & & & & 4 & $\mathbf{5}$ \\
\hline Tr. 2, Lv. 2 & & 1 & & & 2 & & 4 & $\mathbf{7}$ \\
\hline Tr. 2, Lv. 3 & & & & & & 10 & $\mathbf{1 1}$ \\
\hline Tr. 2, Lv. 4 & & & & & & & 4 & $\mathbf{4}$ \\
\hline Tr. 3, Lv. 1 & & & & & & 6 & $\mathbf{6}$ \\
\hline Tr. 3, Lv. 2 & & & & & 1 & & 5 & $\mathbf{6}$ \\
\hline Tr. 3, Lv. 3 & & & & & & 5 & $\mathbf{9}$ \\
\hline Tr. 3, Lv. 4 & & & & & & 3 & $\mathbf{3}$ \\
\hline Tr. 4, Lv. 1 & & 1 & & & 1 & & 8 & $\mathbf{1 0}$ \\
\hline Tr. 4, Lv. 2 & 1 & 1 & & 1 & & & 23 & $\mathbf{2 6}$ \\
\hline Tr. 4, Lv. 3 & & & & & & & 7 & $\mathbf{7}$ \\
\hline Tr. 4, Lv. 4 & & & & & & 12 & $\mathbf{1 2}$ \\
\hline Tr. 4, Lv. 5 & & & & & & & 2 & $\mathbf{2}$ \\
\hline Tr. 5, Lv. 1 & & 1 & & & 1 & & 14 & $\mathbf{1 6}$ \\
\hline Tr. 5, Lv. 2 & & & & 1 & & 23 & $\mathbf{2 4}$ \\
\hline Tr. 5, Lv. 3 & & & & & & 2 & $\mathbf{2}$ \\
\hline Totals & $\mathbf{3}$ & $\mathbf{1 8}$ & $\mathbf{1}$ & $\mathbf{2}$ & $\mathbf{1 1}$ & $\mathbf{4}$ & $\mathbf{1 6 9}$ & $\mathbf{2 0 9}$ \\
\hline
\end{tabular}




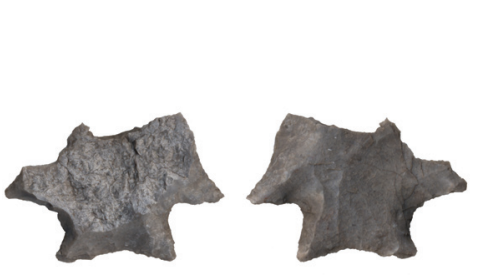

A

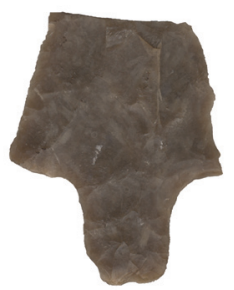

B
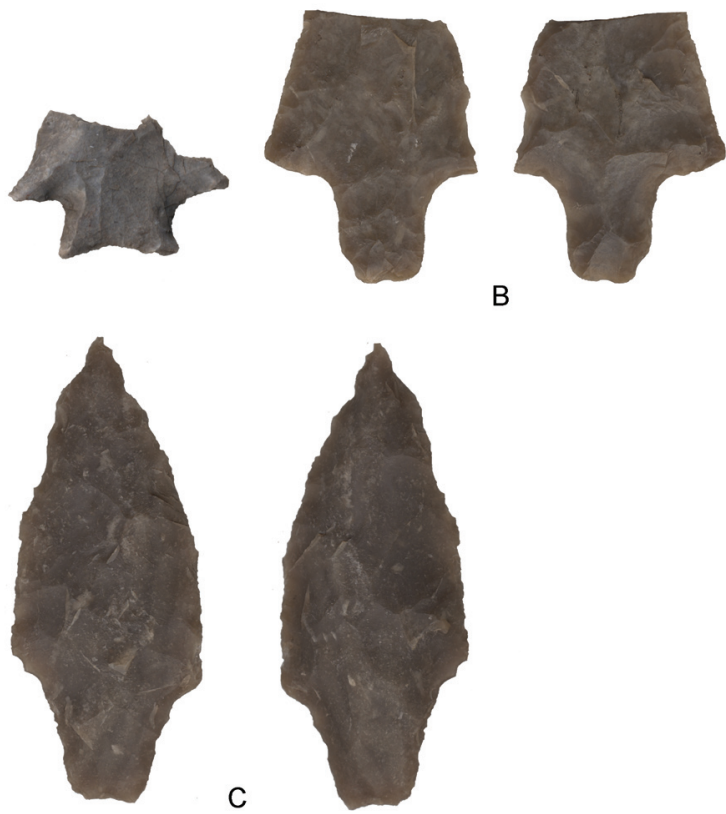

C
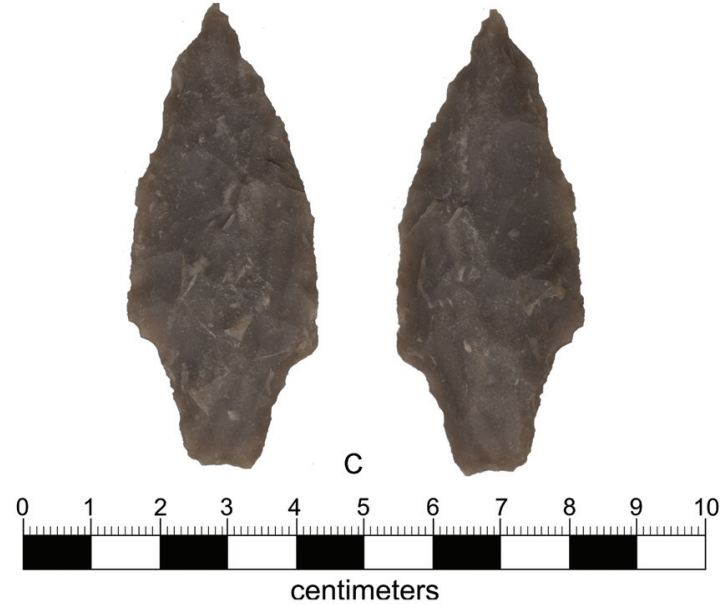

Figure 3-15. Points recovered from D Herd, including a probable Edgewood or Ellis point from Trench 1, Lv. 1 that is heavily burned (A), an untypable fragment missing its distal tip from the surface (B), and an untypable, probably unfinished point from Trench 4, Lv. 2 (C).

that this site was not utilized exclusively for cooking food, but that a variety of activities occurred. It was anticipated prior to excavation that some evidence for occupation would also be found, particularly beyond the margin of the burned rock midden. However, the profile of Trench 4 shows Stratum 2 to be sharply trailing off in thickness, and the lithic recovery from Trench 5 was markedly lower than in other trenches. Clearly, additional excavations are needed to firmly disprove that residence occurred beyond the margins of the midden, but preliminary evidence suggests that it did not. Another point of interest is that so few projectile points were recovered from this site.
Although no truly standardized recovery was attempted, the fact that only three projectiles were recovered during work here is taken as further evidence of the site's focus on riverine resources.

Based on stratigraphic and dating information, intact timeordered deposits are clearly present at D Herd and additional information could easily be recovered by future work at the site. Current evidence seems to support the proposition noted earlier (see Chapter 2) that the end of the Late Archaic and the early part of the Late Prehistoric constitute a moreor-less continuous adaptation in many regions. One example of the kinds of issues that could be addressed includes efforts at fine recovery of botanical remains from the site's ashy sediments. Additionally, more extensive excavation in off-midden areas

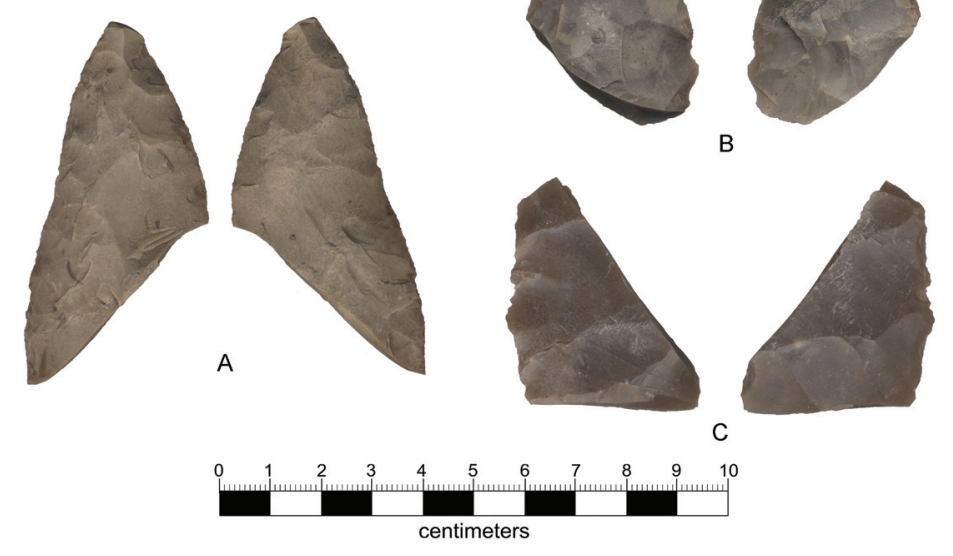

Figure 3-16. Bifaces, broken in manufacture, from Trench 1, Lv. 1 (A), Trench 4, Lv. 2 (B), and Trench 2, Lv. 3 (C). 
could confirm or refute the current interpretation that residence was not a significant activity here. Because the site's strata are demonstrably intact and chronologically ordered, any future excavation should emphasize absolute dating as a way to reconstruct events in the site's history. This focus is particularly important considering the apparent dearth of time-diagnostic artifacts. Finally, as with other sites on the Herd Ranch, D Herd stands to contribute most to the overall understanding of local and regional prehistoric events when considered in conjunction with other sites, and types of sites, that occur here. In particular, these should include demonstrably residential sites.

\section{MN69: the C Herd Site}

Named after Herd family member Chesly Herd, the C Herd site, 41MN69, is a multi-component prehistoric site with a historic component located just south of RM 864. The site is situated along the first terrace of the San Saba River; terrain here is slightly undulating and gradually declines in elevation to the south towards the river as the leading edge of the terrace slowly weathers and erodes away (Figure 3-17). Site boundaries are defined to the south by the river, to the east by the Herd Ranch property line, to the north (arbitrarily) by RM 864, and to the west by an erosional drainage that leads into the San Saba River channel. This large area measures approximately $740 \mathrm{~m}(\mathrm{~N} / \mathrm{S})$ x 475 $\mathrm{m}(\mathrm{E} / \mathrm{W})$. Soils here are mapped as Uvalde silty clay loam (UaB) and Frio Soils (Fr). Depths of the alluvium extend as much as a meter in low-lying areas of the site, while elevated portions expose clayey sub-soil deposits that likely date to the Pleistocene era and predate human occupation of the region. Prehistoric artifacts are present on the surface across the entire extent of the site area, and a historic scatter is limited to the site's southwest corner.

When recording the site, CAS archaeologists inspected the ground surface along the terrace, looking for any artifact patterning that might indicate smaller site boundaries. Cultural materials, including broken chert debris and tools as well as fire cracked rock, litter the ground from one end of this open pasture to the other. (It is possible that additional work, with the aid of precise mapping instruments and statistical analyses, can demonstrate distinct clusters of artifacts indicating activity areas or discrete visitations.) Artifacts indicate that a full range of activities took place here, probably over a span of many millennia. Items that were collected during the CAS survey include broken bifaces in various stages of manufacture (Figure 3-18A, C) that exhibit varying skill levels, and a weathered, stemmed arrow point (Figure 3-18B). The arrow point can not be identified, but it shows probable impact damage at its distal tip, suggesting that it was broken afield and then brought back into a

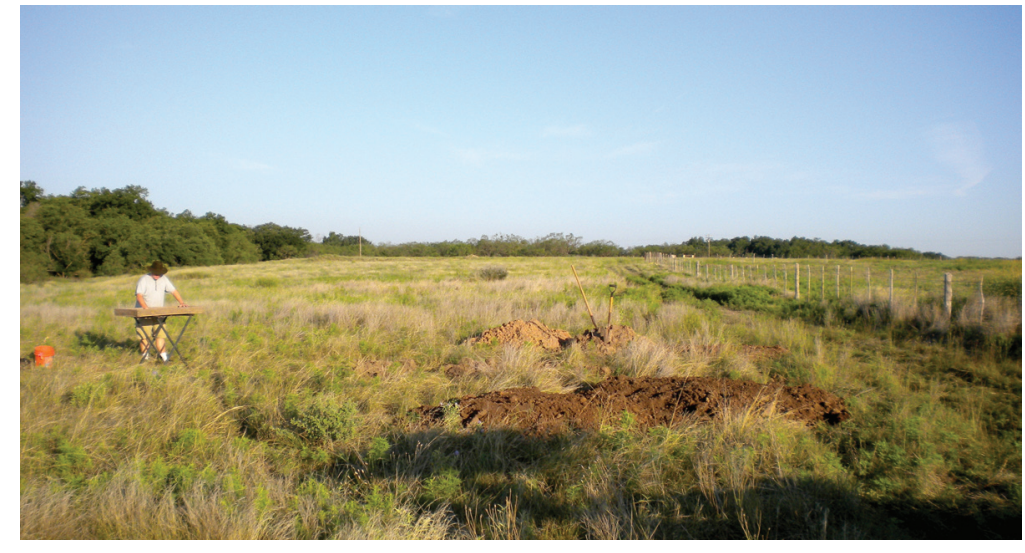

Figure 3-17. Overview of C Herd, 41MN69, looking west. The leading edge of the alluvial terrace follows along the tree line, at left. CAS archaeologist Spencer LeDoux screening dirt from one of the backhoe trenches at the site. 


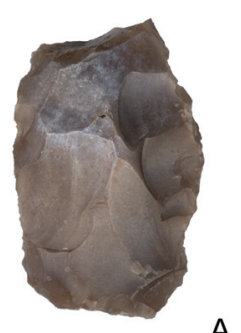

A
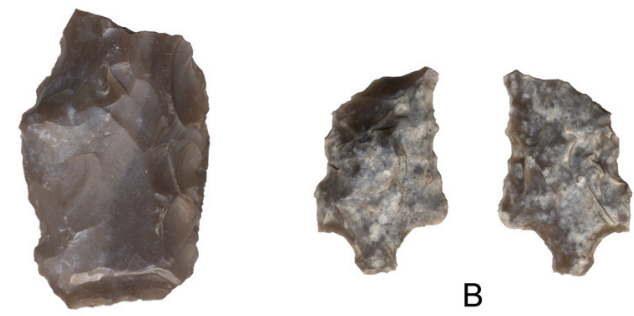

B
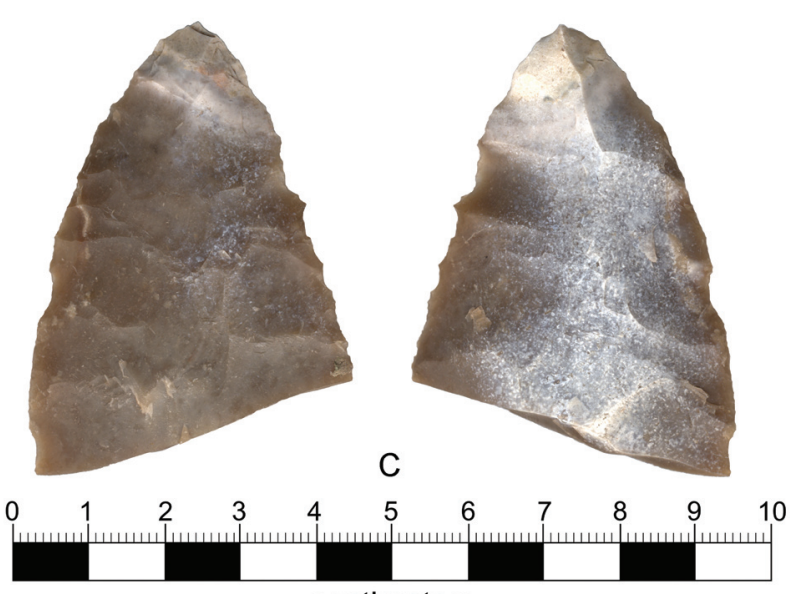

centimeters

Figure 3-18. Artifacts collected from the surface at $\mathrm{C}$ Herd, including crudely fashioned and unfinished biface (A); weathered, untyped arrow point showing possible impact damage (B); and distal biface fragment that was broken during manufacture (C).

residential context for reworking. In addition to these items, the basal fragment of a Clovis point was collected from the site by Chesly Herd in early 2009 , indicating the great time depth that is represented here (see Figure 2-3).

In addition to surface lithics and scatters of fire-cracked rock, C Herd contains discrete cultural features that reveal the kinds of activities that were performed at this locale during its long history of occupation. One of these is a cluster of at least five bedrock mortars; deep, circular features that were pecked and ground into an exposure of limestone bedrock close to the river (Figure 3-19). Bedrock mortars have been reported at sites in the Lower Pecos region (Shafer and Zintgraff 1986), in Reagan and Crockett Counties in far western Central Texas (Riemenschneider 1994; Riemenschneider and Turpin 1998), in Mills and
San Saba Counties in northCentral Texas (McElroy 1940), and recently at a number of sites in Blanco and Kimbell Counties (Hixson 1997; Saner and Hixson 1999). Site 41MN4, recorded in 1932 near the intersection of Rocky Creek and the San Saba River, also reportedly has mortars in exposed bedrock outcrops (Texas Archeological Sites Atlas, 41MN4), and additional mortars have been reported along the San Saba, downstream from C Herd (John Arnn, personal communication, 2009). These features are not uncommon, yet represent a significant amount of labor spent processing specific resources. Saner and Hixson (1999) note the common presence of these features close to water, and suggest that some forms were used to process plant resources that might have been high in tannic acids, like acorns, and that would require frequent leaching.

A dense, localized accumulation of burned and fire-cracked rock was noted at $\mathrm{C}$ Herd in addition to the bedrock mortars. This feature is located on top of the terrace, close to RM 864 (Figure 3-20). An unpaved ranch road runs directly over the top of this small burned-rock midden, leaving it somewhat spread out and deflated. Nevertheless, the feature is approximately two feet high (ca. $60 \mathrm{~cm}$ ), and spans as much as ten meters across at its base. Although the midden was not tested, it still represents evidence of discretely patterned activity area with the potential to provide important information about prehistoric behaviors in the region. If the midden accumulated through a single cooking event, its 


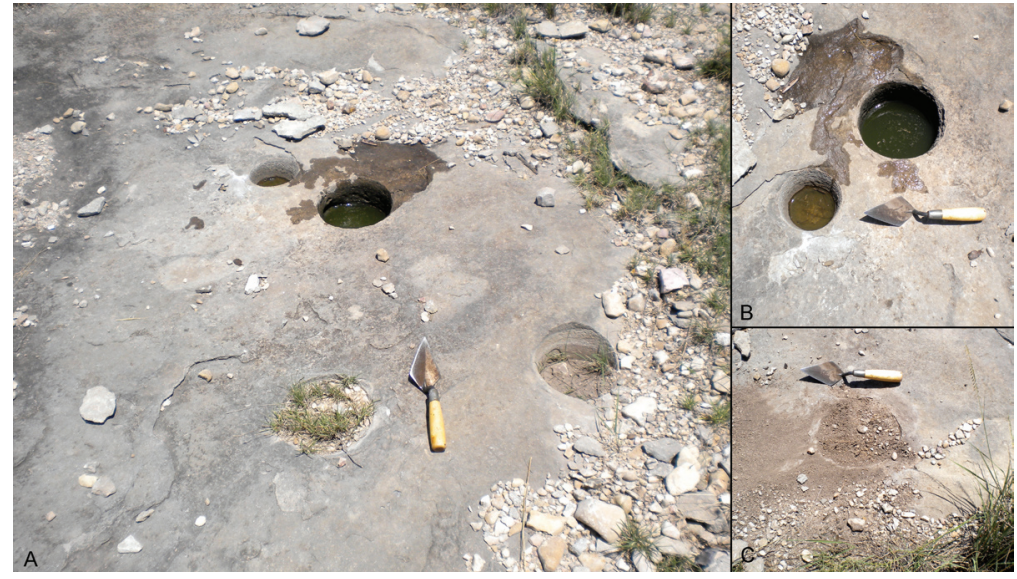

Figure 3-19. Bedrock mortars at C Herd. At least five are present here, including four in a cluster (A), and a fifth one (C) located nearby. (B is a different vantage of two shown in image $A)$.

temporal context might be precisely determined through absolute dating. Additionally, excavation and sampling of feature contents could potentially yield dietary information about the resource(s) processed here.

Along with the ground surface inspection six backhoe trenches were dug to test the site for buried deposits. These were spaced evenly east to west across the site area, and were placed on top of the slightly elevated knolls and in the intervening low-lying swales (Figure 3-21). Clearly, discrete features and artifact clusters are present at the site. However, because of the uneven topography of the landform and the fact that at least some of this terrace is deflated, it was not clear from the ground inspection that the site has potential for buried deposits. These trenches were excavated to test for such deposits.

As at D Herd, backhoe trenches were excavated in one foot levels, with dirt from each level piled separately for inspection and screening. At
C Herd, only two buckets from each level were screened; the remaining piles were leveled and sifted by hand for artifacts. Notes were taken regarding the frequency of various cultural remains within each level, and soil characteristics including color and texture were recorded. Based on soil characteristics and artifact content, results indicate that portions of the site contain buried and potentially ordered, intact deposits (Figure 3-22). Deposits were found across the site, but occur in particular in low-lying swales between elevated ridges and knoll tops. Historic remains were noted in the upper couple of levels in Trenches 1, 2, and 3, and included a small number of unidentifiable glass and metal fragments. A buried prehistoric component appears to be present in Trench 1 but does not extend to Trench 2. Buried prehistoric remains were, however, observed from Trenches 3 to 6 ; this deposit is particularly well represented in Trench 3 and slightly less so in Trench 4. Based on strong color and texture differences in trench

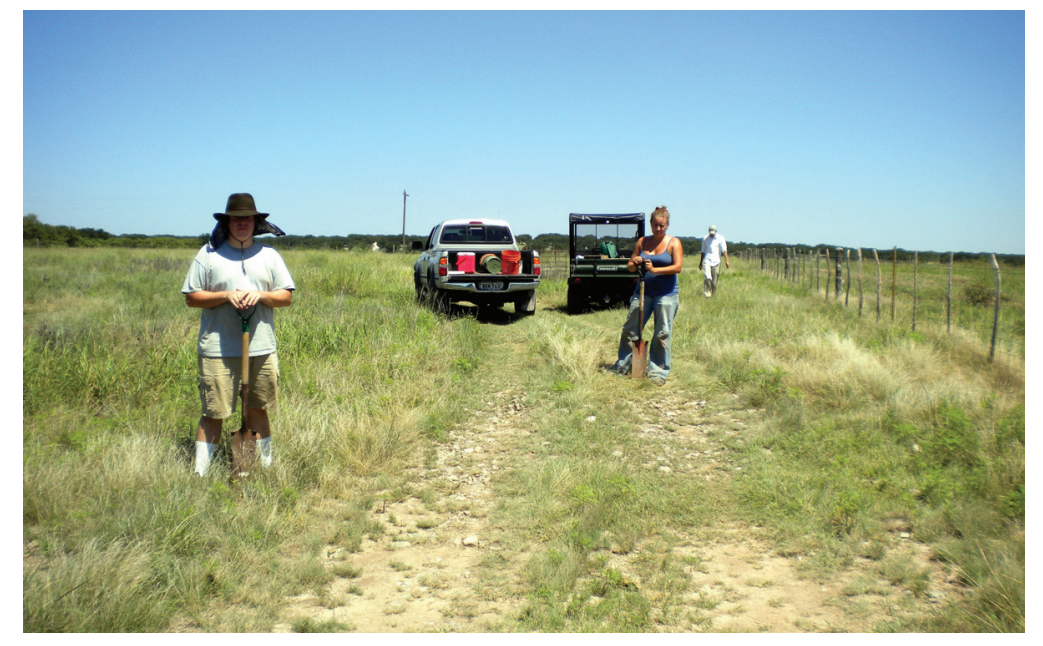

Figure 3-20. Small, deflated burned rock midden at C Herd. CAS archaeologists Spencer LeDoux (foreground) and Sarah Scogin (middle) show change in elevation from the edge to the middle of this feature as a result of the accumulation of burned and fire-cracked rock. 
FIGURE 3-21. REDACTED

Figure 3-21. Map of C Herd showing site boundaries, and feature and backhoe trench locations.

profiles, these two trenches ( 3 and 4 ) also show evidence of possibly stratified remains. Trenches 3 and 4 were the lowest in terms of beginning elevation, and it is likely that these areas have been significantly less eroded than the more elevated portions of the site. Any future excavations that are conducted at this site should focus on these areas in particular, and should be conducted in a controlled fashion that would allow archaeologists to reconstruct more precisely the extent, nature, and content of these deposits.

C Herd covers a large area and contains several discrete components revealing different information about the activities that were carried out here. During prehistoric times, resource extraction and processing occurred, and based on scatters of burned and fire-cracked rock across the surface it is possible that small-scale residence took place as well. Even though much of the site is deflated, it is clear that other areas contain buried and possibly stratified deposits. On the basis of demonstrated spatial patterning, as well as the potential for buried remains to be present, this site has high research potential. 


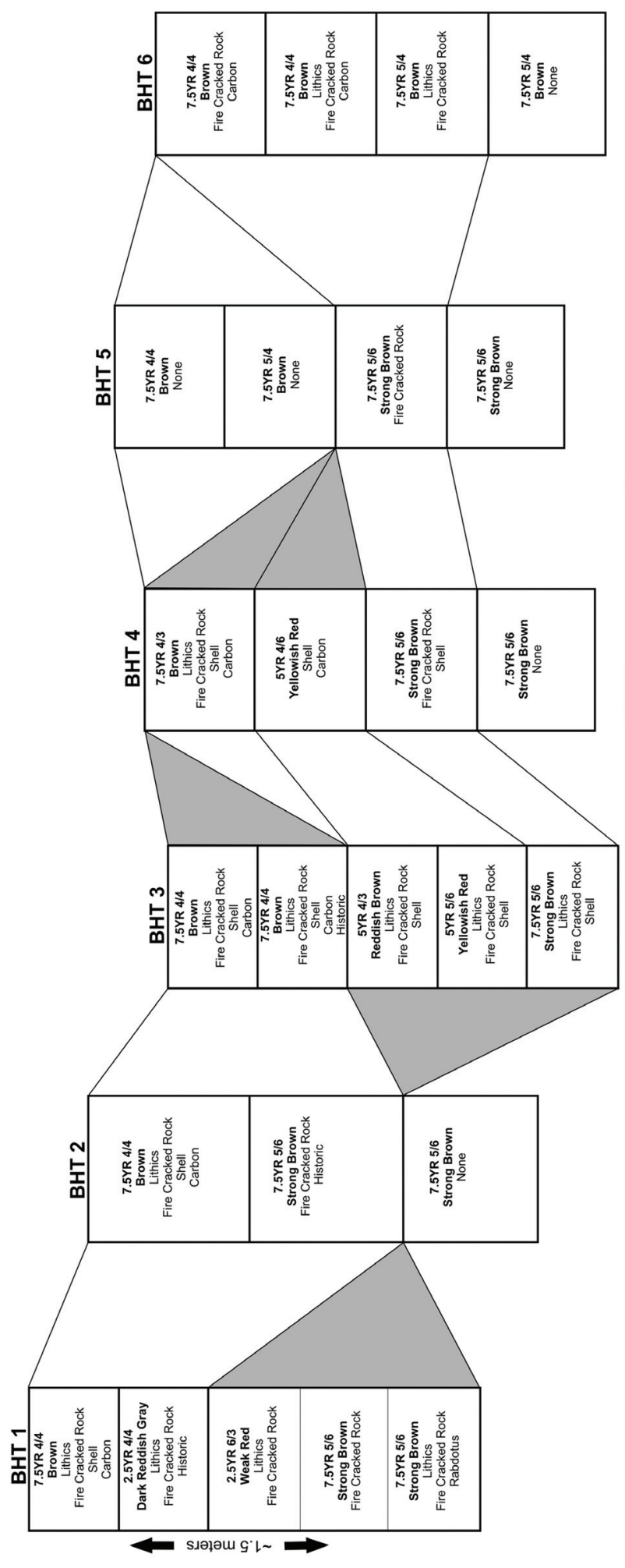

*PART OF FIGURE 3-22. REMOVED

Figure 3-22. Reconstructed cross section of backhoe trenches at C Herd, showing levels containing buried deposits. Color values are from the standardized Munsell color chart. Elevation differences between trenches are approximated. 


\section{MN70: the T Herd Site}

Named after Herd family member, Tevis Herd, the T Herd site, 41MN70, is a historic artifact scatter with a prehistoric component. The site is located in an agricultural field just north of the Herd Ranch entrance and a couple of hundred meters east of D Herd, 41MN68 (Figure 3-23). The site sits on an alluvial terrace with soils identified as Uvalde silty clay loam (UaB). Bedrock is present at approximately $40 \mathrm{~cm}$ below the surface; the shallow depth of bedrock is indicated by a heavy deposit of natural limestone gravel across the surface. When CAS archaeologists visited the site, a scatter of historic and some prehistoric artifacts was visible on the surface. Three shovel tests were excavated, but no discrete or intact buried component was recorded. On the basis of the pedestrian survey and ground inspection, the horizontal extent of the site measures approximately $95 \mathrm{~m}(\mathrm{~N} / \mathrm{S}) \times 78$ $\mathrm{m}(\mathrm{E} / \mathrm{W})$.

Cultural materials observed on the surface consisted of earthen ware sherds, glass fragments, and metal. A fragment of a white porcelain doll was also noted and is now at the Herd family

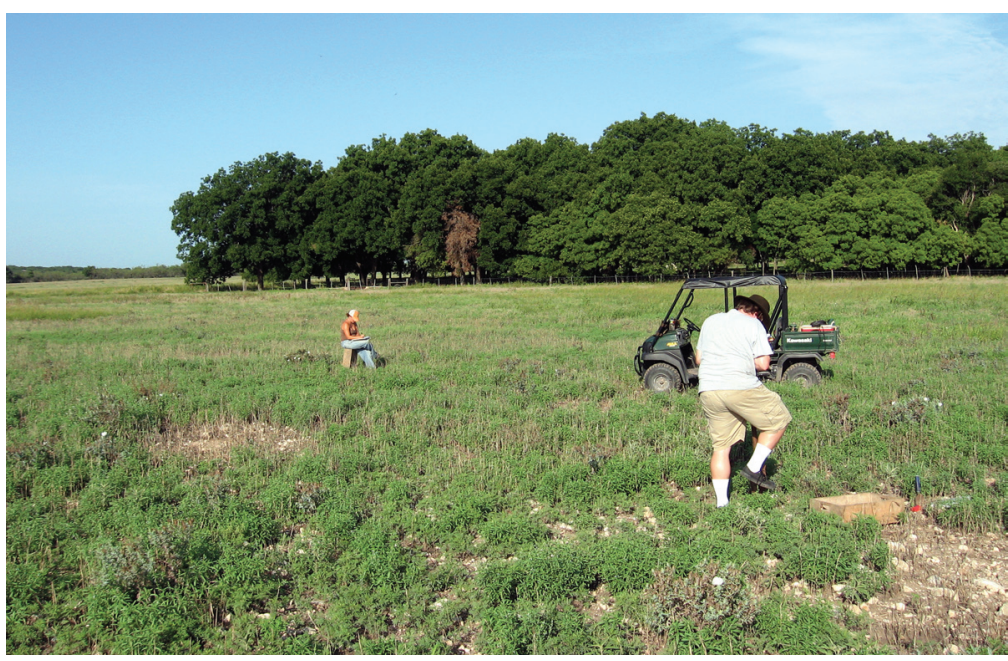

Figure 3-23. Overview of T Herd, 41MN70, looking northwest. CAS archaeologists Spencer LeDoux (foreground) and Sarah Scogin (background) are digging and recording shovel tests. Old growth pecan grove is visible in background. ranch house. Metal artifacts recovered from the site include pieces of rusted and unidentifiable fragments in addition to a horse shoe (Figure 3-24). Prehistoric artifacts were scarce, and included scattered flakes and what might be a tested chert cobble. The site has been repeatedly plowed, and no architectural features were recorded; if any were once present here they have long since been removed. On the basis of finds including the doll fragment and the horse shoe, this site is thought to be a former historic residence, potentially dating from the end of the 19th century into the early 20th century. The possibility exists that the site is slightly older, and could be contemporary with Ft. McKavett, though additional data are needed to support this possibility. In terms of research value, this site holds distinct potential to yield additional information about early historic occupation in western Menard County.

\section{MN71: the JT Herd Site}

Named after Herd family member, JT Herd, the JT Herd site includes a thin scatter of prehistoric lithics and fire-cracked rock. The site is situated near the base of upland terrain that makes up the northern part of the Herd Ranch, but is on alluvial soils associated with the broad terrace along the north bank of the San Saba River. Soils here are identified as Uvalde silty clay loam $(\mathrm{UaB})$; these can be moderately deep, though in this locale topsoil extends no more than $\sim 50 \mathrm{~cm}$ below the surface. The maintenance barn for the ranch and an enclosure are immediately north of the site, and another fenced pasture defines its western edge. The east edge of the site is delineated 


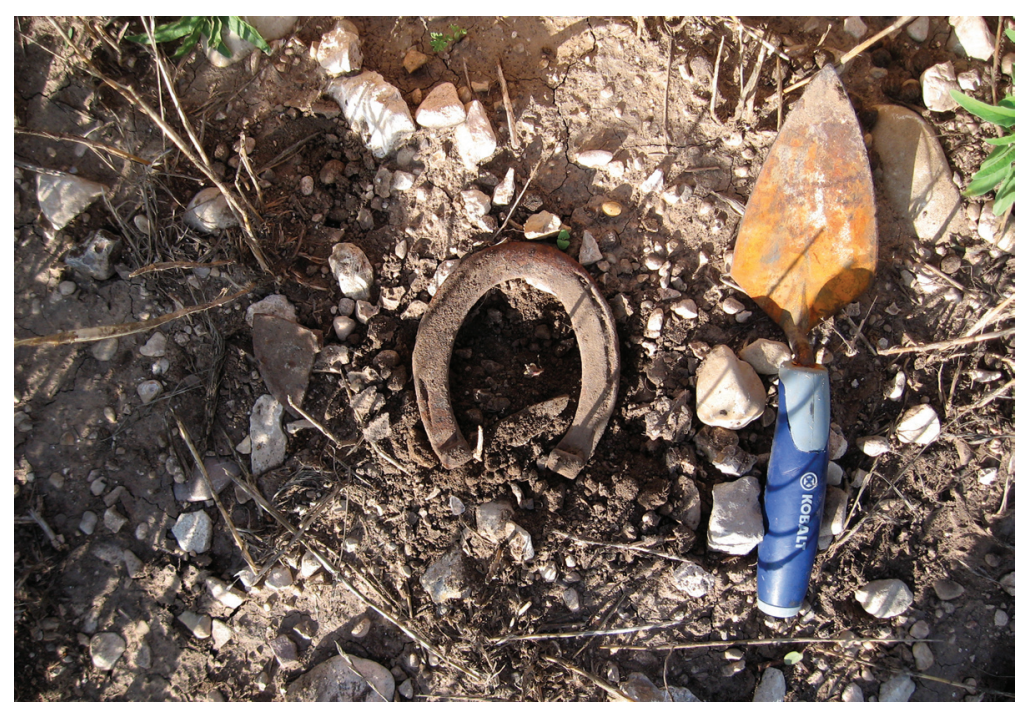

Figure 3-24. Horse shoe from T Herd, 41MN70. A triangular piece of unidentifiable metal is visible immediately to the left of the horse shoe.

by the main entrance drive through the ranch, and the artifact scatter thins out at the edge of the old growth pecan grove located several hundred meters north of D Herd. The JT Herd site covers an area of approximately $124 \mathrm{~m}$ $(\mathrm{N} / \mathrm{S}) \times 100 \mathrm{~m}(\mathrm{E} / \mathrm{W})$. This site is not considered as a lithic procurement area; rather, the locale appears to have been intermittently occupied on a temporary basis in the prehistoric past. Judging from the small number of artifacts present, these occupations seem to have been neither long in duration nor frequent in occurrence.

When CAS archaeologists recorded the site, the ground surface was carefully inspected. A single shovel test was also excavated close to the middle of the site; no buried artifacts were recorded, and sterile, dense clay was reached at $\sim 45 \mathrm{~cm}$. Cultural materials that were observed on the surface included angular, burned rock, interior chert flakes, and an edge-modified stone tool (none of these were collected). In spite of impacts from driveway traffic that covers a small percentage of the site area, approximately $80 \%$ of the site remains intact and in good condition. Based on the kind of artifacts and remains that are present here, the site represents temporary habitation and with additional investigation including extensive excavations, can perhaps be linked with the midden deposit that is present at D Herd.

\section{MN72}

Site $41 \mathrm{MN} 72$ was the final upland lithic scatter that was recorded during this survey. The site is located adjacent to an improved dirt road on relatively flat terrain close to the center of the surveyed alignment, and immediately southeast of 41MN67; this site is within $100 \mathrm{~m}$ of that larger lithic scatter. Soils at this site are identified as Uvalde silty clay loam (UaA); these are very thin here, and bedrock is visible across much of the site (Figure 3-25). Based on a careful ground inspection, the horizontal extent of the site measures approximately $30 \mathrm{~m} \times 30 \mathrm{~m}$. As with other lithic procurement sites in the region, this is an area where outcropping chert resources were exploited intermittently and at a low level of intensity. The site contains a low frequency of artifacts, and those that are present do not appear to reflect occupation.

Due to the thin nature of the soils here, no shovel tests were excavated during the recording of this site. The pedestrian coverage and careful inspection of exposed ground surface revealed a small number (less than 20) of edge damaged and interior chert flakes. No tested cobbles, bifaces, tools, or possible preforms were observed here. The land surrounding the site is slightly deflated, but has remained in good condition. The site's research potential should be assessed in conjunction with other site types in the region. 


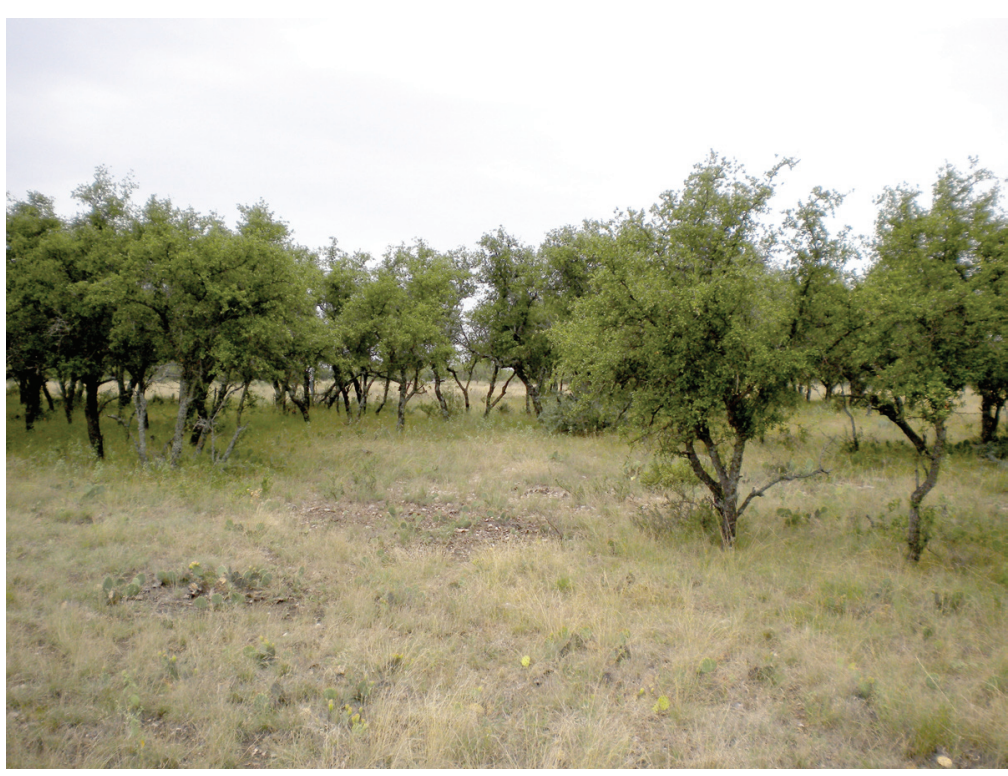

Figure 3-25. Overview of 41MN72. Limestone bedrock can be seen through thin topsoils in areas of low grass cover.

When CAS archaeologists recorded the site, they performed a careful inspection of the ground surface and identified a wide range of artifacts. The site contains multiple pieces of burned rock (Figure 3-27), both interior and cortical chert flakes, and three crudely chipped bifaces. A shovel test was excavated to identify any subsurface deposits, but this was closed at $50 \mathrm{~cm}$ below surface because of the compactness of the sediments, and no subsurface artifacts were noted. Nevertheless, because the site is situated on alluvial soils, the probability that buried remains

\section{MN73: the P Herd Site}

Named after Herd family member, Patty Herd, the P Herd site is located near the entrance to the Herd ranch in the same agricultural field that also contains T Herd (Figure 3-26). The site includes a thin, dispersed scatter of prehistoric lithic debris and burned, fire-cracked rock. The site is located across RM 864 from C Herd, and approximately $300 \mathrm{~m}$ east of D Herd. When CAS archaeologists recorded the site, material visible on the surface extended for approximately $70 \mathrm{~m}(\mathrm{~N} / \mathrm{S}) \times 100$ $\mathrm{m}(\mathrm{E} / \mathrm{W})$. The unpaved entrance drive to the ranch defines the site's southern boundary, while artifacts thin out to the west, north, and east. Soils here are mapped as Uvalde silty clay (UaB); these extend over 50 $\mathrm{cm}$ below the surface, though are quite compressed during particularly dry spells.

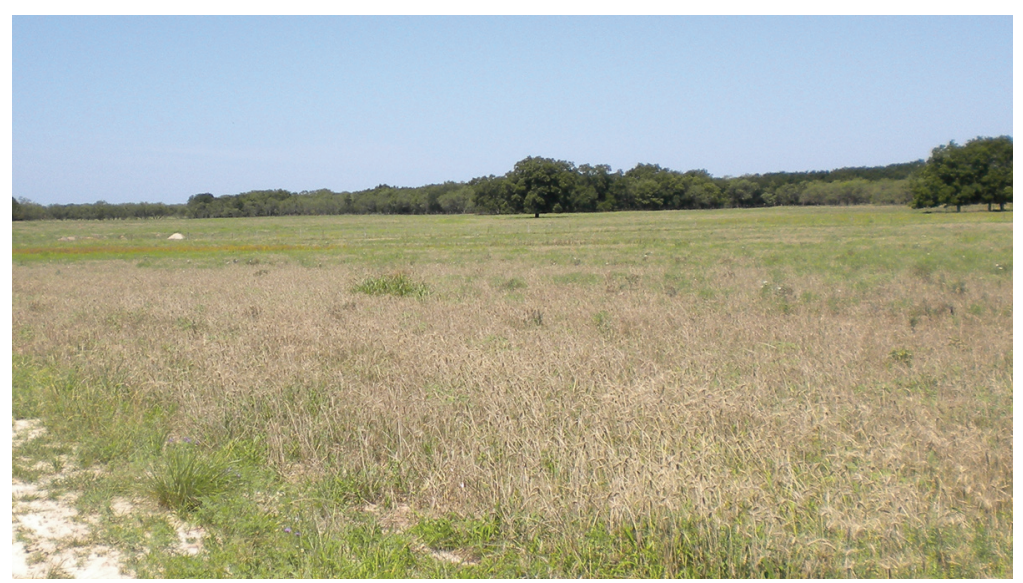

Figure 3-26. Overview of P Herd, 41MN73, looking west. Piles of backdirt from trenching at D Herd are visible in the distant background, and the old growth pecan grove is visible at far right. 


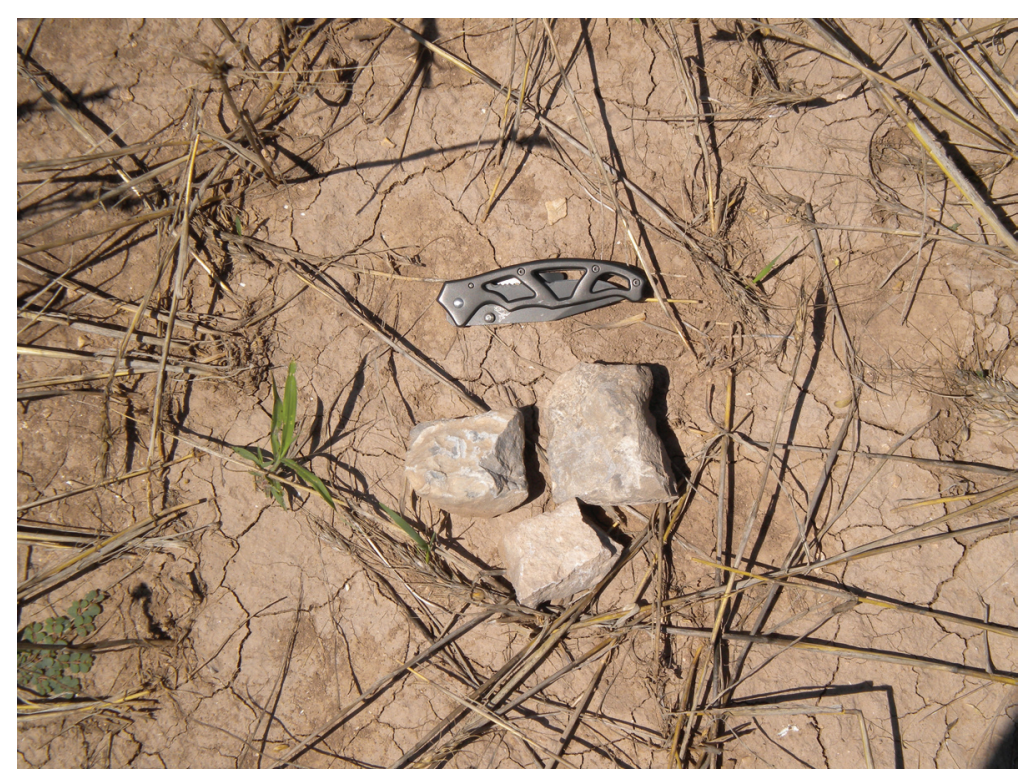

Figure 3-27. Angular, fire-cracked rock from the surface of P Herd. 


\section{Chapter 4}

\section{Conclusions And Recommendations}

The sample of sites documented during the brief survey and archaeological testing conducted across a small portion of the Herd Ranch represents merely a small fraction of the overall number of sites and deposits that are present. Other known areas, if subjected to systematic archaeological testing, are likely to represent extended habitation sites close to or along the San Saba River and its spring-fed tributaries; subsistence extraction and processing localities, perhaps associated with pecan, bison or deer, or riverine resources; and chert extraction sites located in upland settings. Many of these sites are sure to contain significant information pertaining to the prehistory of western Menard County, and would make lasting contributions to the overall understanding of the record of human occupation in this part of Texas. According to the Herd family, Scabtown, the civilian settlement that was closely associated with historic Ft. McKavett, is also located here. The significance of this site cannot be overstated, as it is likely to contain evidence not only of the successful civilian ventures that accompanied frontier military life, but also remains of minoritystatus groups such as women, compliant Native Americans, and other underrepresented and "hard to see" constituencies that made up the cultural fabric of evolving American society in the nineteenth century.

The twelve sites that were recorded represent a variety of activities that were central to prehistoric life in the region. (They also begin to hint at historic occupations in the area, though this period is not represented nearly as strongly as the prehistoric.) The following synopses are based not only on the remains that were recovered or documented during the survey and light testing, but also on information available elsewhere across Central Texas. Three key, interrelated issues are identified that might be of concern to future work in the area: chronology, subsistence practices, and labor arrangements that facilitated adaptations during different prehistoric periods, although others are possible as well.

\section{Chronology}

Based on the artifacts that have been recovered on the surface from different parts of the study area, nearly all prehistoric time periods are represented here. This means that any future work that is conducted should reasonably expect to encounter deposits or remains dating to practically any time period of the Central Texas cultural chronology. At present, only the Late Paleoindian and portions of the Middle Archaic (specifically the Nolan and Travis interval, see Table 2-1) appear absent. The Early Paleoindian period, too, is not well represented, though this is hardly surprising when taking into account the time depth involved and the overall scarcity of remains from this period. Even though Late Paleoindian and Nolan/Travis-period Middle Archaic materials are yet unknown, the potential that they are, in fact, present here should not be 
discounted. A radiocarbon date of ca. 2650 BP was recovered from only $70-73 \mathrm{~cm}$ below the ground surface at D Herd, 41MN68, and yetundated cultural materials were present below this depth (see Chapter 3). This means that there is a very strong likelihood that the broad alluvial terrace that follows along the north bank of the San Saba River contains intact deposits perhaps representing these "missing" time periods, if not others as well.

An important corollary to filling out the local chronology is that specific research questions pertaining to certain time periods will arise, requiring consideration, when configuring plans to address dated deposits. A hypothetical example of this includes the issue of Calf Creek as a specialized regional focus on bison (see Chapter 2 discussion). Both Early Triangular (Middle Archaic, following Calf Creek), and split stem and Martindale (Early Archaic, predating Calf Creek), point types are present in the study area; all of these types have been reported with Calf Creek materials. Future work dealing with this time period (the end of the Early Archaic and early part of the Middle Archaic), then, should address the question of specialized production of Calf Creek materials.

Presently, Calf Creek is included in what Elton Prewitt (1981, 1983) calls the Jarrell Phase of Central Texas chronology. In this system, Calf Creek materials are interpreted as representing a discrete cultural group whose technological style (defined by Calf Creek points, Figure 4-1) can be distinguished from that of other groups. Others (Johnson 1987; Wykoff 1994), however, interpret Calf Creek to reflect a "horizon," or a rapid, wide-spread behavior or pattern having a regional distribution but that co-occurs with other materials. The difference, in this case, between phases and horizons is one of cultural affinity. "Phase" implies a unified cultural group while a horizon is simply a spatially and temporally bounded event or phenomenon that does not necessarily involve ethnic, social, or cultural affiliation. Were Calf Creek to be demonstrably a horizon rather than phase, as most evidence suggests, then archaeologists would need to consider the conditions under which some individuals in prehistoric hunter-gather society in Central Texas (and the larger Southern Plains) specialized in hunting bison while others did not. To this end, other prehistoric periods like Clovis, Folsom, or Toyah, periods that archaeologists know were characterized by specialized hunting of large game, might serve as suitable analogies for modeling divisions of labor and situational specialization in Calf Creek times.

In the context of the occupation record at Herd Ranch, this example is intended merely to illustrate how certain issues are intrinsic to the question of fleshing out local chronologies. Other questions can be developed for other time periods as well, and these ought to be strongly grounded in known or developing issues deriving from nearby or regional datasets.

\section{Subsistence}

Work carried out during this project recovered some (incomplete) evidence for the dietary practices of the prehistoric peoples who lived here, at least for certain time periods. Virtually all of this information came from D Herd as a result of trench excavations in the midden. The presence of clear, well defined bedrock mortars and a small midden of firecracked rock at C Herd, 41MN69, suggest that dietary information can be recovered from this site as well. 

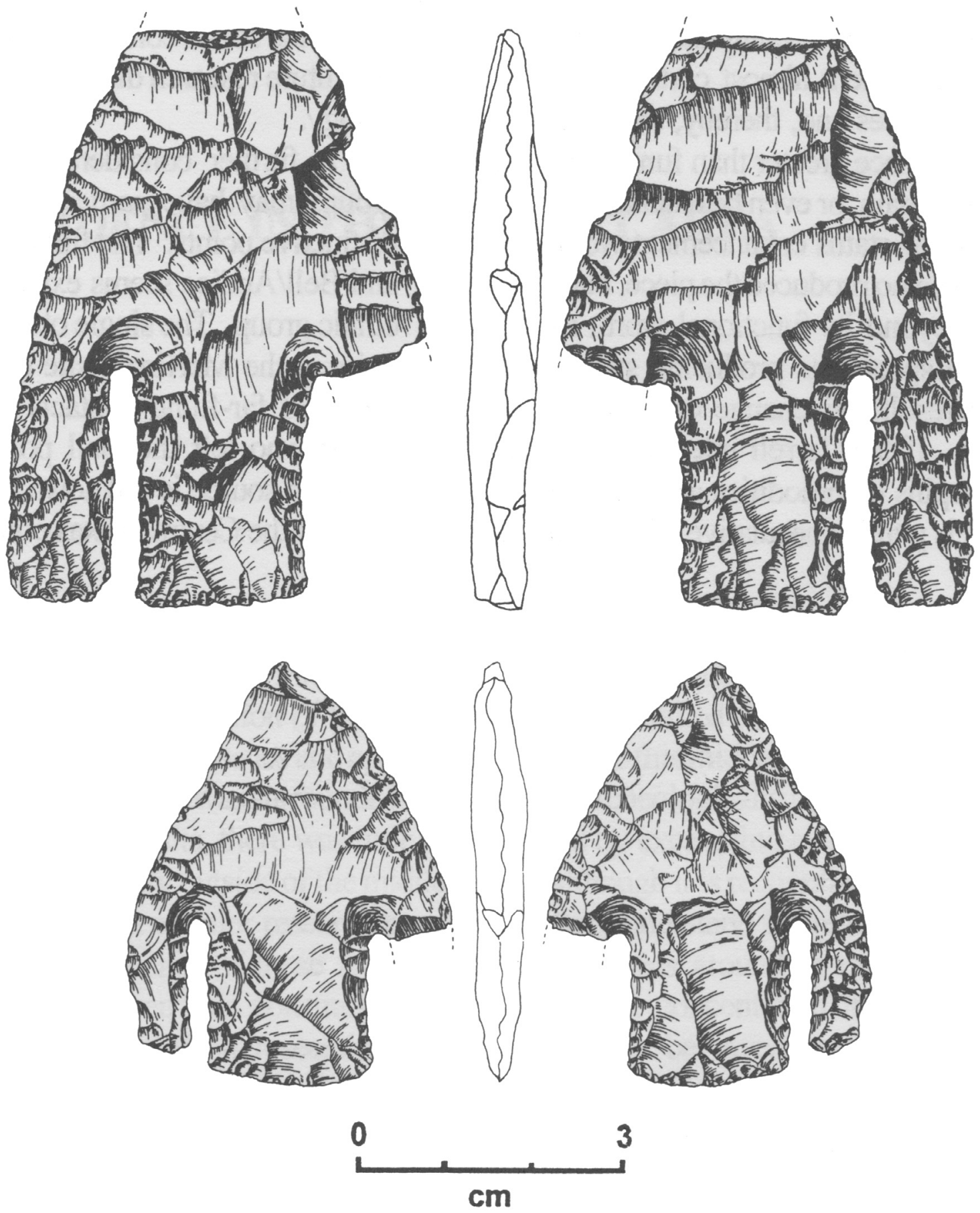

Figure 4-1. Examples of Calf Creek (Bell/Andice) points with their characteristic deep basal notches and broad, triangular blades. These points are commonly believed to represent a specialized bison hunting adaptation, but it is not known whether they always co-occur with other materials or whether they constitute a discrete cultural adaptation. These specimens were recovered from the Gault Site, in western Bell County in Central Texas (after Collins 1994: Figure 41). 
In addition to straightforward excavations for recovering faunal remains, as was conducted at $\mathrm{D}$ Herd and is possible at $\mathrm{C}$ Herd, special sampling to identify different kinds of plant resources that were utilized might also prove useful in the event that future work is carried out here. Specifically, processing bulk sediment samples from stratigraphically-controlled contexts by passing them through increasingly fine-meshed screens, from $1 / 4$ inch to window screen, is one way to recover small remains such as seeds or nut hull fragments that would otherwise pass through standard $1 / 4$ inch mesh. Additionally, soaking bulk samples in water with mild agitation is a common way to recover carbonized fragments for later identification. This process, called flotation, separates samples into two portions, or fractions. The light fraction includes specimens, mostly carbonized, that float to the surface; these can be skimmed off and identified once allowed to dry. The portion that settles to the bottom, called the heavy fraction, can also contain plant remains. Sampling select contexts through flotation, which was not performed on the current project, has long been useful to archaeologists interested in recovering botanical fragments that often times are too fragile to survive being passing through excavation screens, or are too small to be recovered by standard means.

Yet another possible avenue for future research on subsistence involves sampling for chemical residue evidence on burned rocks that might be encountered lining cooking features. Research at the Lino Site (41WB437) in Webb County in South Texas (Quigg et al. 2001) and at the Varga Site (41ED28) in the Canyonlands of Edwards County in western Central Texas (Quigg et al. 2008) has demonstrated how fatty acids, recoverable as lipid residues, specific to large mammals, fish, and certain plant foods can be identified in well preserved contexts. Other methods for reconstructing ancient dietary practices are also available and should be considered in future work at the Herd Ranch, as contexts permit. No matter what techniques are employed, it is clear that developing a greater understanding of subsistence practices would require focused excavation and sampling.

Even though no special recovery techniques were carried out in the current project, a fair amount of information for prehistoric subsistence was collected. A list of taxa identified from D Herd is presented in Table 3-1 and the habitats in which they occur in Table 3-2. These include a range of species common to Menard County: vertebrate mammals consist of deer, bison, deer- or antelope-sized mammal, rabbit, and a canid, perhaps a fox, coyote, or dog. Importantly, invertebrates (gastropods and mussels) were very well represented, which is perhaps not surprising considering the site's proximity to the river. Although no flotation was performed on this project, the old growth pecan orchard near the site suggests that pecan was an important resource in prehistoric times as well. Ample ethnohistoric information exists that detail the importance of pecans to Native American diets, specifically for groups living in and near present-day Menard County. Alvar Núñez Cabeza de Vaca, who was shipwrecked on the Texas Coast in 1528, described how the Mariame would eat pecans for one to two months each fall, and that groves along the lower Guadalupe River would attract non-Mariame groups from up to 120 kilometers away (Hall 2000). Another Spaniard, named Espinosa, described how Payaya, who inhabited an area south of San Antonio along the Medina River, would store pecans in leather sacks and underground pits. Closer to the current study area, sometime between 1683 and 1692, a Jumano named Juan Sabeata explained to Spaniards how "the river which they call Las Nueces is a three day's journey from that place; that there are nuts in such abundance on this river that they 
constitute the maintenance of many nations who enjoy friendship and barter and exchange" (Hall 2000:107). Archaeologist Charles Kelley (1955) long ago identified Juan Sabeata's Las Nueces as the Concho River, and Grant Hall (2000) argues that this account also may describe the stretch of pecans along the Colorado, San Saba, and Leon Rivers.

What special significance is conveyed by a heavy reliance on pecans in prehistoric times? By itself, the answer is probably not very much beyond the easy ability for social groups to provision themselves on a seasonal basis without difficulty. However, archaeological research carried out in similar habitats in eastern North America (Winters 1974) has identified what some call the "triumvirate" of deer, mussels, and nuts. This diet would have been extremely productive from a nutritional standpoint, and could have provided all the necessary nutrients, with the possible exception of Vitamin $\mathrm{C}$, needed to sustain large populations in good health. The fact that mussels, which were harvested in moderate numbers from the San Saba River, and pecans both replenish naturally means that relatively little effort would have been required to meet the food needs of a number of regional inhabitants. Calculating exactly how many individuals could have been sustained on this diet requires much additional data. Nevertheless, future research on regional prehistoric subsistence seems to have the potential to provide information concerning the general population density of the region. Coupled with finer chronological controls, reconstructing fairly detailed demographic profiles seems easily feasible. Minimally, approximately AD 4201300 , conservatively taken as the outside span of time represented by midden and processed mussel accumulation at D Herd (see Chapter 3), can be taken as an age range during which this particular dietary pattern was in effect.

\section{Labor}

In addition to chronology and subsistence, two admittedly broad research topics for Central Texas, important patterns of labor allocation by different members of prehistoric societies that lived in western Menard County are suggested by the available data, and should be pursued in future research. Understanding precisely how different kinds of individuals carry out tasks in any particularly cultural context is often a difficult, if not impossible task. Nevertheless, some patterns in terms of sex- and age-based labor organization have been documented that can be used to formulate models that can be tested with archaeological data.

Divisions of labor based on age and sex have long been noted in historic and contemporary hunter-gatherer societies (Brown 1970; Dahlberg 1981; Hill et al. 1985; Lee and DeVore 1968; Murdock and Provost 1973). In looking at different Native American cooking techniques for instance, Linda Ellis (1997) reviewed over 100 ethnographic and ethnohistoric sources from North America to create an analogous framework for understanding prehistoric burned rock middens in Texas. Every one of the 14 different cooking techniques she identified in the literature involved some division of labor by age or sex. Archaeologists commonly presume that labor was similarly organized in prehistoric societies as well (e.g., Sassaman 1992; Waguespack 2005:668), and a few approaches have been developed to recognize the labor of different kinds of individuals based on patterns in the material record.

One approach to ascribing tasks to a specific sex is called task differentiation; this involves using ethnographic or historic examples as analogies for archaeological cases. In her study of the Plains Hidatsa, Janet Spector (1998) notes that women collected and processed all 
food and natural resources and constructed and maintained the structures. Men killed bison during the summer and also conducted rituals that accompanied these hunts. Hidatsa women worked within a one-mile radius of camp, and more often immediately around the lodge. Men conducted their work at much greater distances. This study provides the basis for spatial frameworks that can in turn be used to formulate hypotheses about where certain activity areas may occur. Such studies can also be used to infer which tools were used in those tasks, and thereby build an inventory that arguably reflects men's or women's work. Another common approach involves analyzing burials, burial contexts, and grave goods. Bioarchaeological analyses of sexed individuals can identify evidence of wear or repetitive motions that accrues through sexually ascribed tasks. Larsen (1997), for example, observed patterns of wear on teeth suggesting that women in some societies were involved in chewing plant fibers for basket-making or hide for making clothing or structures. In the American Southwest, Marsha Ogilvie (2005) analyzed 199 femora from 139 individuals representing Late Archaic foragers, Late Archaic-to-Early Agricultural part-time agriculturalists, and agriculturalists from the Pottery Mound site, all in the greater Southwest United States. She considered the effects of the transition from foraging to established agricultural practices on skeletal structure and noted that, as agriculture became important, men continued to be highly mobile in hunting but that women's degree of locomotion steadily decreased as their work arenas shifted gradually to the domestic sphere. Given sufficient population sizes, studies such as these can help archaeologists understand aspects of labor divisions that can illuminate patterns in the material record.

Even while exceptions exist, some patterns of sexual labor divisions have been documented cross-culturally that can be used to understand at least some archaeological cases. George Murdock and Caterina Provost (1973) sifted through over a thousand observations, accounts, descriptions, and narratives of 185 societies from around the world to record the frequency with which fifty "technological" tasks (identified by them) were carried out by men, women, or both. The result is an "index" that measures the strength of association between a certain task and sex. Although their study focused on men's work, their values can also be used to calculate the links between a task and women's work. When graphed (Figure 4-2), certain tasks are clearly performed always or almost always by one sex or the other, while others are carried out in ways that make it difficult for archaeologists to recognize sexed labor divisions.

This exercise is important for modeling prehistoric tasks that would have been important in the study area; preparing vegetal foods, cooking, water fetching, and gathering of vegetal foods are all strongly associated with women, while hunting large land fauna is men's work. Using this framework to understand specific features and deposits in the Herd Ranch, one can argue that the bedrock mortar features recorded at $\mathrm{C}$ Herd, if used to pound and grind nuts or seeds, were the result of labor intensive activities carried out exclusively by women. Likewise, the dense accumulation of burned and fire-cracked rock at D Herd, representing intensive cooking of mussels plus at least some other foodstuffs, is also most likely the product of predominantly women's labor. At this particular site, where absolute dates are available, a stable pattern of labor allocation by sex that spans almost a thousand years (ca. AD 420 to 1300) can be proposed, spanning the later part of the Late Archaic and including the Austin period of the Late Prehistoric. 


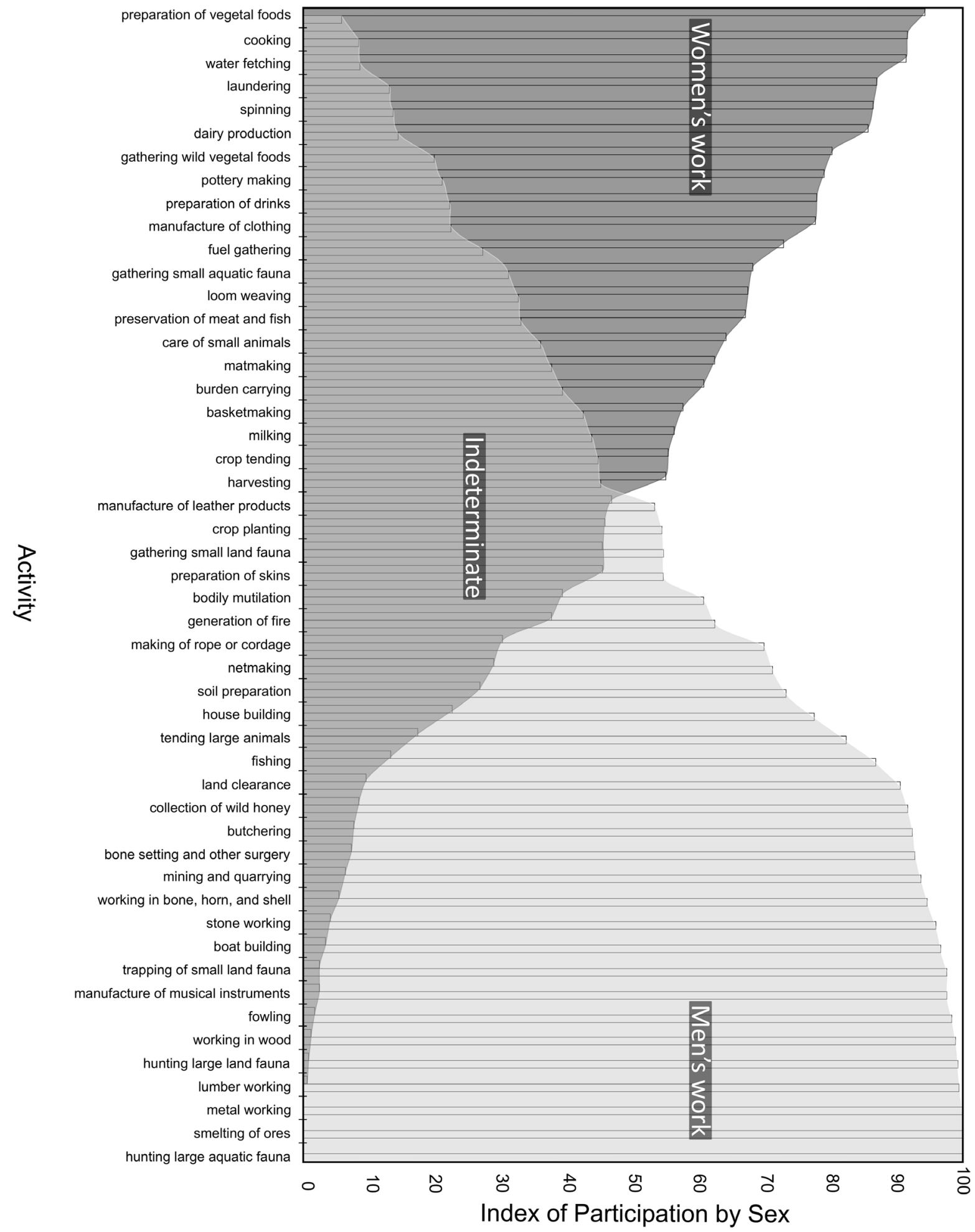

Figure 4-2. Index of cross-cultural participation in certain tasks by sex. Tasks at the bottom are strongly associated with men's work, while those at top are associated with women's work. Tasks toward the middle of the diagram tend to be carried out more or less equally by both sexes. Hunting large terrestrial fauna, such as bison, falls to the bottom, while gathering and preparing vegetal foods, like pecans, is almost exclusively women's work (from Murdock and Provost 1973). 
What occurred that might have interrupted this well established pattern of sex-based divisions of labor? The Toyah period begins around AD 1250-1300 (see Chapter 2), and this period is commonly understood to have included a heavy focus on bison (large game) hunting. Although uppermost levels of D Herd were not sampled, as these occur in the plow zone, a model to be tested in the future involves an abrupt change or alteration to existing traditions of dietary adaptation and labor that comes about with the emergence of intensive, focused bison exploitation. To be sure, other pursuits would have remained important as well. Still, earlier research describes how groups of hunters traveled farther and farther away from residential bases in pursuit of wandering herds (see Chapter 2). One plausible scenario for explaining the occupation history of this site is that local settlement patterns were disrupted at this time as labor requirements for hunting and processing bison changed dramatically, forcing social groups to uproot their residential camps in pursuit of new important dietary staples that were also economic resources for exchange.

\section{Final Recommendations}

The foregoing discussions draw from empirical data recovered from the CAS survey and testing of twelve newly recorded sites in western Menard County, and consider how emergent patterns might be further developed and tested in the case of future work. In any event, it is clear that the present understanding of the prehistoric record of this area is seriously lacking, though promising. Given this current state, only a few meaningful conclusions can be drawn concerning the potential research value of any of the recorded sites. These are as follows.
1) Each site needs to be considered together with available data from other sites. By itself, no site recorded during this project contains the fullest inventory of data concerning past lifeways in the region. This is true for every time period that has so far been documented in the study area.

2) Several sites recorded during this project (41MN68 to 41MN71, and 41MN73) have intact, perhaps extensive deposits that hold the potential to provide new and meaningful information about the region's prehistoric record. Additionally, even the apparently "ephemeral" sites located in upland settings (41MN62 to 41MN67, and 41MN72) contribute meaningfully to the larger picture of human adaptation in the region. Although these sites, when taken individually, might lack aspects of key information (such as time-diagnostic materials or a diversity of technological data), together they represent aspects of prehistoric adaptation in the region that are not duplicated at other sites. As a group, then, they also have the potential to yield new information about regional cultural developments.

3) Any impacts stemming from development that are foreseen or intended to any of these sites should be avoided if at all possible. If avoidance is not possible, then a detailed, robust framework for understanding the prehistoric and historic record(s) of the region should be developed that draws not only on information available from the study area, but that also integrates data bases from other surveys in Menard and neighboring counties representing the greater West-Central Texas region. Additionally, site-specific research programs should be developed for each site that will be impacted that are informed by the region-wide framework but that are tailor-suited specifically to the site(s) to be impacted. 


\section{References Cited}

Adams, Karen R.

2002 Appendix 4b: Archaeobotanical Remains from 41CA13 (the Bear Branch Site), a Prehistoric Rock Ring Midden in Callahan County, Central Texas. In Data Recovery at the Bear Branch Site (41CA13), Callahan County, Texas, by Paul Katz and Susana R. Katz, pp. 156-166. PRIAM Project No. 9906. Report submitted to the USDA Natural Resources Conservation Service, on file with PRIAM, Panhandle, TX.

Alley, William M.

1984 The Palmer Drought Severity Index: Limitations and Assumptions. Journal of Climate and Applied Meteorology 23:1100-1109.

Arnn, John Wesley, III

2005 Chronology, Technology, and Subsistence: Is that All There Is? In The Council of Texas Archeologists Newsletter 29(2), pp 17-28.

2007 Transformation and Persistence of Indigenous Cultural Identity During the Early Colonial and late Prehistoric Periods in Texas. Unpublished Ph.D. dissertation, Department of Anthropology, University of Kentucky, Lexington.

2010 Regional Identity and Interaction in Texas (A.D. 1300 to A.D. 1700): The Toyah/Tejas Social Field. Submitted to the Bulletin of the Texas Archeological Society, manuscript in press.

Bement, Leland C., Ernest L. Lundelius, and Richard A. Ketcham

2005 Hoax or History: A Bison Skull with Embedded Calf Creek Projectile Point. Plains Anthropologist 50:221-226.

Brown, Judith K.

1970 A Note on the Division of Labor by Sex. American Anthropologist 72:1073-1078.

Bureau of Economic Geology

1981 Geologic Atlas of Texas, Sonora Sheet. University of Texas, Austin.

Black, Stephen L.

1986 The Clemente and Herminia Hinojosa Site, 41JW8: A Toyah Horizon Campsite in Southern Texas. Special Report 18. Center for Archaeological Research, The University of Texas at San Antonio.

1989 Central Texas Plateau Prairie. In From the Gulf Coast to the Rio Grande: Human Adaptation in the Central, South, and Lower Pecos Texas, edited by Thomas R. Hester, Stephen L. Black, D. Gentry Steele, Ben W. Olive, Anne A. Fox, Karl J. Reinhard, and Leland C. Bement, pp. 17-38. Research Series No. 33. Arkansas Archeological Survey, Fayetteville. 
Black, Stephen L. (cont.)

1995 Archeological and Ethnohistorical Background. In Archeological Investigations at the Loma Sandia Site (41LK28): A Prehistoric Campsite in Live Oak County, Texas, Vol. 1, by Anna Jean Taylor and Cheryl Lynn Highley, pp. 31-45. Studies in Archeology No. 20. Texas Archeological Research Laboratory, The University of Texas at Austin.

Black, Stephen L., and A. Joachim McGraw

1985 The Panther Springs Creek Site: Cultural Change and Continuity within the Upper Salado Creek Watershed, South-Central Texas. Archaeological Survey Report 100. Center for Archaeological Research, the University of Texas at San Antonio.

Blair, W. Frank

1950 The Biotic Provinces of Texas. Texas Journal of Science 2(1):93-117.

Boton, Herbert E.

1970 Texas in the Middle Eighteenth Century: Studies in Spanish Colonial History and Administration, volume 3. Originally published in 1915. University of California Publications in History, University of California, Berkeley.

Bomar, George W.

1983 Texas Weather. University of Texas Press, Austin.

Bousman, C. Britt, Barry W. Baker, and Anne C. Kerr

2004 Paleoindian Archeology in Texas. In The Prehistory of Texas, edited by Timothy K. Perttula, pp. 15-97. Texas A\&M Press, College Station.

Brown, K. M.

2006 Chapter 8: Snails. In The Bench Deposits at Berger Bluff: Early Holocene-Late Pleistocene Depositional and Climate History. Unpublished Ph.D. dissertation, Department of Anthropology, The University of Texas at Austin.

Byers, David A., and Andrew Ugan

2005 Should We Expect Large Game Specialization in the Late Pleistocene? An Optimal Foraging Perspective on Early Paleoindian Prey Choice. Journal of Archaeological Science 32:16241640 .

Campbell, T. N., and T. J. Campbell

1985 Indian Groups Associated with Spanish Missions of the San Antonio Missions National Park. Special Report 16. Center for Archaeological Research, University of Texas at San Antonio. 
Cannon, Michael D., and David J. Meltzer

2004 Early Paleoindian Foraging: Examining the Faunal Evidence for Large Mammal Specialization and Regional Variability in Prey Choice. Quaternary Science Reviews 23:1955-1987.

Coffee, Daniel R.

1967 Soil Survey of Menard County, Texas. United States Department of Agriculture. Soil Conservation Service, Washington, D. C.

Collins, Michael B.

1994 Evidence of Early Archaic Occupation. In Archaic and Late Prehistoric Human Ecology in the Middle Onion Creek Valley, Hays County, Texas, by Robert A. Ricklis and Michael B. Collins, pp. 67-100. Studies in Archeology 19, Texas Archeological Research Laboratory, the University of Texas at Austin, Austin.

1995 Forty Years of Archaeology in Texas. Bulletin of the Texas Archeological Society 66:361400.

2004 Archeology in Central Texas. In The Prehistory of Texas, edited by Timothy K. Perttula, pp. 101-126. Texas A\&M University Press, College Station.

Collins, Michael B. (assembler and editor)

1998 Wilson-Leonard: An 11,000-Year Archeological Record in Central Texas. 6 Vols. Studies in Archeology 31. Texas Archeological Research Laboratory, The University of Texas at Austin. Archeology Studies Program Report 10. Texas Department of Transportation, Environmental Affairs Division, Austin.

Collins, Michael B., and Kenneth M. Brown

2000 The Gault Gisement: Some Preliminary Observations. In Current Archeology in Texas 2(1):163-166.

Cook, Edward R., David M. Meko, David W. Stahle, and Malcom K. Cleavland 1999 Drought Reconstructions for the Continental United States. Journal of Climate 12:1145-1162.

Dahlberg, Frances (editor)

1981 Woman the Gatherer. Yale University Press, New Haven.

Davis, W. B., and D. J. Schmidley

1997 The Mammals of Texas--Online Edition. Texas Tech University. Accessed 22 September 2009. http://www.nsrl.ttu.edu/tmot1/

de la Teja, Jesús F.

1995 San Antonio de Bexar: A Community on New Spain's Northern Frontier. University of New Mexico Press, Albuqueruque. 
Dering, Phil

2008 Late Prehistoric Subsistence Economy on the Edwards Plateau. Plains Anthropologist 53:5977.

Dunn, William E.

1911 Apache Relations in Texas, 1718-1750. Southwestern Historical Quarterly 14:198-274.

Earls, Amy C., and John Leffler

1996 Fort McKavett: Archeological Inve4stigationa for Fort Stabilization and Restoration, Fort McKavett State Historical Park, Menard County, Texas: 1978-1990 Seasons. Reports of Investigations, Number 105. Prewitt \& Associates, Austin.

Ellis, Linda Wootan

1997 Hot Rock Technology. In Hot Rock Cooking on the Greater Edwards Plateau: Four Burned Rock Midden Sites in West Central Texas, Volume 1, by Stephen L. Black, Linda W. Ellis, Darrell G. Creel, and Glenn T. Goode, pp. 43-81. Studies in Archeology 22, Texas Archeological Research Laboratory, The University of Texas at Austin, and Archeological Studies Program, Report 2, Environmental Affairs Division, Texas Department of Transportation, Austin.

Ellis, Linda Wootan, G. Lain Ellis, and Charles D. Frederick

1995 Implications of Environmental Diversity in the Central Texas Archeological Region. Bulletin of the Texas Archeological Society 66:401-426.

Fisher, Lewis F.

1998 The Spanish Missions of San Antonio. Maverick Publishing Company, San Antonio.

Foster, William C.

1995 Spanish Expeditions into Texas 1689-1768. University of Texas Press, Austin.

2008 Historic Native Peoples of Texas. The University of Texas Press, Austin.

Gould, F.W.

1962 Texas Plants-A Checklist and Ecological Summary. The Agricultural and Mechanical College of Texas, Texas Agricultural Experiment Station, College Station.

Green, F.E.

1963 The Clovis Blades: An Important Addition to the Llano Complex. American Antiquity 29:145165.

Habig, Marion A.

1977 The Alamo Mission: San Antonio de Valero, 1718-1793. Franciscan Herald Press, Chicago. 
Hall, Grant D.

1981 Allens Creek: A Study in the Cultural Prehistory of the Lower Brazos River Valley, Texas. Research Report No. 61, Texas Archeological Survey. The University of Texas at Austin.

2000 Pecan Food Potential in Prehistoric North America. Economic Botany 54(1):103-112.

2001 Mission San Sabá. Electronic document http://www.texasbeyondhistory.net/ sansaba/ accessed 13 October, 2009.

Harris, Edwin S.

1985 An Archaeological Study of the Timmeron Rockshelter (41HY95), Hays County, South Central Texas. Special Publication No. 4, South Texas Archeological Association, San Antonio.

Hatcher, Mattie Austin

1927 "Descriptions of the Tejas or Asinai Indians, 1691-1722", Volume 030, Number 4, Southwestern Historical Quarterly Online, pp. 283-304. www.tsha.utexas.edu/ publications/ journals/shq/online/v030/n4/article_6.html.

Hester, Thomas R.

1983 Late Paleo-Indian Occupations at Baker Cave, Southwestern Texas. Bulletin of the Texas Archeological Society 53:101-119.

1995 The Prehistory of South Texas. Bulletin of the Texas Archeological Society 66:427-459.

2004 The Prehistory of South Texas. In The Prehistory of Texas, edited by Timothy Perttula, pp. 127-151. Texas A\&M University Press, College Station.

Hickerson, Nancy Parrott

1994 The Jumanos: Hunters and Traders of the South Plains. The University of Texas Press, Austin.

Hill, Kim, Hillard Kaplan, Kristen Hawkes, and A. Magdalena Hurtado

1985 Foraging Decisions among the Aché Hunter-Gatherers: New Data and Implications for Optimal Foraging Models. Ethology and Sociobiology 8:1-36.

Hindes, V. Kay, Mark R. Wolf, Grant D. Hall, and Kathleen Kirk Gilmore

1995 The Rediscovery of Santa Cruz de San Sabá, a Mission for the Apache in Spanish Texas. San Saba Regional Survey Report 1, Archaeology Laboratory, Texas Tech University, Lubbock.

Hixson, Charles A.

1997 41BC130: A Prehistoric Food Processing Site in Blanco County, Central Texas. The Steward: Collected Papers on Texas Archeology 4:57-70. Texas Historical Commission, Austin.

Houk, Brett A., and Jon C. Lohse

1993 Excavations at the Mingo Site, Bandera County, Texas. Bulletin of the Texas Archeological Society 61:193-247. 
Houk, Brett A., Kevin A. Miller, and Eric R. Oksanen

2009 The Gatlin Site and the Early-to-Middle Archaic Chronology of the Soutehrn Edwards Plateau, Texas. Bulletin of the Texas Archeological Society 80:51-75.

Howells, R.G., R.W. Neck, and H.D. Murray

1996 Freshwater Mussels of Texas. Texas Parks and Wildlife Department Inland Fisheries Division, University of Texas Press, Austin, Texas.

Huebner, Jeffery A.

1991 Late Prehistoric Bison Populations in Central and Southern Texas. Plains Anthropologist 36(137):343-358.

Jelks, Edward B.

1962 The Kyle Site: A Stratified Central Texas Aspect Site in Hill County, Texas. Archeology Series 5:1-115. The University of Texas, Department of Anthropology, Austin.

Johnson, LeRoy, Jr.

1987 A Plague of Phases. Bulletin of the Texas Archeological Society 57:1-26.

1994 The Life and Times of Toyah-Culture Folk: The Buckhollow Encampment, Site 41KM16, Kimble County, Texas. Office of the State Archeologist Report 38. Texas Department of Transportation and Texas Historical Commission, Austin.

Johnson, Leroy, and Thomas N. Campbell

1992 Sanan: Traces of a Previously Unknown Aboriginal Language in Colonial Coahuila and Texas. Plains Anthropologist 37(140):185-212.

Johnson, LeRoy, and Glenn T. Goode

1994 A New Try at Dating and Characterizing Holocene Climates, as Well as Archeological Periods, on the Eastern Edwards Plateau. Bulletin of the Texas Archeological Society 65:1-51.

Kelley, J. Charles

1947 The Lehmann Rock Shelter: A Stratified Site of the Toyah, Uvalde, and Round Rock Foci. Bulletin of the Texas Archeological and Paleontological Society 18:115-128.

1955 Juan Sabeata and Diffusion in Aboriginal Texas. American Anthropologist 57:981-995.

Kenmotsu, Nancy Adele

1994 Helping Each Other Out: a Study of the Mutualistic Relations of Small Scale Foragers and Cultivators in La Junta de los Rios Region, Texas and Mexico. Unpublished Ph.D. dissertation, Department of Anthropology, The University of Texas at Austin.

Krieger, Alex D.

2002 We Came Naked and Barefoot: The Journey of Cabeza de Vaca across North America. The University of Texas Press, Austin. 
Larsen, C., S.

1997 Bioarchaeology: Interpreting Behavior from the Human Skeleton. Cambridge University Press, Cambridge.

Lee, Richard B., and Irven DeVore (editors)

1968 Man the Hunter. Aldine Publishing Company, Chicago.

Lemke, Ashley, and Cinda Timperley

2008 Preliminary Analysis of Turtle Material from the Gault Site, Texas. Current Research in the Pleistocene 25:115-117.

Lohse, Jon C.

2009 Toward Understanding Embedded Specialization in Hunter-Gatherer Societies. Paper presented at the 80th Annual Meeting of the Texas Archeological Society, Del Rio.

2010 Prehistoric Life, Labor, and Residence in Southeast-Central Texas: Results of Data Recovery at 41HY163, the Zatopec Site, San Marcos, Texas, edited by Jon C. Lohse. Texas Antiquities Permit No. 4569. Forthcoming.

Mauldin, Raymond P., Jennifer Thompson, and Leonard Kemp

2009 Reconsidering the Role of Bison in the Terminal Late Prehistoric (Toyah) Period in Texas. For inclusion in Revisiting the Late Prehistoric in Central Texas: The Toyah Phase, edited by Nancy Kenmotsu and Doug Boyd. Plains Anthropologist Memoir.

McGraw, A. Joachim, John W. Clark, Jr., and Elizabeth A. Robbins (editors)

1991 A Texas Legacy: the Old San Antonio Road and the Caminoes Reales: a Tricentennial History, 1691-1991. State Department of Highways and Public Transportation, Highway Design Division, Austin.

McWilliams, Jennifer K., and Douglas K. Boyd

2008 Historical Assessment and Archeological Survey of 4.9 Miles of FM 2092 from Menard to Five Mile Crossing, Menard County, Texas. Texas Department of Transportation Environmental Affairs Division, Archeological Studies Program, Report No. 103, and Reports of Investigations, Number 155, Prewitt \& Associates, Inc., Austin.

Meagher, $\mathrm{M}$.

1986 Bison bison. Mammalian Species 266:1-8.

Miller, Mason, James W. Karbula, and Jonathan Jarvis

2003 Archeological Survey for US 83 Junction to Menard in Menard and Kimble Counties, Texas. Hicks \& Company Archeology Series No. 125, Austin.

Murdock, George P., and Caterina Provost

1973 Factors in the Division of Labor by Sex: A Cross-Cultural Analysis. Ethnology 12:203-225. 
Newcombe, Jr., W. W.

1993 Historic Indians of Central Texas. Bulletin of the Texas Archeological Society 64:1-63.

1999 The Indians of Texas from Prehistoric to Modern Times. Originally published 1961. The University of Texas Press, Austin.

Ogilvie, Marsha D.

2005 A Biological Reconstruction of Mobility Patterns in Late Archaic Populations. In The Late Archaic across the Borderlands: From Foraging to Farming, edited by Bradley J. Vierra, pp. 84-112. University of Texas Press, Austin.

Prewitt, Elton R.

1974 Archeological Investigations at the Loeve-Fox Site, Williams County, Texas. Research Report 49. Texas Archeological Survey, The University of Texas at Austin.

1981 Culture Chronology in Central Texas. Bulletin of the Texas Archeological Society 52:65-89.

1983 From Circleville to Toyah: Comments on Central Texas Chronology. Bulletin of the Texas Archeological Society 54:210-238.

Quigg, J. Michael, Mary E. Malainey, Roman Przybylski, and Gregory Monks

2001 No Bones about It: Using Lipid Analysis of Burned Rock and Groundstone Residues to Examine Late Archaic Subsistence Practices in South Texas. Plains Anthropologist 46(177):283-303.

Qugg, J. Michael, Jeffery D. Owens, Paul M. Matchen, Grant D. Smith, Robert A. Ricklis, Mercedes C. Cody, and Charles D. Frederick

2008 The Varga Site: A Multicomponent, Stratified Campsite in the Canyonlands of Edwards County, Texas, Volume 1. Technical Report No. 35319, TRC Environmental Corporation, and Archeological Studies Program Report No. 110, Texas Department of Transportation, Environmental Affairs Division, Austin.

Riemenschneider, Larry

1994 Boat-Shaped Bedrock Mortars in Reagan County, Texas. La Tierra 21:3-5.

Riemenschneider, Larry, and Solveig A. Turpin

1998 Boat-Shaped Bedrock Mortars in Crockett County, Texas. La Tierra 25:36-41.

Ricklis, Robert A.

1994 Toyah Components: Evidence for Occupations in the Project Area during the Latter Part of the Late Prehistoric Period. In Archaic and Late Prehistoric Human Ecology in the Middle Onion Creek Valley, Hays County, Texas, by Robert A. Ricklis and Michael B. Collins, pp. 207-316. Studies in Archeology 19, Texas Archeological Research Laboratory, the University of Texas at Austin, Austin. 
Saner, Bryant, Jr., and Chuck Hixson

1999 Ancient Bedrock Mortars at Smith Ranch. The Steward: Collected Papers on Texas Archeology 5:3-26. Texas Historical Commission, Austin.

Shafer, Harry J., and Jim Zintgraff

1986 Ancient Texans: Rock Art and Lifeways along the Lower Pecos. Texas Monthly Press, Austin.

Sassaman, Kenneth E.

1992 Lithic Technology and the Hunter-Gatherer Sexual Division of Labor. North American Archeologist 13:249-262.

Spector, Janet

1998 Male/Female Task Differentiation among the Hidatsa: Toward the Development of an Archaeological Approach to the Study of Gender. In Reader in Gender Archaeology, edited by Kelley Hays-Gilpin and David S. Whitley, pp. 145-158. Routledge Press, New York.

Spielmann, Katherine A. (editor)

1991 Farmers, Hunters, and Colonists: Interaction Between the Southwest and the Southern Plains. University of Arizona Press, Tucson.

Story, Dee Ann

1985 Adaptive Strategies of Archaic Cultures of the West Gulf Coastal Plain. In Prehistoric Food Production in North America, edited by Richard I. Ford, pp. 19-56. Anthropological Papers No. 75. Museum of Anthropology, University of Michigan, Ann Arbor.

Taylor, Anna Jean

1995 Summary and Consideration of Cultural Features. In Archeological Investigations at the Loma Sandia Site (41LK28): A Prehistoric Cemetery and Campsite in Live Oak County, Texas. Volume 1, by Anna Jean Taylor and Cheryl Lynn Highley, pp. 359-404. Studies in Archeology 20, Texas Archeological Research Laboratory, The University of Texas at Austin.

Texas Beyond History

2001 Fort McKavett and Hill Country Frontier. www.texasbeyondhistory.net /forts/mckavett/ index.html. Electronic document accessed 14 October, 2009.

Thoms, Alston V., and Rolfe D. Mandel (editors)

2007 Archaeological and Paleoecological Investigations at the Richard Beene Site, SouthCentral Texas. Reports of Investigations 8, Center for Ecological Archaeology, Texas A\&M University, College Station.

Turner, Ellen Sue, and Thomas R. Hester

1993 A Field Guide to Stone Artifacts of Texas Indians. Second edition. Gulf Publishing Company, Houston. 
Tyler, Ron (editor)

1996 The New Handbook of Texas. Six Volumes. Texas State Historical Association, Austin.

Wade, Mariah F.

2003 The Native Americans of the Texas Edwards Plateau, 1582-1799. The University of Texas Press, Austin.

Waguespack, Nicole M.

2005 The Organization of Male and Female Labor in Foraging Societies: Implications for Early Paleoindian Archaeology. American Anthropologist 107:666-676.

Waguespack, Nicole M., and Todd A. Surovell

2003 Clovis Hunting Strategies, or How to Make out on Plentiful Resources. American Antiquity 68:333-352.

Walter, Tamra L., Elizabeth A. Cooper, Nancy Zayatz, and Grant D. Hall

2003 Ruin of Ruins: Archaeological Excavations at Presidio San Sabá, 41MN1, Menard County, Texas, 2000-2002 Field Seasons. San Saba Regional Survey Report 2, Archaeology Laboratory, Texas Tech University, Lubbock.

Weir, Frank A.

1976 The Central Texas Archaic. Unpublished Ph.D. dissertation, Anthropology Department, Washington State University, Pullman.

Wintes, Howard D.

1974 Indian Knoll: Introduction to the New Edition, by William S. Webb, pp. v-xxvii. Originally published 1946. The University of Tennessee Press, Knoxville.

Wyckoff, Don G.

1994 Recognizing the Calf Creek Horizon: Background and Some Problems. In Bulletin of the Oklahoma Anthropological Society, Volume XL for 1991, pp. 1-8. Oklahoma Anthropological Society, Norman. 